Portland State University

PDXScholar

1978

\title{
A Comparative Study of the Resettlement Status of Indochinese Refugees in Portland
}

\author{
Rosalynn R. Ringor \\ Portland State University \\ Chareundi Van-Si \\ Portland State University \\ Steven Hernandez \\ Portland State University
}

Follow this and additional works at: https://pdxscholar.library.pdx.edu/open_access_etds

Part of the Demography, Population, and Ecology Commons, History Commons, and the Social Work Commons

Let us know how access to this document benefits you.

\section{Recommended Citation}

Ringor, Rosalynn R.; Van-Si, Chareundi; and Hernandez, Steven, "A Comparative Study of the Resettlement Status of Indochinese Refugees in Portland" (1978). Dissertations and Theses. Paper 2756.

https://doi.org/10.15760/etd.2744

This Thesis is brought to you for free and open access. It has been accepted for inclusion in Dissertations and Theses by an authorized administrator of PDXScholar. Please contact us if we can make this document more accessible: pdxscholar@pdx.edu. 
A COMPARATIVE STUDY OF THE RESETTIEMENT STATUS OF INDOCHINESE REFUGEES IN PORTLAND

by

ROSALYNN R. RINGOR

CHAREUNDI VAMN-SI

STEVEN HERNANDEZ

A practicum submitted in partial fulfillment of the requirements for the degree of

MASTER OF SOCIAL WORK

Portland State Universicy

1978

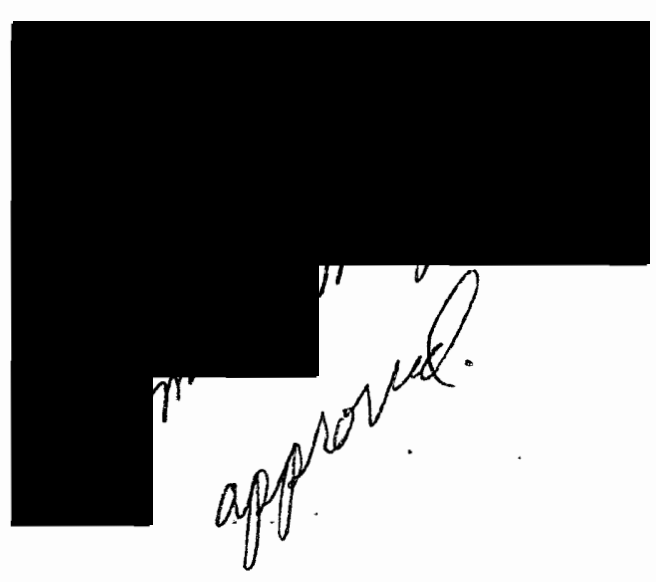




\section{ACKNOWLEDGMENTS}

We wish to express our appreciation to many people for their interest, encouragement, and assistance in the development of this project. We especially wish to thank the following: Jerry Burns, Kurt Fiese1, and Jean Immel of the HEW Indochinese Refugee Program, Salem, Oregon, for their valuable assistance in the development stages of the project; the Portland Indochinese Cultural and Service Center staff for their help in sample construction, questionnaire development, and translations; the ESL (English-as-a-Second-language) instructors and staff at Portland Community College and Portland State University for their part in the preliminary phase survey; and countless others; and finally, a special thanks to the Indochinese refugees in Portland who shared their thoughts and feelings with us. 
TABLE OF LONTENTS

PAGE

ACKNOWLEDGMENTS . . . . . . . . . . . . . . . . . .

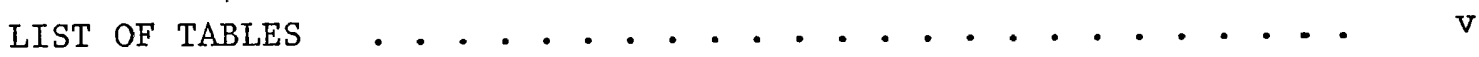

CHAPTER

I PURPOSE AND OVERVIEW . . . . . . . . . . . 1

II REVIEW OF THE LITERATURE . . . . . . . . . 5

Historical Perspectives ......... . . 6

Immigrants, Refugees, and Assimilation Theory. • 7

Special Assimilation Problems of Refugees ... 10

Social Services ........... 13

III RESEARCH DESIGN AND EXECUTION . . . . . . . . 40

Population . . . . . . . . . . . 40

Sampling Information......... 40

Data Collection Methods . . . . . . . 42

Development of the Questionnaires ..... 43

Some Variables and Possible Influences to Resettlement . . . . . . . . 44

Questionnaire Translations ........ 46

Distribution of the Questionnaires and Response Rates ............. 46

Data Tabulation and Analysis . . . . . . 47

IV FINDINGS .................... 50

Preliminary Phase . . . . . . 50 
CHAPTER

PAGE

Major Phase . : . . . . . . . . . . .

Statistical Analyses . . . . . . . . .

V . SUMMARY $\triangle N D$ CONCLUSIONS . . . . . . . . . .

Preliminary Phase . . . . . . . . . . . .

Major Phase . . . . . . . . . . . .

Further Research . . . . . . . . . .

VI COMMENTS

APPENDIX B: MAJOR PHASE TABULATED DATA . . . . . . . . . 100 
I Items/Goals Considered Most Important to Successful Resettlement by $50 \%$ of the Total Average of Indochinese Refugees . . . . . . . . . . . .

II Items/Goals Considered Least Important to Successful Resettlement by $20 \%$ of the Total Average of Indochinese Refugees . . . . . . . . . . . . .

III Percentage Distribution of Indochinese Responses to Barrier Conditions to Successful Resettlement. . . .

IV Distribution by Ages of Successful and Unsuccessful Refugees . . . . . . . . . . . . 54

V Distribution of Respondents' Sex by Ethnic Group . . . . 54

VI Distribution of Marital Status Among Successful and Unsuccessful Refugees . . . . . . . . . .

VII Range of Former Occupations Among Successful and Unsuccessful Refugees . . . . . . . . . . .

VIII Distribution of English Reading Ability Among Successful and Unsuccessful Refugees . . . . . . . . . .

IX Distribution of English Speaking Ability Among Successful and Unsuccessful Refugees . . . . . . . . . .

$X$ Distribution of Length of Stay in America Among Successful and Unsuccessful Refugees . . . . . . . .

XI Desire to Return Home Among Successful and Unsuccessful Refugees . . . . . . . . . . . . . .

XII Distribution of Successful and Unsuccessful Refugees Who Do or Do Not Own a Home . . . . . . . . 100

XIII Distribution of Successful and Unsuccessful Refugees Who Do or Do Not Live with their Families . . . 100

XIV Distribution of Successful and Unsuccessful Refugees Who Do or Do Not Own a Car . . . . . . . . . . . 
XV Distribution of Successful and Unsuccessful Refugees Who Do or Do Not Have a Driver's License . . . . . . 101

XVI Distribution of Successful and Unsuccessful Refugees tho Do or Do Not Have a Job . . . . . . . . . . 101

XVII Distribution of Successful and Unsuccessful Refugees Who Do or Do Not Have a Job Suiting their Education and Skills................. 101

XVIII Distribution of Successful and Unsuccessful Refugees Who Do or Do Not Have Recertified Degrees . . . . . 102

XIX Distribution of Successful and Unsuccessful Refugees Who Have or Have Not Had Job Training . . . . . . . 102

XX Distribution of Successful and Unsuccessful Refugees Who Have or Have Not Had ESL Training . . . . . . 102

XXI Distribution of Successful and Unsuccessful Refugees Who Do or Do Not Have American Friends . . . . . . 103

XXII Distribution of Successful and Unsuccessful Refugees Who Do or Do Not Practice their Religion . . . . . 103

XXIII Distribution of Successful and Unsuccessful Refugees Who Do or Do Not Participate in Cultural Activities . . . 103

XXIV Distribution of Successful and Unsuccessful Refugees Who Do or Do Not Have Bank Accounts . . . . . . . . 104

XXV Distribution of Successful and Unsuccessful Refugees Who Do or Do Not Have Health Insurance . . . . . . 104

XXVI Distribution of Successful and Unsuccessful Refugees Who Do or Do Not Have Auto Insurance . . . . . . . . 104

XXVII Distribution of Successful and Unsuccessful Refugees Who Do or Do Not Have Access to Medical Services . . . . 105

XXVIII Distribution of Successful and Unsuccessful Refugees Who Do or Do Not Participate in Recreation Activities . . 105

XXIX Distribution of Successful and Unsuccessful Refugees Who Have or Have Not Applied for Permanent Residency . . 105

XXX Distribution of Successful and Unsuccessful Refugees tho Are or Are Not Willing to Americanize their Names . 106 
XXXI Distribution of Successful and Unsuccessful Refugees Who Do or Do Not Know. Where to go for Medical/Health Problems . . . . . . . . . . . . . . 107

XXXII Distribution of Successful and Unsuccessful Refugees Who Do or Do Not know where to go for Race Discrimination Problems ............... 107

XXXIII Distribution of Successful and Unsuccessful Refugees Who Do or Do Not Know Where to go for Marriage Problems .

XXXIV Distribution of Successful and Unsuccessful Refugees Who Do or Do Not know Where to go for Welfare Problems . 108

XXXV. Distribution of Successful and Unsuccessful Refugees Who Do or Do Not know Where to go for Employment Problems ................. . 108

XXXVI Distribution of Successful and Unsuccessful Refugees Who Do or Do Not know Where to go for Political Problems . . . . . . . . . . . . . . . . . .

XXXVII Distribution of Successful and Unsuccessful Refugees Who Do or Do Not know where to go for School Problems

XXXVIII Distribution of Successful and Unsuccessful Refugees Who Feel Social Service Workers Understand Their Problems and Hëlp Them............. 109

XXXIX Distribution of Successful and Unsuccessful Refugees who Feel Social Service Workers Treat Them Respectfully

XI Distribution of Successful and Unsuccessful Refugees Who Feel They Don't Have to Wait Too Long for Services

XII Distribution of Successful and Unsuccessful Refugees Who Have Found Places to Live Via Social Service Agencies 110

XLII Distribution of Successful and Unsuccessful Refugees Who Have Found Jobs Via Social Service Agencies . . . . 110

XLIII Distribution of Successful and Unsuccessful Refugees Who Have or Have Not Encountered Language and Communication Problems with Social Agencies . . . . . . . . 111

XLIV Distribution of Successful and Unsuccessful Refugees who Have Encountered Cultural Misunderstandings With Social Service Agencies . . . . . . . . . . . . 
XIV Distribution of Successful and Unsuccessful Refugees Who Have Encountered. Other Problems With Social

Service Agencies : . . . . . . . . . . . 111

XLVI Distribution of Successful and Unsuccessful Refugees Who Feel Racial Discrimination Has Affected Their Resettlement . . . . . . . . . . . 112

XLVII Distribution of SuccessfuI and Unsuccessful Refugees Who Feel They Have Come Up Against Pressure in Taking a Job . . . . . . . . . . . . . . 112

XLVIII Distribution of Successful and Unsuccessful Refugees Who Feel They Have Attained Success in Their New Life 


\section{CHAPTER I}

PURPOSE AND OVERVIEW

This study sought to explore the resettlement of Indochinese refugees to their new life in Portland, Oregon. Three basic areas were under consideration. The first area dealt with demographic data: who are the refugees and what are their pasts? The second area focused on aspects of successful resettlement: what do refugees seek in order to consider themselves successfully resettled, and how do their ideas of successful resettlement collate with their present state of resettlement? The third area dealt with the effectiveness of resettlement programs: how have various assistance programs been helpful to the refugees, and are the refugees aware of the community's sociai services resources?

Approximately 2400 Indochinese refugees have settled in the Portland area - 1650 Vietnamese, 480 Cambodians, and 265 Laotians. They began arriving in May, 1975, with the majority arriving during the following summer and fall. Of the 2400 people in the area, a large percentage are children.

Man's story is, in large measure, the story of his wanderings. Throughout recorded history, invasions, wars, and conquests were followed by large-scale movements of populations. Migrations in early modern nistory include the Moors and the Jews as they fled from Spain, the Huguenot refugees in 16 th century France, and some of the early English settlers in America, and many, many more. 1

Throughout its history, the United States has played a role as a 
melting pot of immigrants and refugees. In recent history, refugees from countries falling under Communist rule have been welcomed by Americans. Examples include the Hungarian refugees of the post World War II era, the Cuban refugees after Castro's takeover, and the European migrants fleeing Europe as the Iron Curtain fell. In recent years, Indochinese refugees have migrated. to the United States, coming mainly from the countries of Vietnam, ,-Cambodia, - and - Laas.

The plight of refugees in this country is an uncertain one. There are no consistent, standard policies which guide social service agencies in working and assisting refugee groups as they enter the country. Specific legislation is enacted, on state and federal levels, whenever a specific refugee group enters the country and whenever the need is demonstrated. The majority of the Indochinese refugees first came to this country under the auspices of sponsor organizations and voluntary agencies based in the various receiving states. These organizations and agencies, such as the U.S. Catholic Conference, Church World Service, the Lutheran Immigration and Refugee Service, the Hebrew Immigration and Aid Society, and nondenominational agencies such as the International Rescue Committee, the Tolstoy Foundation, etc., having experience with immigrants, relocated the refugees throughout the country. Refugee camps were set up, with Camp Pendieton in California and Englin Air Force Base in Florida being the two largest camps. ${ }^{2}$

Only two of the nine agencies which arranged"sponsorship for the refugees have offices in Portland. These are the U.S. Catholic Conference and the Lutheran Immigration and Refugee Service. Most of the refugees in the Portland area came under the auspices of these two agencies. However, refugees sponsored through other agencies also reside in the 
area .

The Indochinese Migration and Refugee Assistance Act of 1975 made it possible for Indochinese refugees in the United States to receive pub1ic assistance. This assistance ended in September, 1977. In most states where refugees were resettled, the sponsor organizations and voluntary agencies, with federal assistance, provided the major support in assisting the refugees and have continued to do so. The state of Oregon, however, is in a different situation. The major support for assisting Indochinese refugees in Oregon originated from the state level, with a mjor portion of refugees having been on public assistance at one time or another. The role of sponsors and voluntary agencies in Oregon has not been lessened, however. They continue to support and assist refugees in resettling in the state.

Indochinese refugees appear to be in a guandary. From a review of current literature and previous research on imnigrants and refugees, we can construct a better understanding of the Indochinese refugees' situation in our society. 
NOTES

1 John Stoessinger, "Refugees," Encyclopaedia Brittanica, 1973 ed.

2 Galen Beery, "Special Report, Indochina Refugees: Resettlement Progress," The Christian Century, October 1976, p. 931. 
Literature on refugees and immigrants was surveyed in order to gain an overall picture of these populations as they resettled and adjusted into a different culture and society.

An overview of the problem of the "refugee," or the "man without a country," according to Tatiana Schaufuss requires a thorough understanding of the sociological and psychological factors which created this problem, together with sufficient information which deals with its historical and present aspects. 1

Despite common characteristics, Indochinese reftrgees differ according to their"historical, ethnic, religious and social customs. They come from closely knit societies and retain autonomy in differentiated areas of resettlement in their new country. There is a diverse range of occupational backgrounds among the refugees. Educational levels are also dit verse, with approximately 50 percent of the heads of households having, at least, a secondary school education and 25 percent having college educations. ${ }^{2}$

The Indochinese came into lands occupied by other cultural groups. Many came, according to Francis Brown, seeking new opportunities for themselves and their children, and because they feared political persecution in their homeland. ${ }^{3}$ Minority groups have Elourished in every state, but problems of the Indochinese refugees are only recent. 


\section{HISTORICAL PERSPECTIVES}

\section{Land of Indochina}

The land of Indochina - Vietnam, Cambodia, and Laos - - was controlled by French colonialists from 1893 to 1954. During this period, continuous hostilities against French rule produced refugee problems within the country. 4 The three nations, through much struggle and hardship, gained their independence from France almost simultaneously. Vietnam has been independent since 1953. And, according to Geneva agreements, was divided into two sections, north and south.

After the acquisition of Indochinese independence, pro-western governments came in, held power, and influenced the newly-independent nations. As a result, nationalist movements were formed: the Viet Cong in Vietnam, the Khmer Rouge in Cambodia, and the Pathet Laof in Laos. With the support of North Vietnam and China, these movements launched campaigns and attacks on the pro-western influences. 5

\section{The Fall of Indochina: Refugee Migration}

In the spring of 1975, the land of Indochina fell into communism. 6 Cambodia fell on April 17, 1975; Vietnam on April 30, 1975. Laos was the last to fall into commism. The political takeover in Laos was not so overpowering as in the other two countries since a coalition government managed to ease the tension of the people. This made the transition to communism less abrupt and violent. Thousands of right-wing officials and soldiers of the old government, merchants and middle-class Lactians began fleeing the country across the border into Thailand in mid-May, 1975 . The flight accelerated after the communist victory at the end of $1975 .^{7}$ 
The collapse of Vietnam and Cambodia was so sudden that refugees were stranded in camps. These people were, for the most part, those who had close association with Americhans or those who were bitter personal or political foes of the communists. The vast majority of these refugees had little time to decide whether to stay or to leave the country. 8

Most of the Vietnamese and Cambodian refugees were eventually sponsored and assisted with such needs as food, shelter, employment, language skills, and moral support. The Laotians, on the other hand, who were the late-comers, were virtually neglested. Sponsors were difficult to procure. Many factors contributed to this state of affairs. The United States, for on thing, was in the midst of the 1976 recession. It was also a Presidential election year. At this time, the bad memories of the Indochinese war faded away from American public and political minds; and the Vietnamese and Cambodians seemed to have pre-empted American attention and goodwill, as well as any available employment opportunities.

While 150,000 Indochinese refugees were-resettled in America, some 80,000 others remainet in the camps in Thailand. The majority of these people were from Laos. In July, 1977, the White House approved the resettlement of 15,000 more refugees; 7,000 of these were boat cases. 9

\section{IMMIGRANTS, REFUGEES, AND ASSTMILATION THEORY}

The literature indicates that the movement of a person from one society and cuiture to another society and culture involves a drastic change in that person's life pattern. A number of terms have been used to describe the process through which societal and cultural differences among individuals and groups are gradually reduced to a common culture and varied behavior patterns are fused into a social unity. Among the 
terms used to describe this process have been "assimilation," "integration," and "absorption." Much theoretical confusion has been generated in the study of this process by the use of overlapping terms and vaguely defined concepts.

Milton Gordon, in Assimilation in American Life, called for the rigorous and systematic analysis of the concept of assimilation that would break it down to all its component aspects. He notes that two major aspects of this concept are cultural assimilation and structural assimilation. Cultural assimilation refers to the change of cultural patterns those of the host society, structural assimilation to the large-scale entrance of imigrants into the primary group life of the host society. According to Gordon, cultural assimilation can be called absorption and structural assimilation, integration. 10

Eleanor Rogg comments that in a society of large-scale immigration, such as the United States, the situation is not one in which immigrants are forced into the mold of the original Anglo-Saxon settlers. Nor are immigrants absorbed into one great melting pot and cooked up as homogenized Americans. Instead, a structurally plural network of ethnic and other groupings emerged. In such a society, cultural assimilation can occur rapidly, but structural assimilation tends to be slow. ${ }^{11}$

According to Rogg, two main indices have been used historically to measure cultural assimilation: acculturation and personal adjustment. Acculturation measures the extent to which the immigrant has learned the norms, roles, and customs of the absorbing society, as well as how effectively he has internalized them. Personal adjustment measures the individual's contentment with the new country, his ability to handle the many new difficulties and frustrations he faces in daily living in a new physi- 
cal and social environment.

The immigrant arrives in his new country with various images and expectations about future roles and indentifications. S. Eisenstadt in The Absorption of Immigrants, sees four phases in the process of the immigrant's institutionalization of role expectations. ${ }^{12}$ First, the migrant must acquire various skills. He must learn to make use of the society's language, technical opportunities, and ecological orientations. Second, he must perform many new roles. Third, he must rebuild his idea of himself and his status-image by acquiring new values and by trying them out in relation to the new roles required of him. Finally, he must extend his participation in society away from exclusive participation in his migratory primary group into other spheres of the larger social system of his new country. Milton Gordon believes that this final stage, called structural assimilation, is rarely attained by first-generation immigrants, particularly immigrants of peasant, working-class, and lower-middle-class backgrounds. 13

In a study of premigration traits related to immigrant assimilation, Jerold Heiss found that migrants who have shown some degree of ability and drive during their early adulthood; those who were socially mobile, were more likely to become assimilated. ${ }^{14}$ Youth at the time of migration and family support for migration also seem to favor assimilation.

James Vander Zanden, in American Minority Relations, states, "the higher the educational, income and occupational levels of the incoming group, the more rapid the assimilation....similarly, groups at higher educational, income and occupational levels tend to have greater access to the means for upward mobility, which in turn tend to be associated with a higher rate of assimilation." 15 
Milton Gordon theorizes that, "people of different social classes tend to act differently and have different values even if they have the same ethnic background." 16

The literature indicates that immigrants will assimilate more readily to a similar class position in the host society. ${ }^{17}$ There is a positive relationship between acculturation and social mobility in the United States. The immigrants who have high social status are the most acculturated; the most acculturated tend to have high social status. ${ }^{18}$

SPECIAL ASSIMILATION PROBLEMS OF REFUGEES

If the immigrant is not positively motivated to emigrate from his homeland, Iiterature indicates it will be more difficult for him to accept changes in his customary ways of behaving in the host society. This is the case with refugees - people often torn against their will from their homelands. 19

Historically, immigrants to America have tended to be young persons from lower class origins who were attracted to the shores of this country by the lure of greater wealth. Refugees, on the other hand, tend to come from all age groups and class levels. Most are formerly middle and upper middle class members of their homeland who leave behind many material assets. They are usually hopeful that their stay in their host societies will only be temporary; they anticipate a return to their homelands and don't concern themselves with adjusting to a new way of life in their host countries. 20

Resettled refugees gererally enter the occupational ladder at a significantly lower level than the rung from which they left. Most refugees, in order to resettle, will accept any kind of work. However, as Joseph 
Sechectman points out, signs of dissatisfaction over not using their skills, and over the realization of their loss of status, may begin to appear among them. ${ }^{21}$ Former professionals find they are not able to re-establish themselves immediately; they need to pass various exams and obtain licenses. H. Murphy, in Flight and Resettlement, notes that sometimes the professional requirements of the two countries are so dissimilar that the immigrant is forced to give up his life's work and begin anew. 22

Education and age are major factors related to regaining lost occupational and class status. Murphy indicates that among the educated, the younger regain their former status most rapidly. ${ }^{23}$ Among the less educated, only a few regain their former status regardiess of age. The literature, in general, views education as the most effective factor accelerating assimilation. Raymond Breton and Maurice Pinard note that education affects both the extent to which immigrants establish contacts outside their own group, and the rate at which outside contacts are made. ${ }^{24}$ Another special problem of refugees concerns the emotional trauma of their migration and its effect on their assimilation. In a study of Hungarian refugees, S. Alexander Weinstock found that refugees who were most affected by the Communist takeover in Hungary, those who themselves or whose relatives suffered in some way, acculturated most rapidly. According to Weinstock, among refugees, "catastrophic misfortune acted to sharpen their aggression and to increase their resourcefulness, that rejection and dispossession created in them a burning desire to make a place for themselves and to prove their worth." 25

Mental and emotional illness among refugees was another special problem indicated by the literature. Henry P. David comments that "a predic- 
table percentage of refugees do become psychological casualties, engaging in anxiety-reducing behavior that may range from anti-social acting out to withdrawal into psychosis.... later attempts to change behvior patterns may be far more difficult to implement. "26 other studies and case reports among various refugee groups since the end of World War II support this statement. L. Eitinger, in studies of refugees in Norway, reported that refugees showed great somatic over-concern and high incidences of somatic complaints. 27 Naditch and Morrissey, in a study of Cuban refugees, found a generally high rate of psychopathological symptoms. 28

In studies conducted on Indochinese populations, similar findings were reported. Lin, Tazuma, and Masuda find that Vietnamese refugees have witnessed feelings of homesickness, grief over the losses incurred during the process of evacuation or fleeing, uncertainty about the future, and endless incidents of frustration. 29 They have also observed many Vietnamese suffering from various forms of psychosomatic symptoms accompanying general feelings of nervousness and sadness.

Many Indochinese have been victims of cultural shock -- the cultural and social changes involved in their abrupt uprooting that often accompany a transition from a rural, relatively slow-paced way of life to an urbanized, fast-paced, and competitive society. Depression and mental dysfunctions have befallen many who left families, relatives, friends, fortunes, and traditions in their native lands. 30

In Paris, an observation made Edith Lenart, after a number of visits to the Refugee Centers, was that Vietnamese, Cambodians, and Laotians tend to react quite differently to the problems of readjustment. 31 A Vietnamese, for example, tends to face up to the new challenge and feels confident that he can cope. The Cambodian tends to find it hard and more dif- 
ficult to confront the unfamiliar and his natural reactions is to turn inward upon himself. The Laotian prefers to ignore the challenge and tries to live from day to day. The Muong people, a Laotian tribal group, suffer the most and object to all forms of restriction.

The Report of the Uncle Counselor, a Los Angeles-based Southeast Asian Mental Health Project, found that refugees initially became dependent on their American sponsors for the satisfaction of basic needs, and they later rebelled against accepting their sponsors' authority and guidance in the attempt to fulfill their own needs for social acceptance and self-respect, and to take charge of their own destinies. ${ }^{32}$ To gain independence, refugees moved to apartments and began living on welfare. The situation bred family disruption, loss of social identity, and major shifts in value systems and behavior patterns. ${ }^{33}$

The treatment of depression and other mental health problems of the refugees through conventional western therapy was usually ineffective because of language and cultural factors. To meet these special mental health needs, bilingual paraprofessionals were trained. ${ }^{34}$

Thus, the resettlement process has proven difficult for a majority of the Indochinese refugees as they are not prepared to challienge the fast-paced way of life in a competitive society. Psychosocial problems are observed among immigrants and refugees in the process of assimilating, acculturating, or adapting to American culture. The following sections will explain the variety of social services instituted by public and private agencies to help Indochinese refugees adjust to American life.

SOCIAI SERVICES

On April 29, 1975 the United States embassy in Saigon closed.... 
simultaneously in California, the Camp Pendleton refugee center opened and made ready to care for 1800 refugees. These two acts set in motion the eventual immigration and resettlement of some 145,700 Indochinese refugees into America. ${ }^{35}$ The resettlement effort compelled coordination on the part of numerous American governmental and private agencies and the eventual appropriation of $\$ 555,277,454 .^{36}$ The services subsequently extended the refugees were many, varied, and were intended to facilitate speedy refugee resettlement. What follows is a general description of the social services referred to above and the respective part they played in the resettlement cost.

Health, Education, and Welfare (HEW) Task Force

The HEW Refugee Task Force assumed responsibility for refugee domestic resettlement. Thirty-five members spoke Indochinese languages, six work out of the Washington office; 29 are at ten regional offices of The Department of HEW.

\section{Washington}

The Task Force main office in Washington. D.C. had four operational components concerned with resettlement liaison, information, and referral, Indochinese mutual assistance, and publications.

In the resettlement liaison division, communication with both national and local offices of the voluntary state, and local resettlement agencies was maintained throughout the resettlement process. This division dealt with problems such as social security numbers for additional refugees, samples of "unaccompanied" refugee children, needs of the H'mong refugees, and other problems. 
In the information and referral unit a toll free "hotline" telephone service was maintained for refugees throughout the country. Information was provided also to the general public, Congress, federal, state and local government welfare agencies and voluntary agencies (volags).

The Indochinese mutual assistance association division identified and developed a roster of Indochinese mutual assistance associations to determine the quality of resettlement as a whole and to lend perspective to the role of the associations in the refugee community.

Publications division: The newspaper NEW LIFE was printed in three editions; a monthly Vietnamese-English edition and in alternate months, a Lao-English or a Cambodian-English edition. Articles in NEW LIFE were aimed at providing information on various aspects of American life, government, the employment outlook, and monthly summary of the news media coverage of events in Vietnam, Laos, and Cambodia. Other articles in NEW LIFE dealt with subjects such as training availability, salary ranges, future employment predictions, geographical patterns of job openings, property insurance, coping with winters in the United States, income tax information, glossaries, and orientation hand books, also, home buying and renting, the operation of the government, among others. ${ }^{37}$

\section{Reception Centers}

1. Fort Chaffee, Arkansas

2. Indiantown Gap, Pennsylvania

3. Camp Pendleton, California

4. Elgin Air Force Base, Florida

The reception centers were utilized to introduce Indochinese refugees into the United States. HEW was quick to add, though, that this was 
done expediently, yet ensuring stable resettlement and reducing the possibility that the refugees might become public charges. The stated goal as early as the opening of the reception centers was to make the refugees "supporting" members of their communities.

The following procedures were, for the most part, followed by all the reception centers. The elements were: (A) reception, (B) immigration and naturalization service in-procession, (C) issuance of social security numbers, (D) HEW and social service counseling, (F) internalization and naturalization service (INS) final processing (security check verification), and $(G)$ final out processing and travel. 38

\section{Voluntary Agencies (Volags)}

The government contracted with the following 10 volags to resettle Indochinese refugees in the United States: U.S. Catholic Conference, American Council for Nationalities Service, American Fund for Czechoslovak Refugees, Church World Service, International Rescue Comittee, Lutheran Immigration and Refugee Service, United HIAS Service, Inc., Tolstoy Foundation, Inc., Travelers Aid-International Social Services, and Chinese Consolidated Benevolent Association.

Each of the 10 agencies worked in its own way to mobilize local community resources. to generate sponsors for Indochinese families. In addition, the agencies coordinated offers of assistance from the myriad of other voluntary civic groups, i.e., Parent and Teachers Associations, Chambers of Commerce; and so on. The agencies verified all sponsorship offers, and determines the potential sponsor's intentions and capacity to fulfill financial and moral obligations to the refugee family.

The resettlement agencies also operated offices at each of the re- 
fugee reception centers. They were staffed by a core of professional caseworkers assisted by volunteers. The caseworkers interviewed the refugee to determine family particulars -- size, composition, job skills, and geographic preferences. Then the agency matched the refugee family with an available sponsor. If both the refugee and the sponsor were agreeable to the proposed arrangement, the refugee was released from the camp. The resettlement agencies' responsibilities did not end at this point; they remained the backstop to assist the sponsor and refugee if the need arose. The Federal government granted the responsible resettlement agency $\$ 500$ for each refugee placed with a sponsor.

State and local governments also contracted to resettle refugees, albeit in numbers much smaller than the original 10 resettlement agencies. Governmental and private organizations who aided in resettlement included for example: (A) Department of Emergency Services, State of Washington; Governor's Task Force for Indochinese Resettlement, State of Iowa; Department of Institutions, Social Aid Rehabilitative Services, State of Oklahoma; Division of Community Services, State of Maine; Governor's Cabinet Secretariate, State of New Mexico Planning Office; Don Bosco Community Center; Indianapolis Area Chapter, American Red Cross; Chinese Consolidated Benevolent Association of Los Angeles; Chinese Consolidated Benevolent Association of New York. 39

\section{Sponsorship}

HEW felt that with few exceptions refugees required sponsors to assist in insuring that the refugee did not become dependent on public assistance. $^{40}$ Sponsors were to assist refugees in obtaining housing, employment and other assistance that would lead to self-sufficiency. 
These obligations were explained to sponsors. A statement to this effect was signed and contained the name and address of the sponsor. A local check was also done to determine as far as possible the sponsors' means to fulfill obligations. 41

\section{Travel}

Following the reception center clearance, the refugee could travel to the resettlement site using his own funds, his sponsor's, or the government's. In order to determine eligibility for government travel expenses, the assets of the refugee or sponsor were verified by HEW before travel was authorized. 42

\section{Medical Services}

Fort Chaffee. U.S. Army medical personnel provided ambulatory and inpatient medical care, dental care, and innoculations. On site medical resources consisted of three dispensaries, a dental clinic, and a 200-bed hospital with a staff of 47 officers and 153 enlisted men. The Public Health Service, Communicable Disease Center was responsible for surveillance of public health problems, control of communicable diseases, immunizations, and other preventive health measures. Health problems which exceeded the capabilities of the on site medical resources were referred to local community facilities or to specific public health service hospitals.

Indiantown Gap. The dispensary that was located in the camp met the needs of those who required medical attention and emergency treatment. Approximately 350 patients a day were treated there. Those who had a serious. illness and required hospitalization were transferred to the 
public health hospital in Baltimore, or to the Hershey Medical Center in Hershey.

Camp Pendleton. The main hospital at Camp Pendleton offered complete services in the following areas: general medicine, internal medicine, surgery, orthopedics, pediatrics, gynecology, obstetrics and dermatology. Services were also provided by clinics in the following areas: dental, dermatology, eye, ear, nose, and throat, electrocardiogram, inhalation therapy, and urology. A diagnostic lab also handled blood testing and biopsies.

Occupational and physical therapy were also available. A preventive medicine clinic dealing with follow-ups on tuberculosis, diabetes, and other diseases also existed. Heart surgery and neurosurgery could also have been performed at the hospital.

The psychiatric unit diagnosed refugees but treated only active U.S. military personnel. Refugees and their dependents were referred to San Francisco.

The majority of schoolage children were given required innoculations for DPT, first polio, mumps, typhoid, measles, and smallpox. ${ }^{43}$

\section{Food Service}

Fort Chaffee. At Fort Chaffee there existed three contracts for food service: food service, cook and dining facility, and refuse removal. Assuming 24,078 refugees, the following costs per refugee per day were calculated: food service per refugee -- \$1.59, cook and dining facility per refugee -- $\$ .66$, refuse removal per refugee -- $\$ .32$.

Indiantown Gap. There were 31 mess halls for the refugees. The refugees were fed an American diet, modified to suit Indochinese tastes, 
from a planned 15 day menu which changed every 16 th day. The mess halls were run under goverinent contract with Manpower, Inc.

Camp Pendleton. The camp food service was handled by South East Service Inc. An attempt was made to cater to Indochinese tastes in the preparation of weekly menus. Food items included large amounts of rice and fresh vegetables, chicken, pork, and fish. The daily cost was $\$ 1.70$ per refugee. 44

\section{Education and Training Programs}

Fort Chaffee. The educational and training programs were conducted by the Southern Baptist Convention and the Christian Reform World Relief Commission. The preponderance of classes was devoted to English language training, with classes presented for all ages. Cultural orientation programs such as home economics, shorthand, accounting, and construction engineering were available for persons who were interested. There was also an educational play program for the 3 to 6 and 6 to 10 year age groups.

Indiantown Gap. A regular school program was run by the Pennsylvania Department of Education. Prior to school enrollment, students were tested to determine education level. The school day consisted of five hours. The enrollment was approximately 2100, from ages 6 to 18 years. Curriculum included Englich, math, orientation to American schools, geography and United States history. Adult education courses were also given 2 to 3 hours per day; English language and American culture were offered.

Camp Pendleton. The goals of the Camp Pendleton program were designed to meet the needs of refugee adults and children by giving them a 
minimum educational experience, providing them with the English language skills and cultural orientation necessary for transition into American communities. The core program objectives consisted of survival language training geared to the needs of each particular age group, alon with general orientation to American culture and institutions. Extended objectives included:

1. For adults -- To insure that each participating adult would gain the basic facility in the English language needed to seek and obtain the basic requisites for living.

2. For children -- For participating high school age children, to insure a basic facility in English language, sufficient to function in American secondary schools. For participating elementary school age children, to insure that they would gain the basic facility in English language, including a "core" vocabulary so that they could more easily make the transition into American elementary schools. 45

\section{$\underline{\text { Recreational Activities }}$}

Fort Chaffee. The five refugee housing areas at Fort Chaffee were equipped to provide opportuniites for refugees to participate in a number of recreational activities. Indoor activities included table tennis, indoor basketbal1, weight lifting, boxing, gymnasium and television viewing. Outdoor sports equipment was available for soccer, basketball, badminton, and softball. A library was open daily for reading and for checking out books if it was so desired. There were also four motion picture theaters open each evening.

Indiantown Gap. In addition to sports familiar to the refugees (table tennis, volleyball, and soccer), American sports such as softball, 
were introduced. Scouting programs, art festivals, sing-alongs, theatricals, swimming events and dancing were also offered.

Camp Pendleton. Children's activities were provided by the American Red Cross. Play schools were organized into two hours, six days a week, for children 3 to 6 years old, with one play facility per camp area. The :American Red Cross provided exercise, recreation and educational programs to approximately 200 children per session, per camp area. Infant care items (diapers, infant sleepers, receiving and crib blankets) were provided and distributed to camps through the American Red Cross.

The YMCA coordinated all in-camp recreation activities. The YMCA also provided three activities which were targeted to the age group 18 and under: recreational activities (basketball, volleyball, soccer), entertainment and movies.

Varied children's activities provided at refugee request included: karate demonstrations, costume events, talent shows, dances, arts, and crafts classes and elementary school games.

The Salvation Army was the central. receiving point for all donations of children's clothes, toys, and books. Distribution was organized on an as needed basis to individuals through the camp structure and to organized children's activities. The Salvation Army also provided infants needs such as Iayettes and diapers.

The U.S. Marine Corps and the Navy supported the children's care and welfare effort. Services included providing a "warm trailer" for infants and invalids during the nights of extreme cold and staffing a prenatal and postnatal care center with Navy medical personnel.

Indochinese initiatives and leadership provided organized Boy Scout, Girl Scout and Girl Guide activities. Meetings were held twice weekly and 
Boy Scouts were credited for their activities through the international Boy Scouts association. 46

\section{Early Publications}

Early in the resettlement program HEW distributed the following publications: Information for Sponsors of Indochinese Refugees; The Indochinese Refugee Program: Questions and Answers; An Organization and Welcome Guide for Groups Sponsoring Indochinese Refugees; Cambodian/English, English/Cambodian Glossary; Vietnamese Refugee Orientation Handbook, United States Map; "Dear New Immigrant" Letter (explaining the legal assistance "hotline" and programs for Indochinese refugees; NEW LIFE (biweekly newspaper) printed in English, Vietnamese, and Cambodian and an. English/Vietnamese Dictionary. 47

Department of Health, Education and Welfare Programs for Refugees

Health. Health screening activities were provided by the Center for Disease Control (CDS) and patient care programs by the Bureau of Medical Services early in the resettlement program. "The Public Health Service (PHS) provided screening and immunization services to the refugee population. The health screening activities at the refugee camps were designed to identify and treat chronic and acute disease problems. Individuals were not released unless cleared by PHS-CDS screening. State health authorities were notified of diseases for necessary follow-up.

Indochinese refugees requiring long term medical or psychiatric inpatient or custodial care beyond that ordinarily provided in a general hospital were given such care at institutions other than reception centers and PHS facilities. If the patient was eligible under the Indochinese 
Refugee Program, payment for long term care was provided through the state medical assistance program having jurisdiction at the site of the receiving center. The state, in turn, would receive reimbursement from the federal government. 48

Dentist Program

Training. was made available to prepare refugee dentists for the National Board Dental Examination. The training was short term and implemented via contracts with selected dental schools. The refugee dentist was eligible for a round trip ticket from place of residence to the training location and could receive a stipend of $\$ 250$ per month during the training. There was no tuition cost to the refugee. By September, 1977, forty refugee dentists had received training at the programs' two locations.

\section{Physician Program}

A special program was also implemented for refugee physicians. The program provided educational assistance to physicians who had to pass the Educational Commission for Foreign Medical Graduates Examination. The examination is offered twice a year to foreign medical graduates as a prerequisite to their entry into an approved graduate training program, which is required for state licensure.

Approximately 484 refugee physicians received training under this Public Health Service program which was implemented at seven American medical centers. 49

\section{Medical Records}

The Public Health Service made a great effort to centralize the 
medical records of the refugees. The records were of importance not only for medical reasons but also to help the refugees secure jobs, enroll in school and to obtain insurance. 50

\section{Education}

Educational activities in the reception centers were as follows: during the latter part of June, 1975, HEW awarded contracts to California, Florida, and to West Arkansas Community College at Fort Smith, Arkansas for the development and operation of English classes and cultural orientation programs at each of the four reception centers.

At all four centers the refugees were screened and assigned to classes in beginning, intermediate or advanced English. Approximately one-half of the refugees were placed in beginning English, classes, onequarter in intermediate and another quarter in advanced classes. All of the camps had evening and Saturday acculturation classes. 51

Grants To State And Local Education Agencies

HEW developed policies to provide grants of $\$ 300$ to local educational agencies for each school age refugee child entering a school district. A school district enrolling more than 100 youngsters or onepercent of the total school district's enrollment received $\$ 600$ per child for ecah child above the 100 or one-percent threshold. The $\$ 300$ per child was considered the average cost of supplemental services for non-English speaking children. The figure of $\$ 600$ per child included $\$ 300$ for supplemental services plus an additional $\$ 300$ toward the cost of basic instructionin the heavily impacted districts which enrolled large amounts of refugee children. 
This policy also provided grants to state educational agencies for leadership and training purposes including services such as inservice training, curriculum identification and development, supervision, and technical assistance to districts with small numbers of refugee children. 52

\section{Bilingual Education Centers}

The Bilingual Education Centers provided technical assistance to school districts enrolling Indochinese refugees. Upon request, assistance with language and cultural curriculum development, and teacher training was provided. The Bilingual Resource Center was created to improve the capabilities of schools which had little or no experience serving Indochinese students; these services were provided through 1975, 1976 , and 1977.53

\section{Adult Education}

Funds were provided during 1975, 1976, and 1977 for refugee adult education. The funds required no additional matching on the part of states and local educational agencies and were provided to help states instruct adult Indochinese in speaking, understanding, reading, and writing Eng1ish.

Later in the resettlement program the adult education program was enlarged to include training in mathematics, promotion of literacy and the development of occupational skills. 54

\section{Georgetown "Hotline"}

Early in the program a "hotline" at Georgetown University was developed to respond directly to questions from refugees concerning post secondary education. The "hotline" functioned to supply post secondary 
educational information to refugees on a nationwide basis. The information supplied under this program included college admission procedures, and grants, loans, and scholarships which were available to Indochinese students. 55

\section{Center For Applied Linguistics}

An Indochinese refugee clearinghouse was established at the Center for Applied Linguistics. The purpose of the clearinghouse was to assist the nations' schools in dealing with English language problems of the refugees. The activities included: (1) materials development, (2) dissemination of information concerning materials available for teaching English to refugee children and adults, (3) a human resources bank of the names of available American specialists in teaching English as a second language, and (4) a translation selection service through which summaries of American text books in the language of the refugees or publication of Indochinese textbooks were made available. 56

\section{Post Secondary Education}

Refugees were made eligible for financial assistance for the purpose of entering and attending post secondary schools under the following programs: Basic Educational Opportunity Grant Program (BEOG), Supplemental Educational Opportunity Grant Program (SEOG), College Work-Study Program (CWS), National Direct Student Loan Program (NDSL), and Guaranteed Student Loan Program (GSLP). 57

\section{Credentials Evaluation Project}

The Credentials Evaluation Project began in December, 1975 to assure refugee students of equitable treatment and to assist admissions 
officers in post secondary intstitutions handling applications from. Indochinese refugee students.

As many of the students were unable to bring their academic records with them, the project undertook the review of students' educational history, the translation of documents or recreating of missing records, and a recommnedation concerning placement at the request of the institution considering the student's application.

The Office of Education also published two reports and distributed them to all colleges and universities in the nation. The reports were: Guidelines on the Admission and Placement of Refugees, and Guidelines on Admission and Placement of Refugees into U.S. Institutions of Higher Education. 58

\section{English Testing Project}

HEW Task Force contracted early in the resettlement program to administer an English language proficiency test to some 7000 refugees. This test is required of foreign students by most universities and colleges as evidence of English proficiency for admissions and placement purposes. 59

\section{Supportive Services}

Family Locator Service. HEW contracted with the Red Cross to share the costs of the Family Locator Service for Indochinese refugees. The Red Cross performed the function as part of its normal program but because of the increased volume created by the Indochinese, the federal government agreed to chare the costs of the effort. 60

Young Lawyers Section/American Bar Association. HEW contracted with the Young Lawyers Section of the American Bar Association to provide legal assistance to refugees via a toll free telephone. Later in the resettle- 
ment program, HEW contracted with that group to do research on legal issues concerning the. Indochinese refugees. Subsequent research papers dealt with extending the constitution to refugees parolees; adoption of Vietnamese children; the dilemma of the consent requirement; constitutional problems confronting the Vietnamese refugees; the legal status of the Indochinese refugees; and legal aspects of the sponsor relationship. 61

California Demonstration Project. In late 1976, HEW funded four training-employment projects in California - the cost was $\$ 2$ million. The projects were designed for those refugees receiving cash assistance or in imminent need of it. A portion of the participants were expected to find jobs or be upgraded in their present jobs, another portion were expected to enter advanced training programs such as on-the-job situations with paid stipends. As the termination of this program, it had grown to 62 projects costing $\$ 7$ million designed to accomplish the above plus English language, voactional training, and job development. 62

Activities of the Office of Special Concerns. The Office of Special Concerns was created early in the program for the purpose of developing feedback from the refugees both in refugee centers and after resettlement. The office of Special Concerns director reported directly to the director of the Interagency Task Force, and was an executive associate of the Task Force organization. There were two divisions: the in-camp division was composed of U.S. personnel, all of whom were Vietnamese linguists and detailed from the Department of State and the Agency for International Development; the post-camp division was composed of professional specialists detailed from domestic agencies such as HEW. Trained Vietnamese 
and Cambodian evaluators worked on in-camp and post-camp matters and were also available to other Interagency Task Force components and cooperating agencies. 63

\section{Repatriate Program}

U.S. Repatriates. The Temporary Assistance for Repatriates Program provided money to U.S. citizens or the dependents of a U.S. citizen who were forced to leave Indochina under emergency conditions, who had been returned to the United States and who were not eligible for other income maintenance programs.

Financial assistance included money for food, shelter, clothing, medical care, and transportation. It also included payments for special services such as foster home care for children. Also provided were guidance, counseling, and if necessary, vocational rehabilitation services. Indochinese Repatriates. The refugees who wished to return home were processed under a voluntary removal program directed by the Department of State and the Immigration and Naturalization Service. United Nations High Commissioner liaison officers were posted in the camps to establish and supervise procedures to be followed by refugees who wished to repatriate. 64

\section{Financial and Medical Assistance}

During the first three months of resettlement, HEW revised policies on financial and medical assistance to resettled refugees. They were as follows: the refugee was eligible for medical assistance immediatel after resettlement and this did not depend on or imply a breakdown in the sponsorship of the refugee. Under the policy, the sponsor was expected 
to continue to fulfill the moral commitment to meet routine or ordinary medical costs but the refugee medical assistance program was available to meet major medical needs if they arose.

The eligibility of a needy refugee for financial assistance did not depend on a breakdown in the sponsor-refugee relationship, this was to continue even if a sponsor became unable to continue to provide for the material needs of the refugee. As in the regular welfare programs, the refugees' eligibility for financial assistance was based on the refugees' needs in terms of the income and resources actually available to the refugee.

The state public welfare agency was not required to obtain a written statement from a sponsor when a refugee applied for financial or medical assistance. The requirement continued, though, that the state agency was to verify with the sponsor as to what assistance the sponsor was providing. A verbal statement by the sponsor to the state agency was sufficient, as the sponsor had not assumed legal responsibility for the refugee. For social services, medical assistance, and income maintenance, states were reimbursed for all costs incurred. 65

\section{Unaccompanied Children}

Children who reached the United States unaccompanied by responsible adults were the object of individual plans to assure protection, rights, care and the resolution of custody rights. To this end, arrangements were made with state or $10 \mathrm{cal}$ public child welfare agencies in the states in which the camps were located to establish offices and provide professional staff on site at the camps. As most of the children were not initially available for adoption, foster placement was deemed the most appro- 
priate plan for providing care, since this would permit their being re-: united with their families. A master list of unaccompanied children was developed and states were asked to confirm the arrangement of follow-up visits to assist children and families with any problems that might develop. 66

\section{U.S. Department of Labor}

The U.S. Department of Labor provided on site assistance at the reception centers, through its affiliated state employment services. An assessment of refugee occupational skills was done and labor market information was provided to the volunteer agencies for their consideration in determining areas in which to resettle refugees.

Placement assistance was available free of charge to any resettled refugee through local public employment service offices operated by the State Employment Service Agencies.

Under the Comprehensive Employment and Training Act (CETA), 1oca1 "prime sponsors" codild have enrolled refugees in their manpower programs.

Prior to their departure from the reception center, refugees were provided with information as to how to locate their State Employment Service Agency, when they reached their sponsor's location. It was thought that a refugee could receive service in the area of resettlement where the most specific information was available and where job interviews could be conducted by potential employers. Reports of activities of the State Employment Service Agencies from across the country, relating to refugee activities, were telephoned to the Department of Labor in Washington D.C. bi-monthly. The information was provided to the Secretary of Labor and to the Interagency Task Force. 
Employment service personnel from the Labor Department were stationed at each of the resettlement centers to provide technical assistance in determining occupational skills of the refugees. Staff members were also available to the voluntary agencies for interpretation of labor market information occupational outlook data, and upon request, evaluation of sponsors' offers of employment. ${ }^{67}$

\section{Department of Agriculture/Food Stamps}

Indochinese refugees became eligible for participation in the food stamp program on the same basis as all other applicants with the exception of citizenship or permanent resident alien status requirements, which were waived for refugees. The refugee household had to meet all other financial or nonfinancial eligibility criteria. ${ }^{68}$

Department of Housing and Urban Development

The Department of Housing and Urban Development (HUD) had several housing programs available to refugees. The sources of subsidized housing were: low rent public housing; section 236 multi-family rental housing, rent supplement programs; and the section 8 housing assistance program. Also, homes held by HUD were regularly offered for sale and refugees were eligible to purchase them. ${ }^{69}$

\section{Baby Lift Children}

These were the children who were flown from orphanages in Vietnam through private agencies prior to the mass evacuation. The children in this group were processed to determine their eligibility for adoption. If they were found eligible for adoption -- proceedings took place. The problem that was most substantial was attempting to make contact with the 
parents in Vietnam. 70

\section{Smal1 Business Adminsitration}

Personnel from the Small Business Administration (SBA), including a refugee consultant, conducted general sessions plus seminars in each of the reception centers. Also a small business investment corporation was funded with $\$ 500,000$ from the SBA plus $\$ 500,000$ invested by refugees. This corporation made business loans to refugees to enable them to start sma11 businesses. 71

\section{Legal Service Corporation}

Refugees, if under maximum income guidelines established by the Legal Service Corporation were eligible for a full range of legal assistance, i.e., advice, coursel, representation, litigation and appeal on non-criminal matters. 72

\section{Mental Health Projects}

Five projects were funded to deal with refugee mental health problems -- primarily depression. The projects utilized Indochinese bilingual paraprofessionals, psychiatrists, physicians and clinical social workers. Because of language, and cultural problems, Western modes of psychiatric treatment were nearly useless. The projects thus sought to create novel approaches to mental health problems. 73

At this interval, it should be evident to the reader that the Indochinese refugees were not left to their own means subsequent to their evacuation from Indochina and arrival in the United States. Virtually every refugee was affected by the efforts of the Federal govermment to, through social services, facilitate resettlement. These services were 
extensive as well as expensive, and were initiated to aid the refugees in resettlement. But what are the refugees' perceptions of the services? Our study is concerned with this question, as we feel the refugees attitude toward and perception of these services should be taken into account by those planning and delivering services to the Indochinese in America. 
NOTES

${ }^{1}$ John Simsopson, "The Refugee Problem," Annals of the American Academy of Political and Social Science, May 1939, p. 45.

${ }^{2}$ U.S. Cong., A Study Mission Report prepared for the Committee on the Judiciary, 95th Cong., 1st sess., December 1977, p. 56.

3 Simsopson, p. 13.

${ }^{4}$ Louise W. Holborn, Refugee: A Problem of Our Time (United Nations High Commissioner for Refugees, 1951-72), pp. 795-800.

${ }^{5}$ Holborn, pp. 795-800.

6 Robert Shaplen, "A Reporter at Large," The New Yorker, September 1977 , p. 33.

7 Shaplen, p. 33 .

${ }^{8}$ Galen Beery, "Special Report, Indochina Refugees: Resettlement Progress," The Christian Century, October 1976, p. 931.

9 The term "boat cases" refers to those refugees, largely Vietnamese and Cambodian who escaped their homelands by sea since the beginning of 1976. They make up the latest group in the Indochinese refugee rescue program. The United Nations High Commissioner for Refugees indicated that boat cases are among the most unusual and dramatic experiences. Many refugees attempted to flee their homelands in old, unseaworthy boats. Many perished out in the open sea.

10 Milton M. Gordon, Assimilation in American Life (New York: Oxford University Press, 1964), p. 11.

${ }^{11}$ Eleanor M. Rogg, The Assimilation of Cuban Exiles: The Role of Community and Class (New York: Aberdeen Press, 1974), p. 3.

${ }^{12}$ S. N. Eisenstadt, The Absorption of Immigrants (New York: Free Press, 1955), p. 4 .

${ }^{13}$ Gordon, p. 242.

14 Jerold Eeiss, "Factors Related to Immigrant Assinilation: Premigration Traits," Human Organization, 26, 1967, p. 265. 
15 James W. Vander Zanden, American Minority Relations (New York: Ronald Press, 1963), pp. 277-280.

${ }^{16}$ Gordon, p. 52 .

17 Robin Williams, American Society: A Sociological Interpretation (New York: Knopf, 1951), p. 48.

${ }^{18}$ Melford E. Spiro, "The Acculturation of American Ethnic Groups," American Anthropologist, 57, 1955, p. 1243.

${ }^{19}$ Rogg, p. 17.

${ }^{20}$ Rogg, p. 18.

21 Joseph B. Sechectman, The Refugee in the World: Displacement and Integration (New York: A. S. Barnes, 1963), p. 25.

22 H.B.M. Murphy, Flight and Resettlement (Lucerne: C.J. Bucher, Ltd., 1955), p. 91.

23 Murphy, p. 91.

24 Raymond Breton and Maurice Pinard, "Group Formation Among Immigrants: Criteria and Processes," Canadian Journal of Economics and Political Science, 26, 1960, p. 465 .

${ }^{25}$ S. Alexander Weinstock, "Role Elements: A Link Between Acculturation and Occupational Status," British Journal of Sociology, 14, 1963 , p. 144.

${ }^{26}$ Henry P. David, "Involuntary International Migration: Adaptation of Refugees," International Migration, 7, 1969, p. 34.

27. Eitinger, "The Incidence of Mental Disease Among Refugees in Norway," Journal of Mental Science, 105, 1959, p. 326.

${ }^{28}$ Murray P. Naditch and Richard Morrissey, "Role, stress, personality and psychopathology in a group of immigrant adolescents," Journal of Abnormal Psychology, 85, 1976, p. 43.

${ }^{29}$ Keh-Ming Iin, Laurie Tazuma, and Minoru Masuda, "Adaptational Problems of Vietnamese Refugees, Part I: Health and Mental Health Status," Unpublished report, University of Washington, 1977.

${ }^{30}$ Study Mission Report, p. 70.

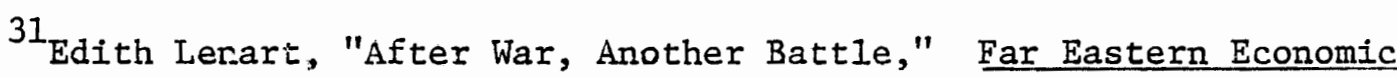
Review, April 29, 1977, p. 22.

32 The Report of the Uncle Counselor, Southeast Asian Mental Health Project, (Los Angeles: October 1976 - July 1977). 
33 Report of the Uncle Counselor.

${ }^{34}$ Study Mission Report, p. 71.

35 HEW Task Force For Indochinese Refugees, Report to the Congress Sept. 21, 1977 (Washington D.C.: Dept. of HEW), p. 31.

${ }^{36}$ HEW Report to Congress, Sept. 21, 1977, p. 100.

37 HEW Report to Congress, Sept. 21,1977, p. 41.

${ }^{38}$ HEW Task Force For Indochinese Refugees, Report to the Congress

Sept. 15, 1975 (Washington D.C.: Dept. of HEW), p. 17.

39 HEW Report to Congress, Sept. 15,1975, p. 35.

40 HEW Report to Congress, Sept. 15, 1975, p. 33.

${ }^{41}$ HEW Report to Congress, Sept. 15, 1975, p. 34 .

42 HEW Report to Congress, Sept. 15, 1975, p. 20.

43 HEW Report to Congress, Sept. 15, 1975, p. 22.

${ }^{44}$ HEW Report to Congress, Sept. 15, 1975, p. 24.

45 HEW Report to Congress, Sept. 15, 1975, p. 27.

46 HEW Report to Congress, Sept. 15, 1975, p. 30.

47 HEW Report to Congress, Sept. 15, 1975, p. 31.

${ }^{48}$ HEW Report to Congress, Sept. 15, 1975, p. 58.

${ }^{49}$ HEW Report to Congress, Sept. 15, 1975, p. 74.

50 HEW Report to Congress, Sept. 15, 1975, p. 60.

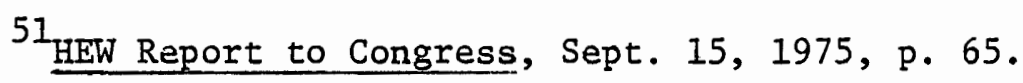

52 HEW Report to Congress, Sept. 15, 1975, p. 66.

53 HEW Report to Congress, Sept. 15, 1975, p. 67.

${ }^{54}$ HEW Report to Congress, Sept. 15, 1975, p. 67.

55 HEW Report to Congress, Sept. 15, 1975, p. 67.

${ }^{56}$ HEW Report to Congress, Sept. 15,1975, p. 68.

57 HEW Report to Congress, Sept. 15, 1975, p. 69. 
58 HEW Task Force For Indochina Refugees, Report to the Congress June 20, 1977 (Washington D.C.: Dept. of HEW), p. 56.

${ }^{59}$ HEW Report to Congress, June 20,1977, p. 56.

$60_{\text {HEW Task Force For Indochina Refugees, Report to the Congress }}$ June 15, 1976 (Washington D.C.: Dept. of HEW), p. 41.

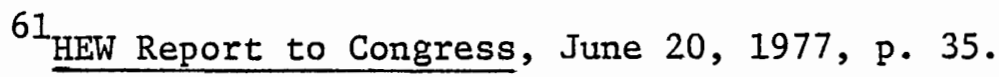

62 HEW Report to Congress, June 20,1977, p. 35.

${ }^{63}$ HEW Task Force For Indochina Refugees, Report to the Congress December 15, 1975 (Washington D.C.: Dept. of HEW), p. 46.

${ }^{64}$ HEW Report to Congress, Sept. 15, 1975, p. 50.

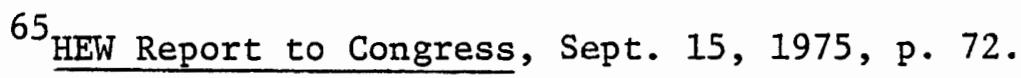

66 HEW Report to Congress, Sept. 15, 1975, p. 74.

67 HEW Report to Congress, Sept. 15, 1975, p. 87.

${ }^{68}$ HEW Report to Congress, Sept. 15, 1975, p. 93.

${ }^{69}$ HEW Report to Congress, Sept. 15, 1975, p. 94.

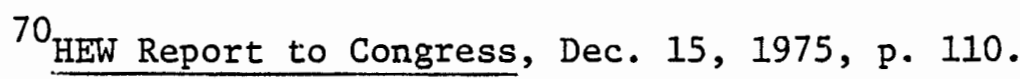

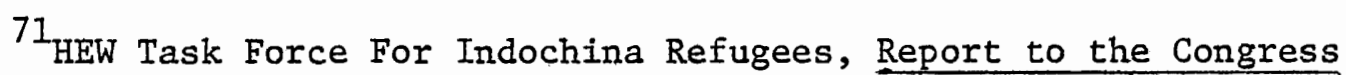
March 15, 1976 (Washington D.C.: Dept. of HEW), p. 122.

72 HEW Report of Congress, June 15, 1977, p. 129.

73 HEW Report to Congress, Sept. 21,1977, p. 46. 
This study was conducted in two phases. As one of the purposes of the research was to distinguish between successful and unsuccessful adaptation of Indochinese refugees, criteria for defining successful and unsuccessful were necessary. This became the focus of the preliminary phase of the study. The major phase of the research concentrated on those areas identified as primary considerations of the study: refugee demographic data; indicators of successful refugee resettlement; and refugee attitudes and perceptions about social services programs and barriers to resettlement.

\section{POPULATION}

The Vietnamese, Cambodian, and Laotian refugee populations of the Portland metropolitan area served as subject populations for the study. It was estimated from information provided by the Indochinese Refugee Program, Department of Health, Education, and Welfare, Salem, Oregon, that there were approximately 2500refugees (1650 Vietnamese, 480 Cambodians, and 265 Laotians) residing in the Portland metropolitan area as of November, 1977.

\section{SAMPLING INIORMATION}

\section{Preliminary Phase}


The sampling frame for the preliminary phase consisted of Vietnamese, Cambodian, and Laotian refugees enrolled in English-as-a-SecondLanguage (ESL) classes at Portland Community College -- Ross Island Center and Cascade Center; Portland State University; and the Indochinese Cultural Center in Portland.

A total of 100 refugees from all three groups was set as a manageable sample population for the preliminary phase. The number of refugees in each group sample was derived by caluculating the proportion of each group within its respective general Portland-area Indochinese population. As the Vietnamese population represented well over $70 \%$ of the total Indochinese population, adjustments were made in order to accomodate more representation of the less populous Cambodian and Laotian groups. Group sample sizes of 54 Vietnamese, 30 Cambodians, and 16 Laotians made up the total sample population of 100 refugees.

\section{Major Phase}

The sampling frame for the major phase consisted of the mailing lists for the pulbications, "Vietnamese News," "Cambodian News," and "Laotian News," distributed by the Indochinese Cultural Center in Portland, Oregon. This Iist included 500 Vietnamese, 97 Cambodians, and 55 Laotians, who were designated heads of households.

A manageable total sample population was set at 300 refugees. The number of refugees in each group sample was derived by calculating the proportion of each head of household group within its respective general Portland Indochinese population. The Vietnamese population with over $70 \%$ in the general Indochinese population was represented in the major phase by 235 refugees. The Cambodian population with $20 \%$ representation in the 
general Indochinese population was represented in the major phase by 50 refugees. The Laotian population with $10 \%$ representation in the general Indochinese population was represented by 25 refugees.

Sample respondents were chosen from the sampling frame according to a table of random numbers.

\section{DATA COLLECTION METHODS}

For both the preliminary and major phases of the study, the questionnaire was chosen as a basic means of data collection. It was felt that a questionnaire would provide the anonymity necessary to provide honest responses. This has been indicated by previous researchers of Indochinese populations to be an important issue. ${ }^{1}$ Indochinese have been hesitant to discuss their lives in the United States as they fear that the information will be used against them; or that they might sound ungrateful to their American hosts. A questionnaire would provide the Indochinese with an opportunity to express themselves without fear of embarrassment or recrimination. Also, by expressing their thoughts in written form, they would have time to think over their responses, time that is perhaps especially needed when questions are asked that might be difficult to answer. A questionnaire could also provide a greater degree of standardization of response, making the data more manageable, while, at the same time, providing the respondents with an opportunity to comment in more detail about their thoughts and reeds.

Interviewing the Indochinese in their homes as a method of data collection was also considered. The major phase provided the opportunity to interview refugees. An additional sample of 30 refugees ( 10 
from each group) was drawn from the sampling frame.

$$
\text { DEVELOPMENT OF THE QUESTIONNAIRES }
$$

\section{Preliminary Phase}

Since the major focus of the questionnaire, in this phase, was to define criteria for successful and unsuccessful resettlement, Maslow's hierarchy of needs was consulted in order to develop resettlement goal categories. Maslow's categories of man's needs ranged from basic needs of physiology to higher needs or metaneeds of personality development. ${ }^{2}$ Fourteen goal categories, corresponding the Maslow's categories, were considered: housing, transportation, employment, education, familyfriends, culture maintenance, finances, insurance, legal services, family planning, medical-health, recreation-leisure, food, and residency status. Thirty-six items reflective of these categories were formulated for the questionnaire. Respondents were asked to rank each item according to their view of its importance in successful resettlement.

An additional source of data -- 17 barrier conditions to successful resettlement -- was also presented in the preliminary phase questionnaire. Respondents were asked to indicate those conditions which prevented them from becoming successfully resettled.

A copy of the preliminary phase questionnaire can be found in Appen$\operatorname{dix} A$.

\section{Major Phase}

Using the data collected in the preliminary phase, 15 items which were ranked consistently (over $50 \%$ of the time) "most important" were included in the major phase questionnaire as indicators of successful 
refugee resettlement. Questions reflective of demographic data were presented as well as questions reflective of the refugees' perceptions and attitudes toward social service resources. Consultation with recognized leaders of each Indochinese group was conducted in the formulation of these questions.

A copy of the major phase questionnaire can be found in Appendix A. SOME VARIABLES AND POSSIBLE INFLUENCES TO RESETTLEMENT

\section{Demographic Variables}

Age. The age of a refugee may have some bearing on his or her resettlement. Younger refugees tend to have an easier time in adapting to a new culutre. The group of successful refugees, therefore, is expected to be largely composed of younger persons.

Sex. Asian cultures tend to be male-dominated. The majority of heads of households are expected to be male.

Marital status. The family unit is an important aspect of Indochinese cultures. Having a spouse and a family can provide much emotional support. For refugees attempting to assimilate into a new culture, this support would seem to be most beneficial to resettlement. Thus, a refugee having a spouse and/or a family with him/her in the new country would probably be more successfully resettled than a refugee not having a spouse and/or family with him/her.

Occupation. Education and occupation are very highly correlated variables. Higher education can mean higher status occupations. Higher status occupations can lead to greater social mobility and more successful resettlement for refugees. Those refugees with higher status occupa- 
tions in their homelands would be expected to be more successfully resettled than those refugees with lower status occupations in their homelands. English language ability. Successful refugees tend to be those who are able to communicate in the language of their new country. Successful refugees, then, will be expected to have greater proficiency in speaking and reading English.

Length of stay in America. The longer the length of stay in a new country, the greater the chance for successful resettlement. The successful group of refugees will be expected to have spent a longer period of time in the United States than the unsuccessful group.

Religion. It could be expected that those who identify with a religion would be better able to adjust to a new culture, as they would be likely to receive emotional and social support from the religion and from the community of worshippers.

\section{Attitudinal Variables}

Hope to return to homeland. If the situation of being in America is seen as temporary, steps will not be taken to try to adjust to the American culture. If the respondent sees his return to his homeland as being a reality in the near future, he will perceive even more so the present situation as being temporary. A respondent who perceives his stay in America as being somewhat permanent would take the-necessary measures to help himself adjust to American life.

Awareness of social service resources. Being aware of the various social service resources in the Portland area can greatly facilitate resettlement in the area. Successful refugees, then, will be expected to have more experiences and contacts with social service agencies, and know- 
ledge of where to get help for problems.

\section{QUESTIONNAIRE TRANSLATIONS}

Translating of the questionnaires for both the preliminary phase and the major phase was carried out by interpreters at the Indochinese Cultural Center in Portland. For each questionnaire, several interpreters for each language (Vietnamese, Cambodian, and Laotian) were utilized in order to work out any problems that might have occurred in the translations. Copies of each questionnaire can be found in Appendix A. DISTRIBUTION OF THE QUESTIONNAIRES AND RESPONSE RATES

\section{Preliminary Phase}

A total of 100 questionnaires (54 Vietnamese, 30 Cambodian, and 16 Laotian) were distributed in ESL classes at Portland Community College, Portland State University, and the Indochinese Cultural Center in Portland. The respondents were asked to complete the questionnaires in class, in the presence of a researcher who provided interpretation when necessary.

A total of 90 questionnaires (46 Vietnamese, 28 Cambodian, and 16 Laotian) were collected for analysis. Approximately 8 Vietnamese and 2 Cambodian questionnaires could not be collected.

\section{Major Phase}

A total of 300 questionnaires (235 Vietnamese, 50 Camobodian, and 26 Laotian) were distributed through the mail. Each questionnaire included a stamped, addressed envelope in which the respondent could return the complete questionnaire.

A total of 53 questionnaires (42 Vietnamese, 11 Cambodian, and 8 
Laotian) were returned undeliverable.

The questionnaires collected for analysis included 51 Vietnamese, 10 Cambodian, and 17 Laotian -- a total of 78 questionnaires. These small numbers of responses made for a rather weak data base.

Plans to interview an additional sample of nonrespondents in their homes were abandoned after numerous attempts to contact willing respondents proved futile. Initial contacts with sample respondents were made through an interpreter via telephone calls. Those contacted, for the most part, did not wish to be interviewed. Reasons most often cited included time conflicts and disinterest in the subject matter.

\section{DATA TABULATION AND ANALYSIS}

The items in both questionnsires were put on punch cards. Computer programs were prepared to tabulate the findings and convert the tabulations into percentage statistics.

An analysis of variance (one-way design) was performed on variables of the major phase questionnaire.

Ideally in a study of this nature, every individual in the universe (all Indochinese refugees in Portland) would be contacted to obtain precise answers. Cost and time restraints dictated the use of a sample of Indochinese refugees to conduct the study. The sampling frames for both questionnaires consisted of recognized Indochinese population bases -ESL classes and heads of households. These two decisions prevented the non-ESL refugees and the non-head of household adult refugees, females, for the most part, from being included in the study. In analyzing the results of the study, these factors must be considered. 
Other factors which the researchers felt should be taken into consideration when analyzing the results, the major phase findings, in particular, include: the refugees' basic unfamiliarity with surveys and questionnaires, the rate of returned undeliverable questionnaires (approximately $18 \%$ ), and the possibility that questions on the major phase questionnaire may have been misunderstood by some refugees. 
NOTES

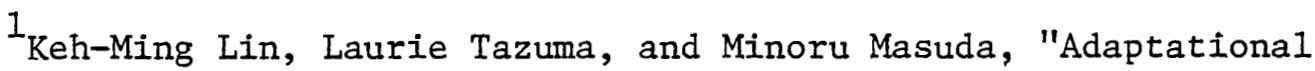
Problems of Vietnamese Refugees, Psrt I: Health and Mental Health. Status," Unpublished report, University of Washington, 1977; and Jean Immel, Vietnamese and Cambodian Study, Unpublished report, Portland State University, 1977.

2 Richard Holme, ed., Abnormal Psychology: Current Perspectives (Del Mar, California) Communications Research Machines, Inc., 1972). 
CHAPTER IV

FINDINGS

\section{PRELIMINARY PHASE}

The aim of the preliminary survey was to gain definitions of the successfully and the unsuccessfully resettled refugee, and to gain insight into the refugee's perceptions of possible barriers to realizing successful resettlement. The tables that follow illustrate the findings of the preliminary phase survey.

In the preliminary phase survey, the refugees, through their responses to 28 items, defined "successful" and "unsuccessful" as it relates to resettlement. The items presented were stated as goals, and these goals ranged from the acquistion of material objects to the opportunity to exercise religious activities.

Table I depicts those items or goals which $50 \%$ or more of the total average of the refugees considered "most important" to successful resettlement.

Table II depicts those items or goals which $20 \%$ or more of the total average of the refugees considered "least important" to successful resetlement. 
TABLE I

ITEMS/GOALS CONSIDERED MOST IMPORTANT TO SUCCESSFUL RESETTLEMENT BY 50\% OF THE TOTAL AVERAGE OF INDOCHINESE REFUGEES

Item/Goa1

\section{$\frac{\text { Vietnamese }}{\mathrm{N}=46}$}

$56 \%$

59

47

20

16

53

55

22

40

47

27

41

45

50

44

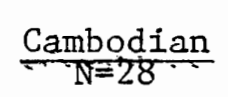

$84 \%$

90

67

79

72

39

83

87

69

74

61

67

79

61

72 $\frac{\text { Laotian }}{\mathrm{N}=16}$

$93 \%$

88

81

69

73

67

71

56

56

87

81

80

88

67

67

TABLE II

ITEMS/GOALS CONSDIERED LEAST IMPORTANT TO SUCCESSFUL RESETTLEMENT BY 20\% OF THE TOTAL AVERAGE OF INDOCHINESE REFUGEES

Item/Goal

1. Rent a home or apartment

2. Live in a rural area

3. Ability to ride a bus

4. Job equal to former job in Asia

5. Having no job and on welfare

6. Graduating from U.S. 4-yr. college 38

7. Living alone in home or apt. 62

8. Belong to cultural organization 34

9. Having credit for loans, etc. 25

10. Ability to acquire attorney 41

11. Having a large family

12. Being accustomed to U.S, foods

45

31

$\frac{\text { Vietnamese }}{\mathrm{N}=46}$

$14 \%$

65

55

28

35

62
Cambodian $\mathrm{N}=28$

$\frac{\text { Laotian }}{N=16}$

$18 \%$

6

11

29

24

19

38

18

11

6

22

17
$43 \%$ 
If the reader recalls, "barrier conditions" are those elements in the refugees' profile or environment that might hinder or prevent him from realizing "successful resettlement" status. What follows is a tabIe indicating what percentage of the sample felt a particular "barrier condition" was a significant hinderance. Table II indicates, respectively', the Vietnamese, Cambodian, and Laotian responses.

\section{TABLE III}

PERCENTAGE DISTRIBUTION OF INDOCHTNESE RESPONSES TO

BARRIER CONDITIONS TO SUCCESSFUL RESETTLEMENT

\section{Barrier Condition}

1. Not knowing enough English

2. Not haying a good job

3. Racial discrimination

4. Not having enough job training

5. Job discrimination

6. Lack or recertification

7. Finding jobs to be scarce

8. Cultural misunderstanding on job

9. Lack of financial aid for school

10. Inadequate housing

11. Family members not in U.S.

12. Unorganized cultural orgs.

13. Discrimination in loans $\&$ credit 11

14. Different religious \& cultural ideas

15. Nonarailability of certain cultural items (food, clothing) 11

16. Not having permanent resident status

17. Desire to return home someday

\section{Vietnamese $\mathrm{N}=46$.}

$49 \%$

32

24

26

15

26

30

37

\section{7}

24

24 $\frac{\text { Cambodian }}{N=16} \quad \frac{\text { Laotian }}{N=28}$

$81 \%$

$29 \%$

$88 \quad \cdot 21$

$63 \quad 14$

$50 . \quad 11$

$88 \quad 11$

$81 \quad 25$

$81 \quad 25$

$63 \quad 25$

$63 \quad 14$

$63 \quad 18$

$75: \quad 18$

$63 \quad 11$

$44 \quad 21$

$63 \quad 7$

$22 \quad 50 \quad 11$

$11 \quad 63 \quad 32$

The Vietnamese group indicated that "not knowing enough English" hindered resettlement the greatest, while "discrimination in loans and credit," "nonavailability of certain cultural items," and "desire to return home scmeday," least hindered resettlement. The Laotian group 
indicated "desire to return home someday," as greatest hindrance to resettlement, while "nonavailability of certain cultural itmes," was least hindering. The Cambodian group felt, as did the Vietnamese, that "not knowing enough English;" most significantly hindered resettlement, while having "different religious and cultural ideas," least hindered resettlement.

\section{MAJOR PHASE}

The major phase questionnaire, when developed, was divided into three sections. Section I was concerned with the demographic characteristics of the respondents. Section II focused on questions reflective of the current lifestyles of the refugees, which, for the most part, served as indicators of the refugees' successful or unsuccessful resettlement status. Section III asked refugees to respond to items reflecting their awareness and perceptions of American social services.

\section{Demographic Characteristics of the Respondents}

Age. None of the respondents were over 60 years of age, or under 20 years of age. The greatest number of Vietnamese and Cambodian respondents were in their thirties, while the Laotians were in their late twenties. Between successful and unsuccessful groups, no distinct differences were indicated. Table IV depicts this information.

Sex of the Respondents. As anticipated, an overwhleming majority of the respondents were male. The few female respondents in each group comprised less than $20 \%$ of the group total. Table $\mathrm{V}$ depicts this information. 
TABLE IV

DISTRIBUTION BY AGES OF SUCCESSFUL AND UNSUCCESSFUL REFUGEES

Age Category

Under 20 years

21 - 30 years

31 - 40 years

41 - 50 years

51 - 60 years

Over 60 years

No Response

$$
\frac{\text { Viet }}{N=28} \quad \frac{\text { Successful }}{N=5} \quad \frac{\text { Lao }}{N=10} \quad \frac{\text { Viet }}{N=23} \quad \frac{\text { Unsuccessful }}{N=5} \quad \frac{\text { Cam }}{N=7}
$$

$\begin{array}{cccccc}6(1 \overline{7} .9 \%) & 1(20 \%) & 3(30 \%) & 9(3 \overline{9} .2 \%) & 1(20 \%) & 2(28.6 \%) \\ 15(53.6) & 1(20) & 7(70) & 8(34.8) & 2(40) & 5(71.4) \\ 4(15.7) & 2(40) & - & 5(21.7) & 1(20) & - \\ 3(12.8) & 1(20) & - & 1(4.3) & 1(20) & - \\ - & - & - & - & - & - \\ - & - & - & - & - & -\end{array}$

$\underline{\text { Sex }}$

Cambodian Laotian

Male

Female

No Responses

\section{TABLE V \\ DISTRIBUTION OF RESPONDENTS' SEX \\ BY ETHNIC GROUP \\ BY ETHIC GROUP}

Vietnamese
$\begin{gathered}40(78 \%) \\ 9(18) \\ 2(4) \\ \mathrm{N}=51\end{gathered}$

$\mathrm{N}=51$

$$
7(70 \%)
$$$$
2(20)
$$$$
1(10)
$$

$\mathrm{N}=10$
$15(88 \%)$

$2(12)$

$\mathrm{N}=17$

Marital Status. A clear majority of the respondents were married, with a majority of spouses being present in the United States. Between successful and unsuccessful groups, no clear differences existed. Table VI illustrates this information. 


\section{TABLE VI}

DISTRIBUTION OF MARITAL STATUS AMONG SUCCESSFUL AND UNSUCCESSFUL REFUGEES

Marital Status

Single

Married

Spouse in U.S.

Divorced

Separated

Widowed

No Response
Successful

$\frac{\text { Viet }}{N=28} \quad \frac{\mathrm{Cam}}{\mathrm{N}=5} \quad \frac{\mathrm{Lao}}{\mathrm{N}=10}$
Unsuccessful

$\frac{\text { Viet }}{N=23} \quad \frac{\text { Cam }}{N=5} \quad \frac{\text { Lao }}{N=7}$

$\begin{array}{cccccc}8(28.6 \%) & 2(40 \%) & - & 8(40 \%) & 2(40 \%) & - \\ 19(67.9) & 3(60) & 10(100 \%) & 12(59.9) & 2(40) & 7(100 \%) \\ 16(84) & 2(67) & 10(100) & 6(50) & 2(100) & 7(100) \\ - & - & - & - & 1(20) & - \\ - & - & - & 1(5) & - & - \\ - & - & - & 2(10) & - & - \\ 1(3.5) & - & - & - & - & -\end{array}$

Former Occupations. Military occupations and students made up the majority of former occupations. Between the successful and unsuccessful groups, some differences were indicated. The successful group accounted for more professional, white-collar type occupations. The unsuccessful group accounted for more military-related, labor occupations. The students seemed to be evenly dispersed between the groups.

\section{TABLE VII}

RANGE OF FORMER OCCUPATIONS AMONG SUCCESSFUI AND UNSUCCESSFUL REFUGEES

Occupation

Military

Students

Business

Gov't. Employee

Labor

Education

Medical

Other Professional

Domestic

No Response $\underline{\text { Successful }}$

$$
\frac{\text { Viet }}{\mathrm{N}=28} \quad \frac{\mathrm{Cam}}{\mathrm{N}=5} \quad \frac{\text { Lao }}{\mathrm{N}=10} \quad \frac{\text { Viet }}{\mathrm{N}=23} \quad \frac{\text { Cam }}{\mathrm{N}=5} \quad \frac{\text { Lao }}{\mathrm{N}=7}
$$

$\begin{array}{llllll}5(17.9 \%) & 1(20 \%) & 3(30 \%) & 6(30.6 \%) & 2(40 \%) & 5(71.4 \%) \\ 6(21.4) & 1(20) & 2(20) & 4(17.4) & 1(20) & 1(14.3) \\ 2(7.1) & 1(20) & 1(10) & 3(13) & - & 1(14.3) \\ 5(17.9) & 1(20) & - & - & - & -\end{array}$

$\begin{array}{llllll}5(17.9) & 1(20) & - & - & - & -\end{array}$

$\begin{array}{cccccc}- & - & 1(10) & 1(4.3) & 1(20) & - \\ 3(10.8) & - & 1(10) & 5(21.7) & - & - \\ - & - & 2(20) & - & - & - \\ 1(3.5) & - & - & - & - & - \\ - & - & - & - & 1(20) & - \\ 6(21.4) & 1(20) & - & 3(13) & - & -\end{array}$


English Reading Ability. The successful group accounted for more respondents with "faitrly well" and "very well" reading ability. The majority of the unsuccessful group were in the "some or little ability" category.

\section{TABLE VIII}

\section{DISTRIBUTION OF ENGLISH READING ABILITY AMONG SUCCESSFUL AND UNSUCCESSFUL REFUGEES}

$\underline{\text { Ability }}$

Very wel1

Fairly well

Some or little

None

No Response
Successful

$$
\frac{\text { Viet }}{N=28} \quad \frac{\text { Cam }}{N=5} \quad \frac{\text { Lao }}{N=10} \quad \frac{\text { Viet }}{N=23} \quad \frac{\text { Cam }}{N=5} \quad \frac{\text { Lao }}{N=7}
$$

$\begin{array}{lccccc}5(17.9 \%) & 2(40 \%) & 3(30 \%) & - & - & 1(14.3 \%) \\ 14(50) & 2(40) & 5(50) & 4(17.4 \%) & 3(60 \%) & 1(14.3) \\ 9(32.1) & - & 2(20) & 16(71.9) & 1(20) & 4(57.1) \\ - & 1(20) & - & 3(10.7) & - & 1(14.3) \\ - & - & - & - & - & -\end{array}$

English Speaking Ability. 'Very respondents indicated "very we11" speaking ability. The majority of the successful group indicated "fairly we11" ability, while the majority of the unsuccessful group indicated "some or 1ittle" ability.

TABLE IX

\section{DISTRIBUTION OF ENGLISH SPEAKING ABILITY AMONG SUCCESSFUL AND UNSUCCESSFUL REFUGEES}

Ability

$$
\frac{\text { Viet }}{\mathrm{N}=28} \stackrel{\frac{\text { Successful }}{\mathrm{N}=5}}{\frac{\text { Lam }}{\mathrm{N}=10}} \quad \frac{\text { Viet }}{\mathrm{N}=23} \quad \frac{\text { Unsuccessful }}{\mathrm{N}=5} \quad \frac{\text { Lao }}{\mathrm{N}=7}
$$

Very we11

Fairly well

$$
\begin{array}{cccccc}
- & 2(40 \%) & - & - & - & - \\
17(60.7 \%) & 2(40) & 8(80 \%) & 3(13 \%) & 2(40 \%) & 2(28.6 \%) \\
11(39.3) & 1(20) & 2(20) & 16(69.6) & 2(40) & 3(42.8) \\
- & - & - & 4(17.4) & 1(20) & 2(28.5) \\
- & - & - & - & - & -
\end{array}
$$

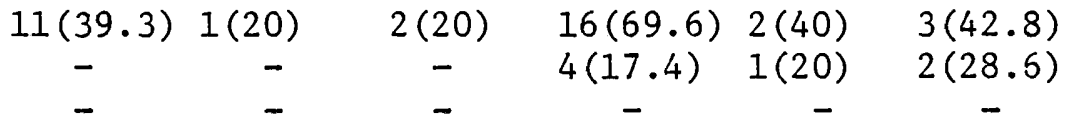$$
\text { None }
$$

No Response 
Length of Stay in America. The vast majority of both successful and unsuccessful groups indicated a length of stay in America of 1-2 years.

\section{TABLE X}

DISTRIBUTION OF LENGTH OF STAY IN AMERICA AMONG SUCCESSFUL AND UNSUCCESSFUL REFUGEES

Length of Stay

$$
\frac{\text { Viet }}{N=28} \quad \frac{\text { Successful }}{N=5} \quad \frac{\text { Lao }}{N=10}
$$

$$
\frac{\text { Viet }}{\mathrm{N}=23} \frac{\text { Unsuccessful }}{\frac{\text { Cam }}{N=5}} \quad \frac{\text { Lao }}{N=7}
$$

Less than 1 year

1 - 2 years

$\begin{array}{lccccc}- & - & - & 2(9 \%) & - & - \\ 21(75 \%) & 4(80 \%) & 8(80 \%) & 16(82) & 4(80 \%) & 7(100 \%) \\ 1(04) & 1(20) & 2(20) & 5(17.9) & 1(20) & - \\ 1(04) & - & - & - & - & - \\ - & - & - & - & - & -\end{array}$

Desire to Return Home. Differences in this item tended to exist between the ethnic groups rather than between the successful and unsuccussful groups. For the Vietnamese, a clear majority indicated a desire to return home. The Cambodians and Laotians, for the most part, indicated no desire to return home.

\section{TABLE XI}

DESIRE TO RETURN HOME AMONG SUCCESSFUL AND UNSUCCESSFUL REFUGEES

$\underline{\text { Response }}$

$$
\frac{\text { Viet }}{N=28} \frac{\text { Successful }}{\frac{\text { Cam }}{N=5}} \frac{\text { Lao }}{N=10} \quad \frac{\text { Viet }}{N=23} \quad \frac{\text { Unsuccessful }}{\frac{\text { Cam }}{N=5}} \quad \frac{\text { Lao }}{N=7}
$$

$\begin{array}{lllllcc}\text { Yes } & 22(82.1 \%) & 2(40 \%) & 5(50 \%) & 16(78.3 \%) & 1(20 \%) & 2(28.6 \%) \\ \text { No } & 5(17.9) & 3(60) & 4(40) & 6(21.7) & 4(80) & 8(71.4) \\ \text { No response } & 1(.04) & - & 1(10) & - & - & -\end{array}$

Indicators of Successful Resettlement

The tabulated data for this section of the major phase questionnaire 
can be found in Appendix B.

Housing. In terms of owning a home, the majority of respondents in each Indochinese group indicated they did not own their home. The Vietnamese were more likely, however, to own their homes, compared to the Cambodians and Laotians. Between successful and unsuccessful groups, more successful respondents tended to own homes.

The vast majority of Indochinese live with their families. Between successful and unsuccessful groups, only the Vietnamese group indicated differences. More unsuccessful Vietnamese did not live with their families.

Transportation. Most Indochinese refugees own a car and have a driver's license. Between successful and unsuccessful groups, more successful respondents possessed a car and a driver's license.

Employment. Considerably. more successful respondents have jobs. More Vietnamese and Laotians tended to have jobs compared to Cambodians.

The majority of those respondents who had jobs felt their present jobs were not suited to their levels of education and skills. A majority of those holding prior professional vocations indicated that they were not licensed to practice.

The number of respondents having job training was split almost evenly among the groups.

Education. A large majority of the respondents reported having ESL training. There were very little differences to be found among the groups.

Family-Friends. Successful respondents were much more likely to have American friends than unsuccessful respondents. Among the three ethnic groupings, there were little differences.

Culture maintenance. 'The vast majority of Vietnamese and Laotian 
respondents reported active practice of their religion. Little difference existed among successful and unsuccessful groups with the exception of Cambodian respondents. Successful Cambodians reported active practice while unsuccessful respondents reported no active practice.

Participation in cultural activities was characteristic of more successful respondents than unsuccessful respondents. More Vietnamese were Iikely to report non-participation than Cambodians or Laotians.

Finances. Successful respondents were much more likely to possess bank accounts than unsuccessful respondents. The Vietnamese and Laotians tended to report possession of bank accounts moreso than Cambodians.

Insurance. Successful respondents overwhelmingly were much more likely to have purchased health and auto insurance than the unsuccessful respondents.

Medical and health services. Responses to the question, "Do you have access to medical and health services?" were split among the groups. Little difference existed between successful and unsuccessful groups.

Recreation and leisure activities. More Vietnamese and Laotian respondents reported participation in recreational and leisure activities than Cambodian respondents. Among successful and unsuccessful groups, successful respondents were more likely to participate in recreational and leisure activities.

Residency status. The majority of respondents have not applied for permanent residency status. Among successful and unsuccessful groups, however, the more successful respondents reported applying for permanent residency. A large majority of respondents indicated an unwillingness to change their names to a more Americanized form. 
Attitudes and Perceptions. Toward Social. Services

The tabulated data for this section can be found in Appendix B. Thoughts of being on public assistance. The number of "no responses" to the questions in this section tended to outnumber the actual responses. The reserachers felt a need to disregard these findings in light of the low response rate.

Knowing where to go for help. The successful respondents, in general, were more aware of where to get help with medical and health problems, welfare problems, employment problems, and school-related problems. The majority of respondents did not know where to get help for race discrimination problems, and marriage problems.

Experiences with social service agencies. Most successful respondents felt agency workers understood their problems and treated them respectfully. A majority of the respondents reported that agency workers were not instrumental in locating living areas or jobs.

Most respondents in all groups indicated having language and communication problems with social service agencies, along with problems due to cultural differences.

Barriers to resettlement. A majority of respondents in all groups indicated that racial discrimination sometimes affected their resettlement in the United States. More successful respondents reported racial discrimination as having always affected their resettlement.

Most respondents in all groups reported some pressure in taking a job. Very little differences existed between successful and unsuccessful groups.

Success attained. Most respondents in all groups reported having 
attained some success in their life in the United States at this point in time.

More successful respondents reported "very much success" than unsuccessful respondents.

\section{STATISTICAL ANALYSES}

A one-way analysis of variance was performed on the variables of the major phase survey. The successful group was compared with the unsuccessful group within each. Indochinese sample. Due to the small numbers of respondents, very few significant relationships were reported. For the Vietnamese group, "English speaking ability" was found to be significantly different for the successful and unsuccessful groups ( $F=5.17, p<5 \%)$, as was "I know where to go for marriage problems" $(F=4.16, p<5 \%)$. For the Cambodian group, "I have had ESL training" indicated significant differences between successful and unsuccessful groups $(F=6.00, p<5 \%)$, along with "I know where to go for medical-health problems" (F=5.33, $p<5 \%)$. For the Laotian group, "I own a home" was significantly different for successful and unsuccessful groups $(F=6162, p<5 \%)$, as was "I am not licensed to practice my professional vocation" ( $F=5.20, p<5 \%)$. 
CHAPTER V

SUMMARY AND CONCLUSIONS

The data gathered in this study provides some insight into the resettlement status of the Indochinese refugee residing in the Portland area. Patterns depicting successful resettlement, as defined by the refugees themselves, were suggested by the data. Also suggested were patterns of demographic characteristics of the refugee; and patterns regarding their attitudes and perceptions toward social service programs and barriers toward successful resettlement.

\section{PRELIMINARY PHASE}

Being successfully resettled meant, for a sample of Indochinese refugees, having access to those items which foster social mobility, financial security and employment security. It meant being able to get around -- owning a car, a means of transportation, and being able to communicate -- learning English. Successful resettlement, according to the refugees, also meant financial security -- having a job, bank accounts, having insurance, owning a home, as we11 as securing permanent residency status and U.S. citizenship. Employment security also contributed to successful resettlement, according to the refugees -- having job training, being recertified or relicensed, and having a job suitable to one's skills and education levels.

In line with these findings, major barriers to successful resettlement, according to the refugees, included not knowing encugh English and 
not haying a good job. Among different Indochinese groups, the Cambodian graup reported many more barriers than either the Vietnamese or Laotian groups. This implies that Cambodians are having a harder time than the Vietnamese or Laotians in resettling in the Portland area. This finding can be compared to that of Edith Lenart, who observed that Cambodians in Paris found it more difficult to adapt to the host culture than the Vietnamese or Laotians. ${ }^{1}$

MAJOR PHASE

\section{Demographic Characteristics of the Respondents}

The typical Vietnamese or Cambodian respondent was a married male in his thirties. He was either Buddhist or Catholic, and was likely to have had a military-related occupation in his homeland. He can speak or read "some of little English." His typical length of stay in America has been "less than $1-2$ years."

The typical Laotian respondent was a married male in his twenties. He is likely to be Buddhist and have had a military career. He can speak or read English "fairly well." He has been in America for 1-2 years.

The typical successfully resettled respondent could speak and read English "fairly well" or "very well." He or she also tended to have a professional or white-collar occupation in his or her homeland. These observations support those of James Vander Zanden and Jerold Heiss on premigration traits related to immigrant adaptation. Heiss found that migrants who were socially mobile and of young adult age at the time of migration tended to adapt to the host culture more readily than migrants who were not socially mobile and not of young adult age. ${ }^{2}$ Vander Zanden 
found that rapid assimilation or adaptation was influenced by the migrant's previous occupational level: The higher the occupational level, the more rapid the adaptation. 3 .

Indicators : of Successful ResettIement.

The group of successfuly resettled refugees indicated a greater degree of adaptation to American culture. They were more likely to own a home, own a car, and have a driver's license; be more likely to have a job; have American friends, participate in cultural activities, have bank accounts, have health and auto insurance, have access to medical/ health services, and have applied for permanent residency. These findings are in line with those of the preliminary phase, in which refugees indicated successful resettlement meant social mobility, financial security, and employment security.

\section{Attitudes and Perceptions}

Data gathered in this section suggested patterns about the refugees' knowledge of social service resources; their experiences with social service agencies; and thoughts on barriers to successful resettlement.

The refugees in this study were aware of resources for help with basic needs. The vast majority indicated they knew where to obtain help for medical and health problems, employment problems, and schoolrelated problems. They indicated not knowing where to get help for more interpersonal, complex problems such a race discrimination and marital problems. Some speculation can be made about this finding. Among the refugees, knowledge about resources for basic needs tends to be considered general knowledge and easily transferred by word of mouth. 
Regarding more complex, interpersonal needs, however, knowledge of resources or discussion of these: problems tends to remain within the confines of the individual and family -- the Indochinese tend not to be encouraged to seek help from others outside the family circle.

Some patterns emerged from the data regarding the refugees' experiences with social service agencies. Refugees, for the most part, felt they were treated respectfully by the social agency workers. But, they indicated that there were frequent language and communication problems between the workers and themselves. These problems, however, did not seem to deter people from obtaining help from the social agencies. The majority of the refugees indicated they did nor locate living places or jobs thraugh the social agnecies. They did indicate, however, that they received some pressure from the agencies to take a job that was being offered to them.

A majority of the successful refugees seemed to be more sensitive to the effects of racial discrimination as a barrier to successful resettlement. It could be possible that on their way to achieving social mobility, and financial and employment security, these refugees came up against more racial discrimination than the unsuccessful group of refugees.

\section{FURTHER RESEARCH}

This study was merely an exploratory study, not designed to prove or disprove any existing theories. Further research is necessary to come to any definite conclusions concerning the refugees from Vietnam, Cambodia, or Laos; and regarding, for example, the disadvantageous facets of accultu- 
ration, since this study illustrates that successful acculturation means adapting middle class yalues. The research has posed and uncovered some possible patterns or relations regarding the resettlement status of the Indochinese refugees in the Portland area, and their attitudes and perceptions of American social services.

For further studies to be effective, a larger sample size. should be obtained. Few significant patterns could be uncovered in the major phase due to the small numbers of respondents. A larger number of questionnaires should be distributed in order to receive a larger number os responses.

Question construction could be improved. Careful examination of the questions should be undertaken to lessen the ambiguity posed by some of them. Translations should be rigorously reviewed by several translators, testing for differing interpretations. Although not all problems of question construction would be eliminated, following these steps could lessen or avoid problems with the present construction.

Those patterns suggested by this study should be explored more thoroughly.

Longer-term research should be undertaken on the Indochinese refugees who have resettled in America. The group is unique, not only because they are refugees, but because they are much different from other previous refugees groups that have settled in America. Additional studies of adjustment or resettlement could be undertaken over the next several years.

Studies of Indochinese refugees can provide valuable insights into the social service delivery systems instituted by social service agencies. 


\section{NOTES}

${ }^{1}$ Edith Lenart, "After War, Another Battle," Far Eastern Economic Review, April 29, 1977, p.22.

${ }^{2}$ Jerold Heiss, "Factors Related to Immigrant Assimilation: PreMigration Traits," Human Organization, 26, 1967, p. 265.

3 James W. Vander Zanden, American Minority Relations (New York: Ronald Press, 1963), pp. 277-280. 
CHAPTER VI

COMMENTS

Some of the Indochinese refugees who responded to the major phase survey expressed themselves in the "Comments" section provided at the end of the questionnaire. The comments reveal emotions and needs held by the refugees in their lives in America.

Many of the refugees listed needs they felt in their resettlement in the United States. The need for education, especially English language skills, was a frequently expressed theme:

"The general lack of education has been a real problem for us. My wife wants to learn more English so that she can effectively communicate with American people" (Laotian)

"I'd like to see more English classes for the Vietnamese, please." (Vietnamese)

"Public assistance will be provided for a limited time, so I need to learn more and have a specific skill to earn a living and support my family." (Laotian)

"I feel that the larger families have the difficulties in resettlement. Sometimes I don't feel. I could make it because of language barriers." (Laotian)

Other frequently expressed thoughts were those concerning the lack of social services:

\footnotetext{
"I'd like to find out more about health and social services in America" (Cambodian)

"I have a large family with a limited amount of income and the public welfare office does not provide enough money to meet my expenses." (Laotian)

"I have problems with housing, employment, and so on" (Cambodian)
} 
"Sometimes I wonder if the social service workers only work hard because of rules and regulations stated in their job descriptions." (Laotian)

"I don't know how to get around the city...especially when I need to go to the hospital. I also need someone to translate for me at times." (Vietnamese)

"Before I moved to Portland, I had a sponsor; we are without one now. We need someone to help us with a number of things. I'd like to apply for permanent residency now." (Vietnamese)

"Family expenses can only be provided for and met if we remain on welfare, although this is not our choice" (Laotian)

"I have two brothers and three children; but I don't have my husband with me. The government helped me to learn more English six months ago, but now every program for the refugees has been terminated. That was an unthoughtful action to take. However, I understand that a four year extension of the programs is being planned. Perhaps I'll get more out of the services next time. I need more English training. At times I am very sad, I think about my future...this is very frustrating. I think I need someone to help me find a part-time job and also get to school." (Vietnamese)

Regarding socio-cultural factors, the following thoughts were prevalent:

"In America, it is difficult to locate the food ingredients used in Laotian cooking." (Laotian)

"I'd like to learn more about cultural values and ways to get along better in America." (Cambodian)

Many refugees expressed thoughts of interpersonal frustration, lone-

liness and other psychological concerns:

"I think the Indochinese war has done a lot to damage us. We, the Vietnamese people in America, have begun to split off into small groups. There is no togetherness, no more fiendships and family deterioration is beginning." (Vietnamese) 
"It is unfair for the Vietnamese who have job.skills and who are unable to find jobs. This has been the most frustrating experience of my life." (Vietnamese)

"I am living by myself in America, and hoping it is only temporary. I hope to return home some day because my wife and children are still there. If my dream of returning home doesn't come true, I hope my family can come and join me here. For the time being, I do not need anything because I am too homesick to think and to do anything...I just don't know." (Vietnamese)

"Thank you very much for the questionnaire you sent me. That was nice of you..getting something from you means a lot to me. It means you care about me. I am very lonely. Every day, I have no one to talk to. Welfare is the only source of income that I have. I need more help than this. A lot of times I don't feel good because people talk about me. They think I have alot of gold and money with me...in reality, I don't. I don't think anyone likes me anymore. I hope you can help me. If you don't believe me, just drop by to see me and my family. I'd like to have some ideas to help me feel better. I hope you will come and help me. If there is anything wrong in what I have said, please forget about it." (Cambodian)

"As I look around me, I can see the American government has helped me, but I don't understand how come my fellow Vietnamese don't help each other like they did back home. There are many Vietnamese that do alot of nice talking, but little action or sincerity follows all their talk." (Vietnamese) 


\section{A SELECTED BIBLIOGRAPHY}

Beery, Galen. "Special Report, Indochina Refugees: Resettlement Progress." The Christian Century, October 1976, p. 931.

Breton, Raymond and Maurice Pinard. "Group Formation Among Immigrants: Criteria and Processes." Canadian Journal of Economics and Political Science, 26, 1960, p. 465.

David, Henry P. "Involuntary Internation Migration: Adaptation of Refugees," International Migration, 7, 1969, p. 34.

Eisenstadt, S. N. The Absorption of Immigrants. New York: Free Press, 1955 .

Eitinger, L. "The Incidence of Mental Disease Among Refugees in Norway." Journal of Mental Sciences, 105, 1959, p. 326.

Gordon, Milton M. Assimilation in American Life. New York: Oxford University Press, 1964.

Heiss, Jerold. "Factors Related To Immigrant Assimilation: Premigration traits." Human Organization, 26, 1967, p. 265.

Holborn, Louise W. Refugee: A Problem of Our Time. United Nations High Commissioner for Refugees, 1951-72: n.p., n.d.

Holme, Richard, ed. Abnormal Psychology: Current Perspectives. Del Mar, California: Communications Research Machines, Inc., 1972.

Immel, Jean. Vietnamese and Cambodian Study. Unpublished report, Portland State University, 1977.

Lenart, Edith. "After War, Another Battle." Far Eastern Economic Review, April 29, 1977 , p. 22.

Lin, Keh-Ming, Laurie Tazuma, and Minoru Masuda. "Adaptational Problems of Vietnamese Refugees, Part I: Health and Mental Health Status." Unpublished report, University of Washington, 1977.

Murphy, H. B. M. Flight and Resettlement. Lucerne: C. J. Bucher, Ltd., 1955.

Naditch, Murray P. and Richard Morrissey. "Role stress, personality and psychopathology in a group of immigrant adolescents." Journal of Abnormal Psychology, 85, 1976, p. 43. 
Rogg, Eleanor M. The Assimilation of Cuban Exiles: The Role of Community and Class. New York: Aberdeen Press, 1974.

Sechectman, Joseph B. The Refugee in the World: Displacement and Integration. New York: A. S. Barnes, 1963.

Shaplen, Robert. "A Reporter At Large." The New Yorker, Sept., 1977, p. 33.

Simsopson, John. "The Refugee Problem." Annals of the American Academy of Political and Social Science. May 1939, p. 45.

Spiro, Melford E. "The Acculturation of American Ethnic Groups," American Anthropologist, 57, 1955, p. 1243.

Stoessinger, "Refugees," Encyclopaedia Brittanica, 1973 ed.

The Report of the Uncle Counselor. Southeast Asian Mental Health Project. Los Angeles: October 1976 - July 1977.

U. S. Cong. A Study Mission Report Prepared for the Committee on the Judiciary. 95th Cong., 1st sess., December 1977.

U. S. Department of HEW Task Force For Indochinese Refugees. Report To The Congress. Washington, D.C.: Sept. 15, 1975.

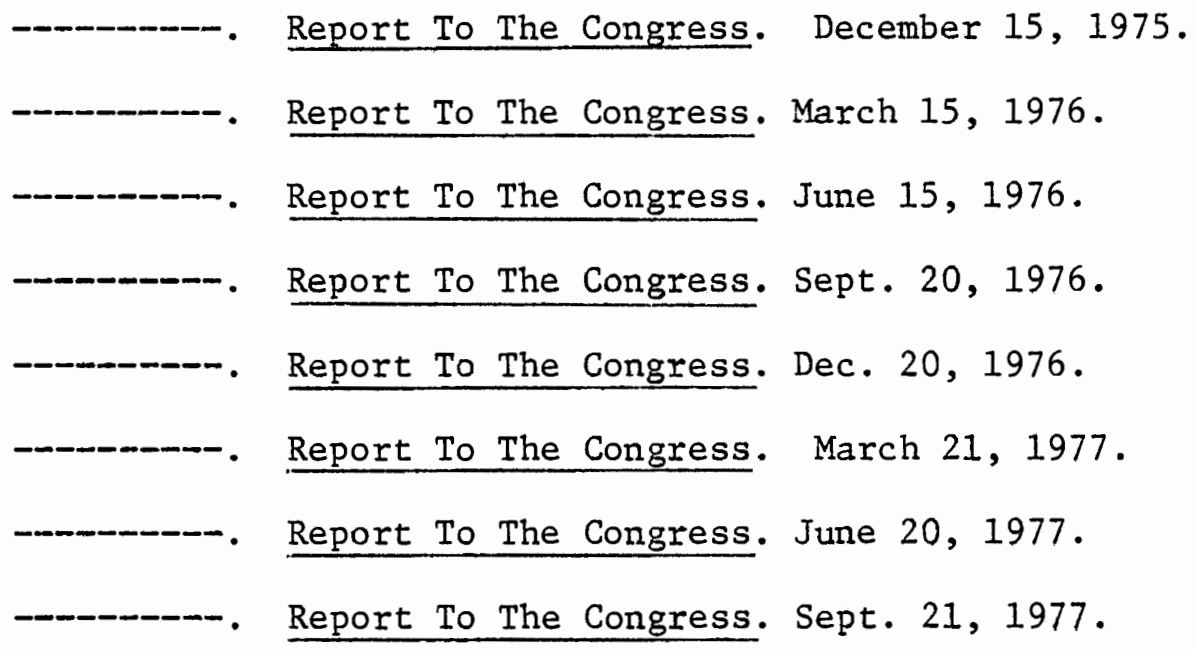

Vander Zanden, James W. American Minority Relations. New York: Ronalds Press, 1963.

Weinstock, S. Alexander. "Role Elements: A Link Between Acculturation and Occupational Status." British Journal of Sociology, 14, 1963.

Williams, Robin. American Society: A Sociological Interpretation. New York: Knopf, 1951. 
APPENDIX A

QUESTIONNAIRES 


\section{PRELIMINARY PHASE SURVEY}

We are graduate students from the School of Social Work at Portland State University, conducting a research project on Indochinese refugees.

We are interested in how you feel about your current living situation and lifestyle. Please help us to gain some understanding in these matters by honestly responding to the following questionnaire. Please feel free to express your true feelings. The study will be resourceful to the State and Federal governments in terms of policy making for all the Indochinese here.

Resettlement conditions

Please mark those items below which you feel you would personally need to gain in order to consider yourself successfully resettled in America.

1. Own a home

2. Own a car

3. Have a job equal in status to

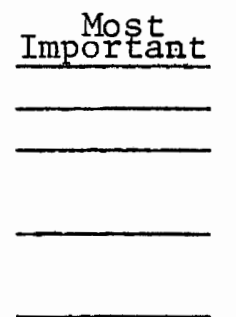

4. Graduating from a 4-year

U.S. college

5. Living in a home or apartment by yourself

6. Belonging to a cultural organization

7. Having bank accounts

8. Having health insurance

9. Having access to legal services

10. Having access to family planning services

11. Having access to medical services

12. Being able to afford leisurerecreation activities

13. Having cultural foods available

14. Rent a house or apartment

15. Ability to ride a bus

16. Having a job suiting your education

17. Graduating from a $2-y r$. U.S. college

18. Living in a home or apt. with your family

19. Being able to practice your religion

20. Having home or life insurance

21. Ability to aquire an attorney

22. Becoming accustomed to American
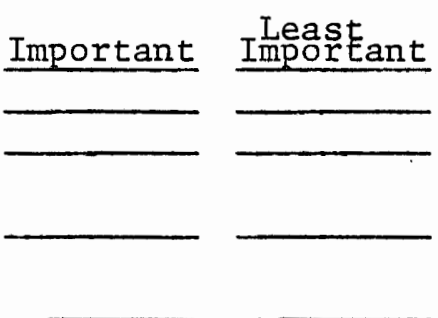
foods

23. Live in a rural area
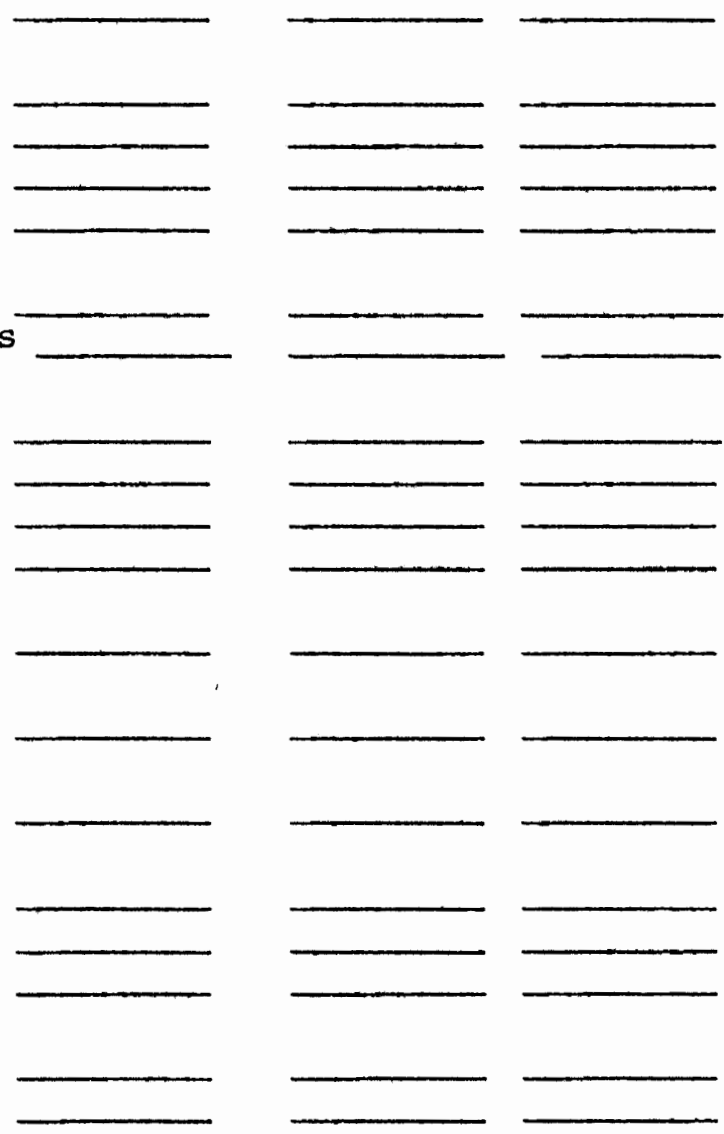
24. Have an Oregon state drivers Iicense

25.. Having any that provides an income to live on

26. Gaining recertification

27. Having some American friends

28. Celebrating and participating in cultural events

29. Having credits to get loans and charge accounts

30. Obtaining permanent residency

31. Having a large family (more than 3 children)

32. Having no job and being on welfare

33. Having ESL training

34. Obtaining job training

35. Obtaining U.S. citizenship

36. Having auto insurance
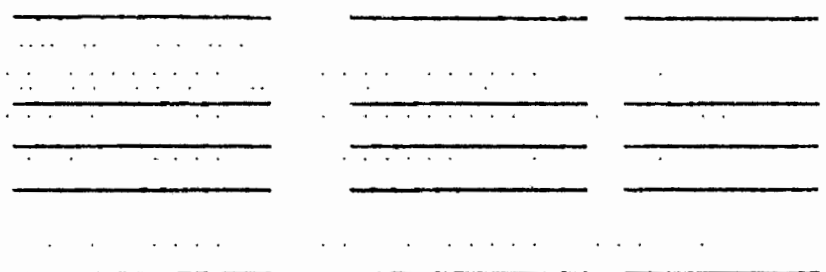

Barrier conditions: Please mark $X$ next to the items which you feel most likely prevents you from attaining those items marked in Part I of the questionnaire.

1. Not knowing enough English

2. Not having a good job

3. Racial discrimiantion or prejudice

4. Not having enough job training

5. Job discrimination or prejudice

6. Lack of recertified Indochinese degrees

7. Finding jobs to be scarce

8. Having cultural misunderstandings with employer

9. Lack of financial aid for schooling

10. Not having adequate housing

11. Not having family members in America

12. Not having an organized cultural association

13. Finding discrimination among Ioan and credit orgs.

14. Having different religious and cultural ideas

15. Not having basic cultural necessities (food, clothing)

16. Not obtaining permanent residency

17. Want to return home someday 
VIETNAMESE PRELIMINARY SURVEY

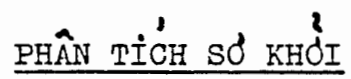

Chúng tôi là sinh viên tớt nghièp ban dich vu xã hồi (Social Work) tai Truóng Portland State University, dang thuc hiên mót dủ án nghièn cưu vè ngưoì ty nạ Dông Dubng.:- Quan tâm : dến cấc ban cạm nghi vè tinh trang yà loói sống hañg ñgày của qui vi. Yêu câu quý ví gilp chúng tỏi có them hieu bièt về ván déc

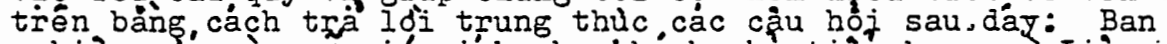
nghièn cứ này sê giúp ích cho chánh phư tièu bang va Ijèn Bang trong viêc hoạch dịn chánh sách áp dung cho tạt cá ngươi tỵ nạ Đông Dưòng.

Dieu kièn dinh cú: (Resettlement conditions)

Yêu, câu dånh dáu 1,2 hay 3 tưy theo khoang trống mà ban càn va muón có dề có thè xem như vúa ý trong sụ dịnh cư tại hoa Kÿ. 1: rât quan trọng; 2: quan trọg hay 3 : it quan trọng.

1

2 3

1. Sờ hữu chư mọt căn nha.

2. $5{ }^{2}$ hưu chu một xe hói.

3. Có viẹc làm ngang yói trính dọ bại dã có tại xú nhà.

4. Tồt nghiẹp một dạ học 4 năm.

5. Sông trong một cằn nha hay muôn mọt minh ơ appartment.

6. Gia nhạp mọt có só Ván Hóa.

7. Cọ́ mọtt trióng mục tại ngàn hang.

8. Có bảo hièm súc khoe .

9. Có ,nhơ các ső dịch vụ luạt phap.

10. Có nhó các dịch vu gia dinh.

11. Co nhó các dich vi Y Tè

12. Có thè có thơi $i^{\prime a}$ ránh giài trí

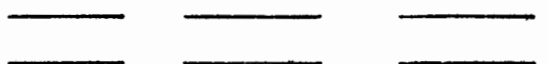

13. Có trịnh dọ vắn hóa (Vịẹt Nam, Lào, Cam Böt) những thưc ắn tinh thàn.

14. Mướn mọt căn nha hay Một chung cú. 
1

2

3

15. Có khă năng di xe Bus

16. C⿺辶̀ mòt vięc làm vói sù may

17. Tōt nghièp dai học cọng dồng tù 2 nă⿱㇒冋.

18. - Đang sỏng trong căn nhà hay sống chung cu voi gia dinh. 19. Cé thè thưc hänh tòn giáo
cuia minh.

20. Có nhà hay bão hièm nhán tho

21. Có thè mứn một luạt su.

22. Băt dâu quen dung dö àn My.

23. Sóng ò dơng quê:

24. Có bâng lái xe, ò Oregon.

25. Cọ thè nhạn bát cú cợng việc gí ma dem lại lợi túc cho. dói song

26. Iày lại dườc chúng chĩ văn bäng cua jòng Dúong tai Hoa $\mathrm{K} \dot{\mathrm{y}}$

27. Có vài bạ thân ngáiói $M \tilde{y}$

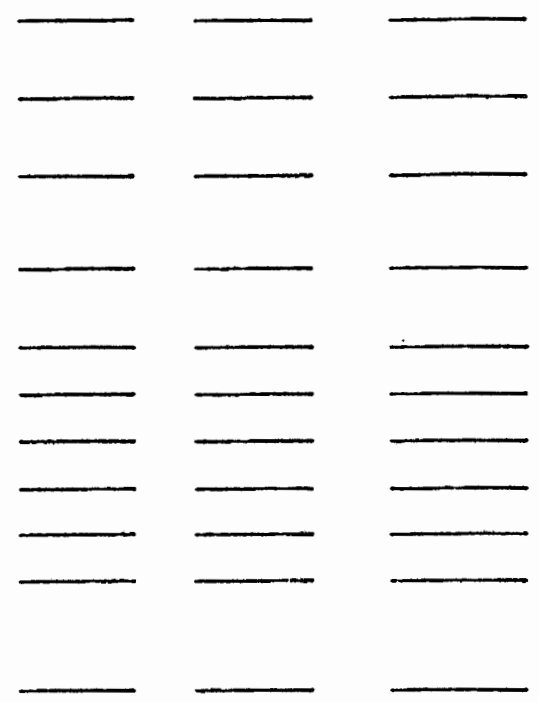

28. Du lé và tham gia nhüng hoat dợg văn ho'a $\rightarrow \delta$ ing Dióng.

29. Co.tin chí (credit) dè vay hoạc tra tien tai mọt truóng mục:

30. Châp nhận cu trí thưoing trực tai Hoa Kj.

31. Có gia dinh dông còn (trên 3 con)

32. Dang thàt nghiêp và nhạn trò xă hôi.

33. Có theo họ khóa huàn luyện Anh ngl.

34. Châp nhận thự huán còng viẹc

35. Châp nhặn trö thänh công dần Hoa $\mathrm{Ky}$.

36. Có baó hièm xe hòi.

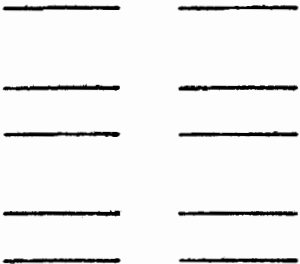


Nhứng diêu kiên tró̀ ngai:

Dánh dáu và nhửng câu hơi sau dây xác thực nhắt mà ban thày

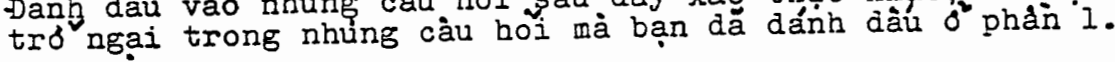

1. Không hiều dù trinh dọ Anh văn

2. Không có môt việc tót

3. Sự kỳ thị chưng tộc haytốn thương dên miñh.

4. Không có dư công việc huắn nghệ.

5. Công viềc kỳ thị hoạc bị läm tồn thúong.

6. Thiếu vằn băng và chùng chì Đông duóng.

7. Tim một còng yiẹc, thật hiếm.

8. Có sự ngốn pgủ bât aồng giứa bạn và nhân vièn "cung sơ.

9. Thiểu trọ̀ giúp tài chánh dè tiép tục viềc học.

10. Không họi dự dièu kiện dề thue nhà.

11. Không có thấn quyén ơ Hoa ky.

12. Không có mọt tồ chưc cưa Hộa Văn Hoá.

13. Tím kiếm mọt sư phân bięt rõ rẹt trong sớ tín chí haj hồ cho vay.

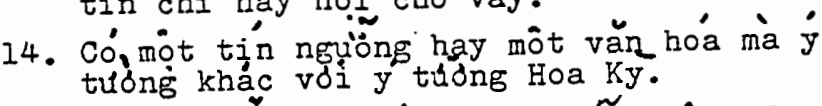

15. Khöng thè thu thâp du'òc nhung vât dung cắn ban văn hóa ơ dây (thíc an, quăn ao, v.v...

16. Không châp nhận cù ngự thứ̛̀ng trú.

17. Nuấn trỏ vè quê hương mọt ngày gần dày. 


\section{CAMBODIAN PRELIMINARY SURVEY}

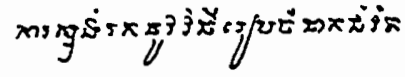

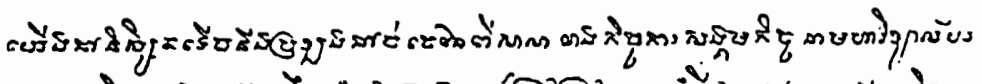

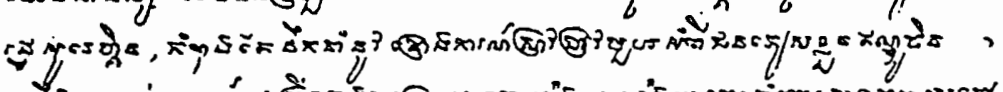

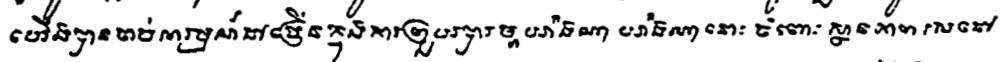

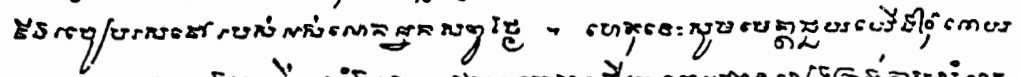

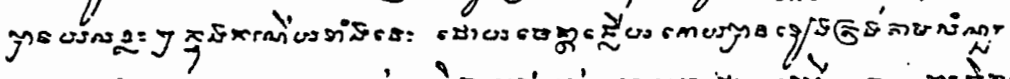

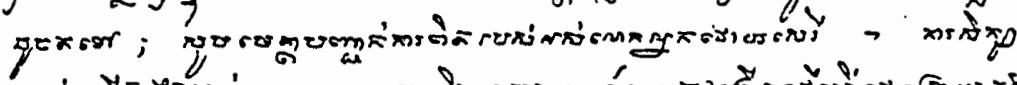

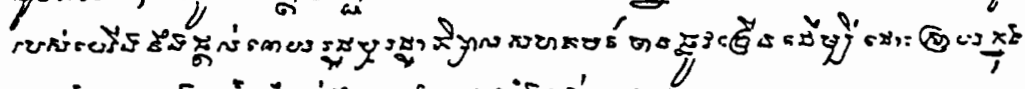

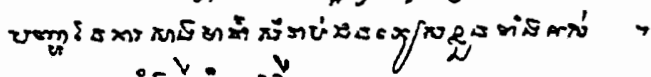

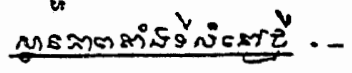

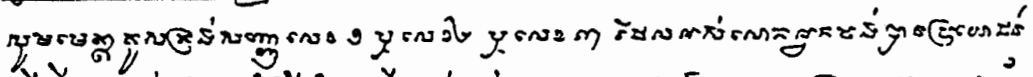

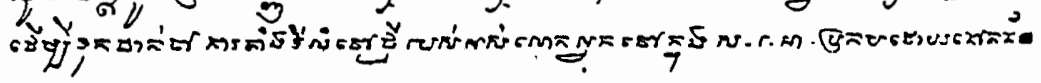

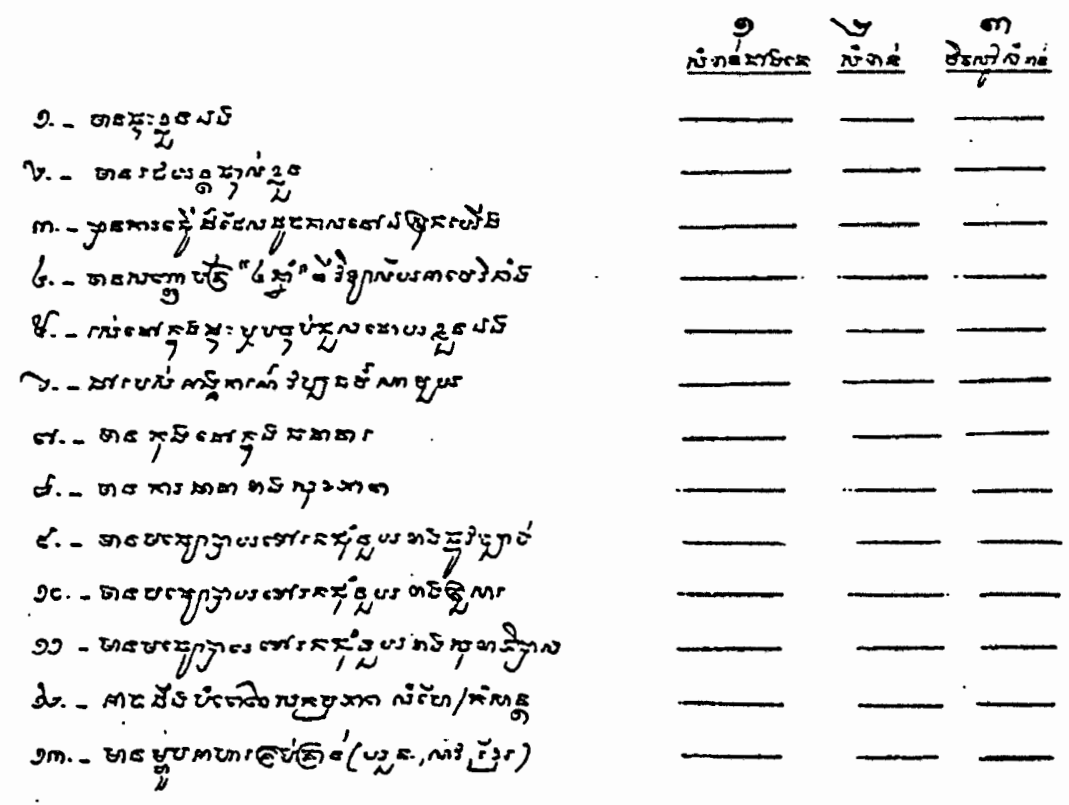




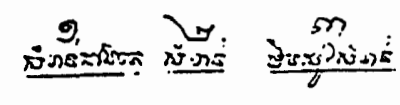

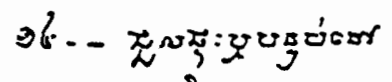

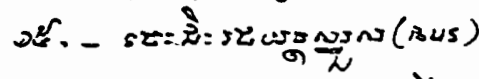

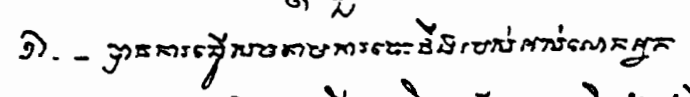

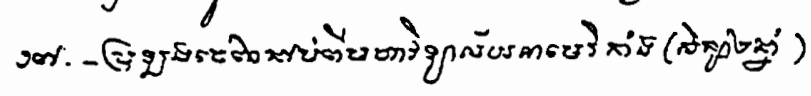

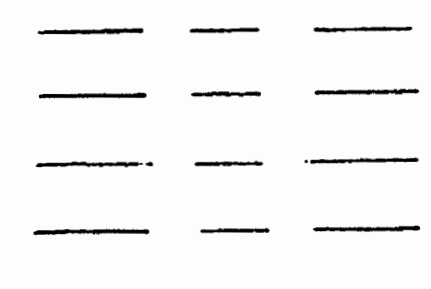

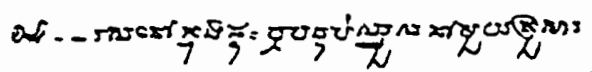

06. - -

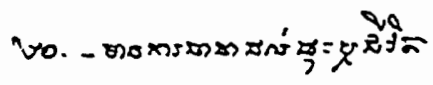

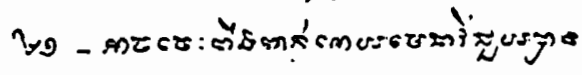

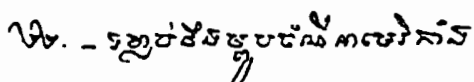

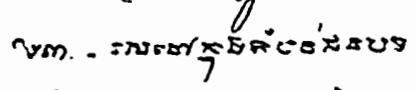

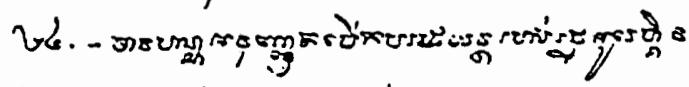

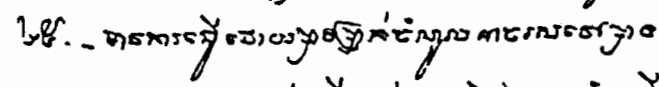

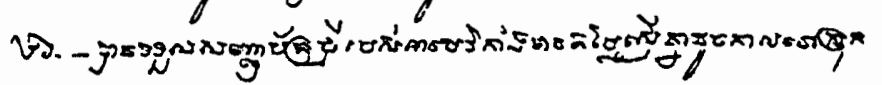

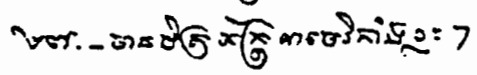

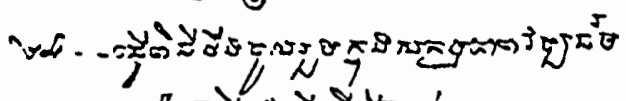

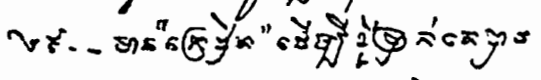

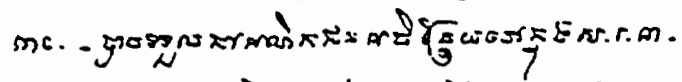

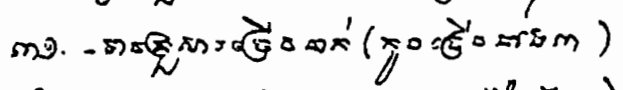

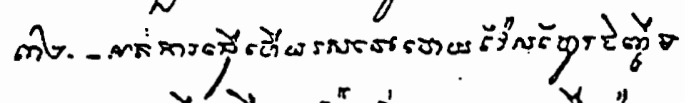

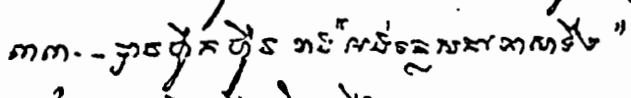

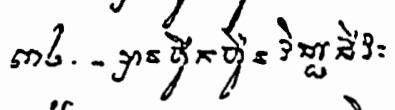

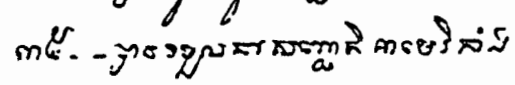

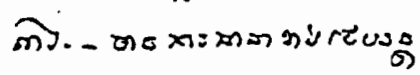




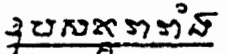

पण

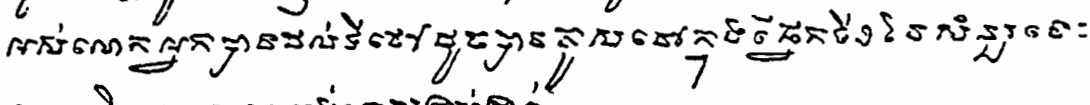

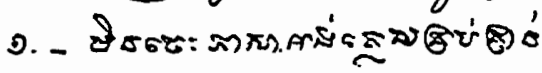

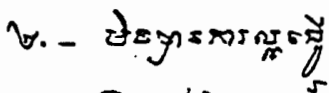

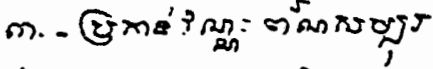

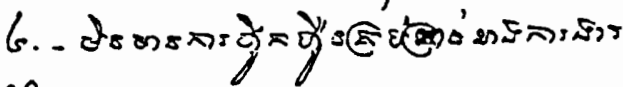

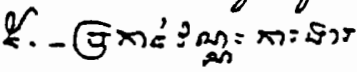

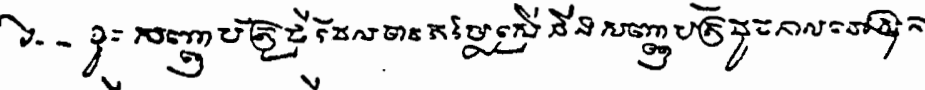

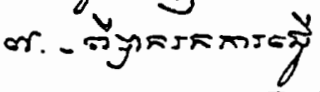

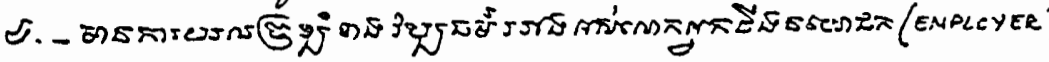

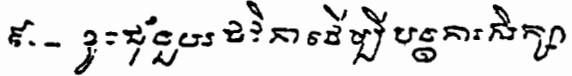

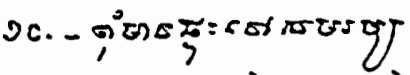

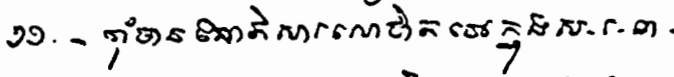

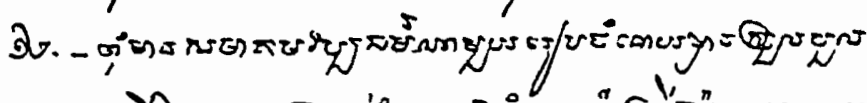

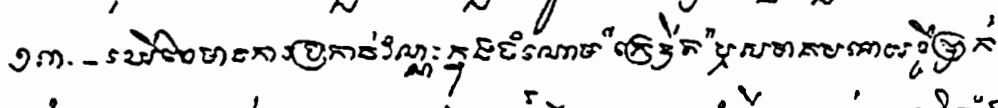

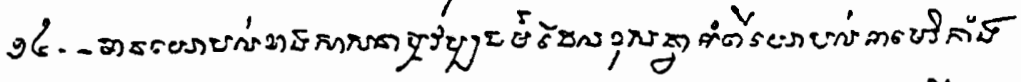

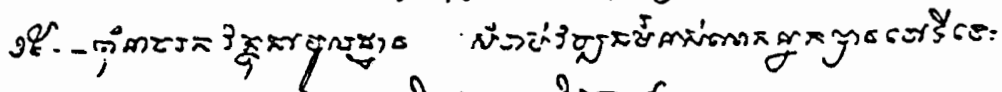

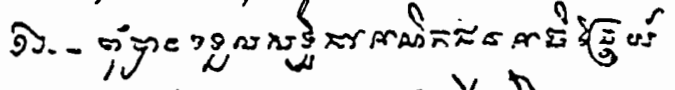

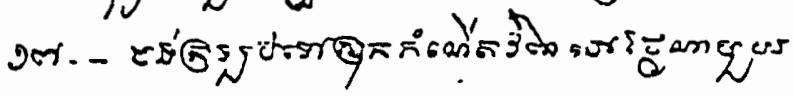




\section{LAOTIAN · PRELIMINARY SURVEY}

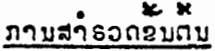

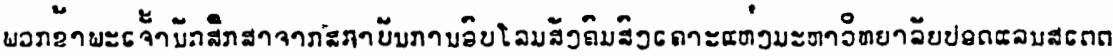

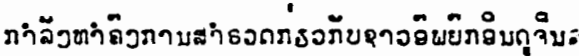

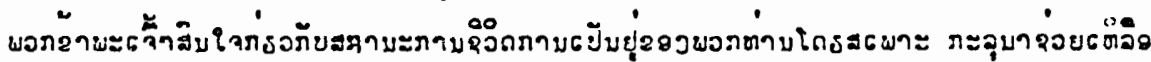

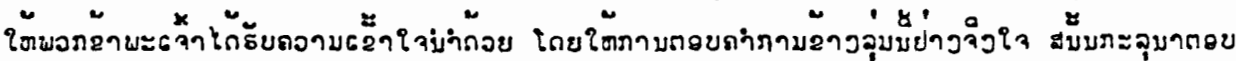

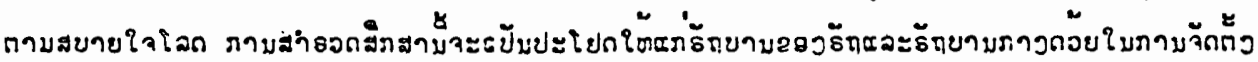

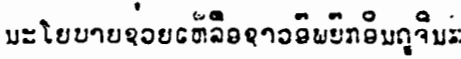

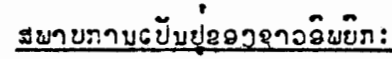

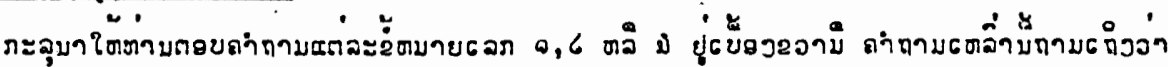

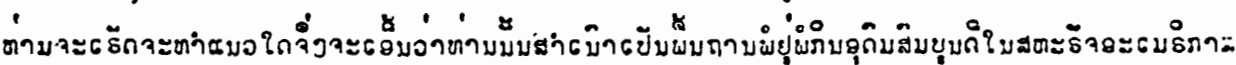

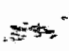

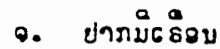

6. ยากข้ลัดร

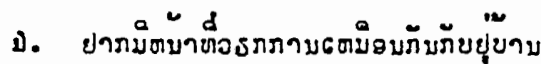

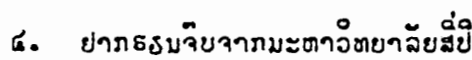

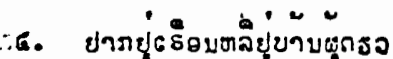

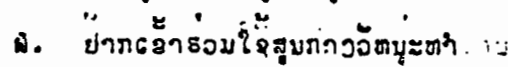

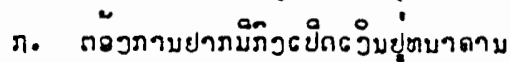

ฉ. ย่ารบัยะรับพัยฐุ้พาข

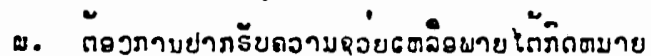

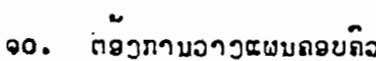

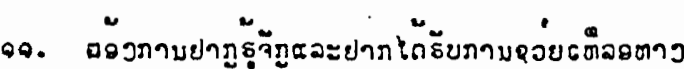
ถามถอาบธ วนธข้บ

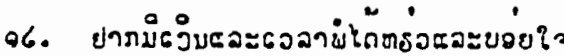

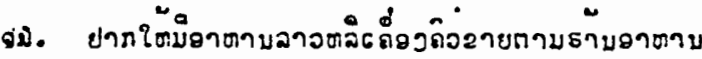
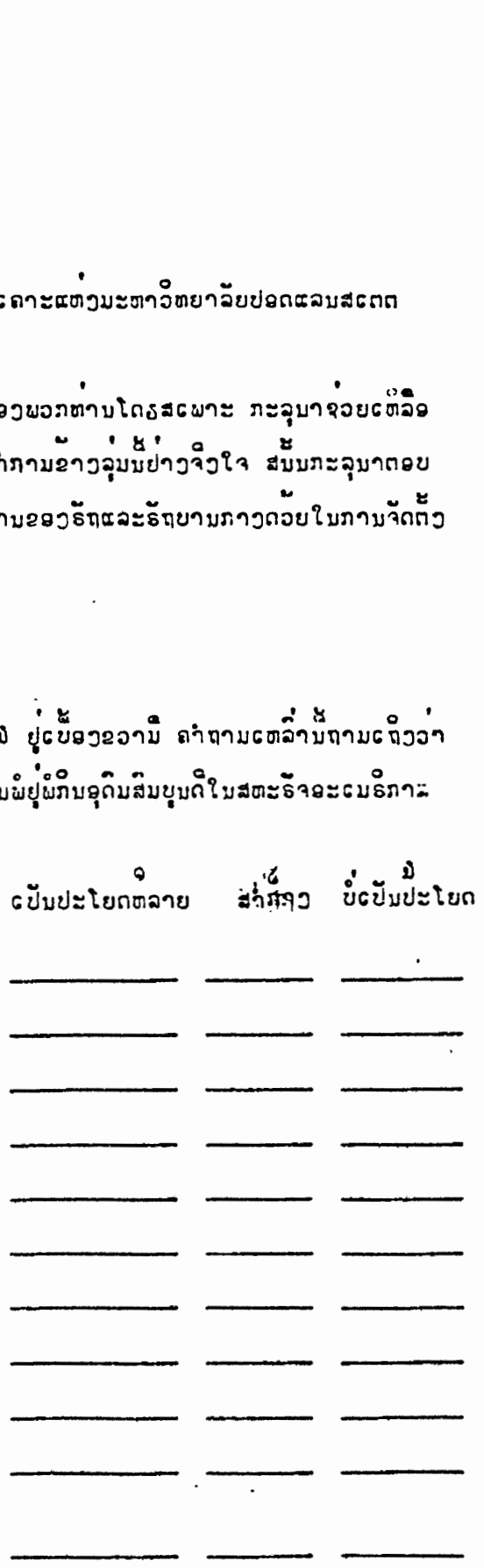


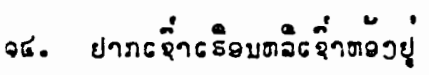

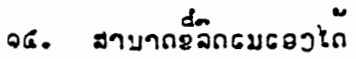

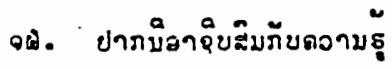

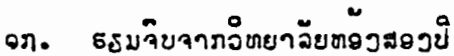

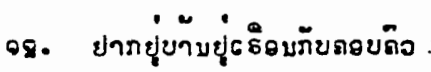

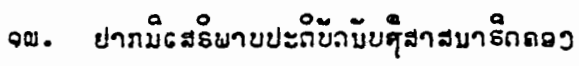

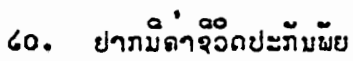

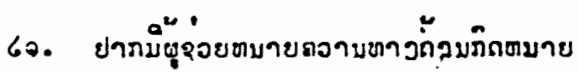

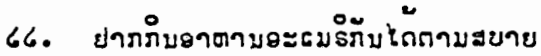

6จ. ยากยุ่บวกเมี่อง

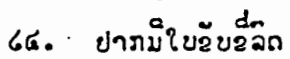

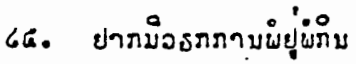

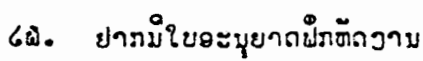

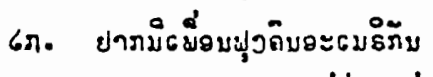

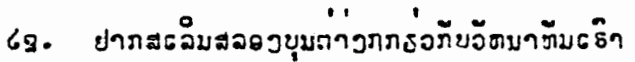

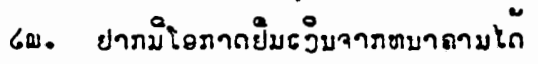

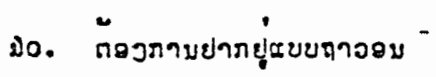

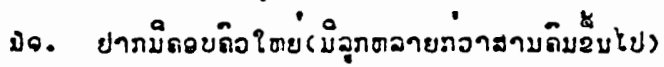

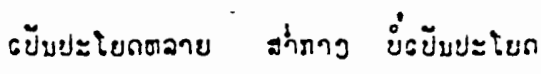

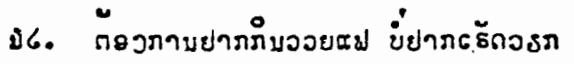

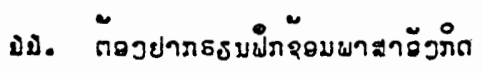

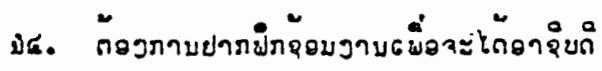

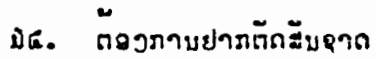

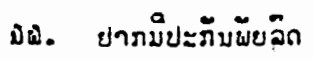

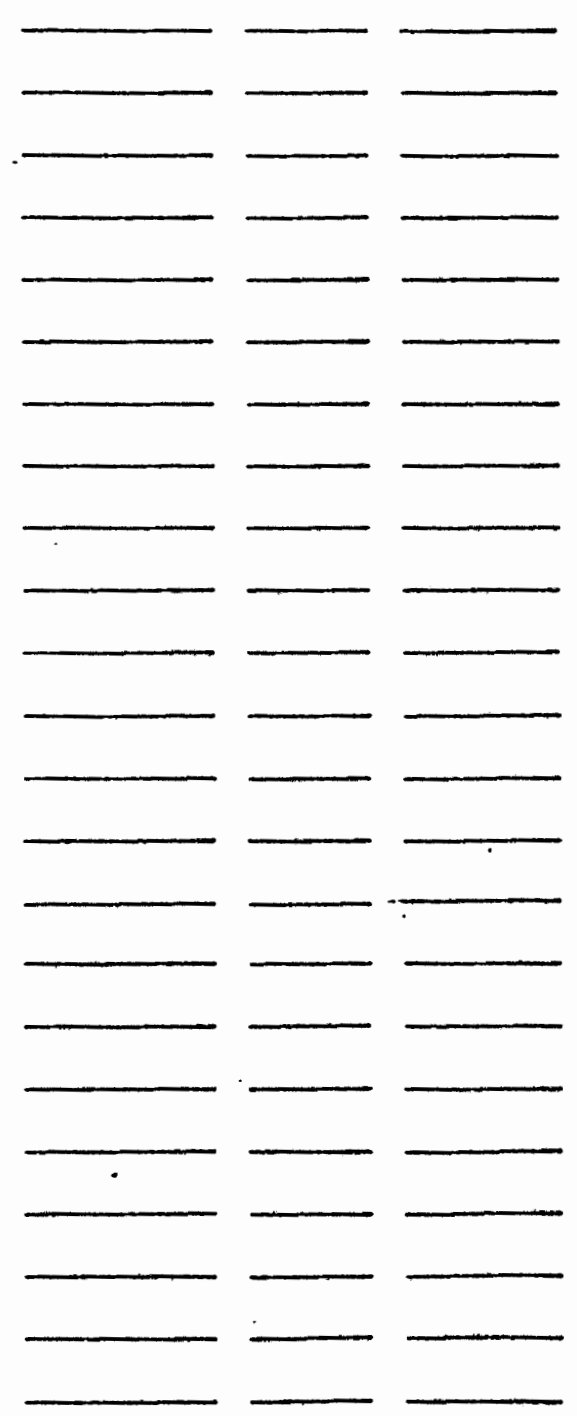




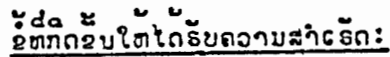

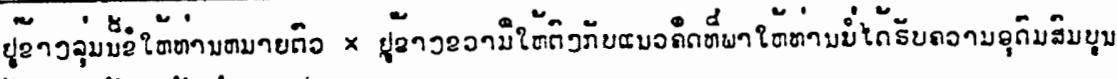

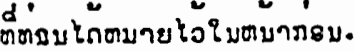

ข. บิธุวักษาดัวกำ

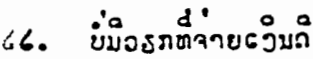

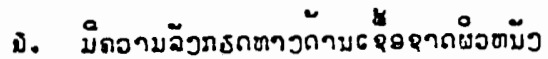

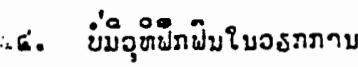

๕. มักามลัวภรกใบกาบฉจภราม

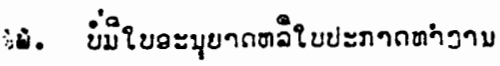

ภ. ९อภตาวรภกามข่ลต่อมี

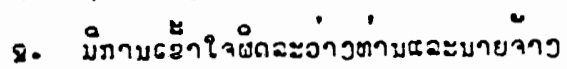

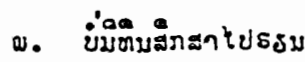

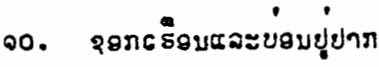

จ. ยัวราถยากฝึ้มอวมายุ่บวั

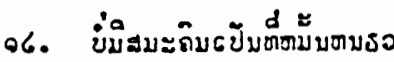

จi. มักาบลัวภรกใบภาบย์มธวัมจารยบาถาม

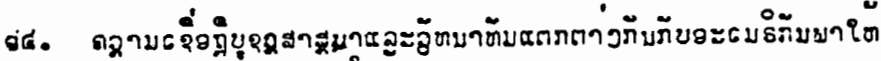

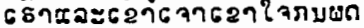

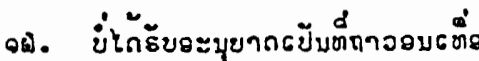

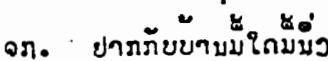




\section{MAJOR PHASE SURVEY}

We are from Portland State. University and are conducting a research project on Indochinese refugees: As you know, some special services that were desigened to meet the needs of the Indochinese have been reduced or delayed in one way or another. Many people in government and other agencies may not know exactly what kinds of needs or services interest you in order to live successfully in America. In America, one way to find out what kinds of needs or services interest you is through the use of a questionnaire or survey. By using a questionnaire or survey, you can express your opinions and ideas anonymously, in a democratic way. So, your honest answers to this questionnaire can help to determine your current and future living situations in America.

We ask that you please complete this questionnaire now. We are not asking for your name. We need your help so please feel free to express your opinions. It is urgent and important, we beg you not to throw this questionnaire away. Fill it out and mail it today, please.

Thank you very much for your time. (An envelope and a stamp are enclosed for convenience in responding to us.)

I. Personal Information

Mark X next to the items which are true for you. Please answer as many as possible.

Example: I use the bus. Yes $\mathrm{X}$ No

I have a secure job Yes No

1. What is your nationality? Vietnamese Cambodian Laotian

2. What is your year of birth?

3. What is your present marital status? Single__ Married Divorced Separated Widowed

If married, is your spouse here with you in America? Yes

4. What is your sex? Male Female

5. How long have you been in America? Less than 1 year 1-2 years 3-4 years 5 or more years

6. Can you speak English? Very we $\overline{11}$ _ fairly well some or little English none at all

7. Can you read English? Very well fairly well some or little English none at a11

8. What is your religion? $\overline{\text { Catholic }}$ Protestant Other none Buddhist Moslem

II. Current Living Situations

Mark X next to the items that are true for you. Please answer as many as possible. If you are unable to answer an item, skip it and go on to the next item. 
A.

1. Do you own a home in the United States?

2. Do you own a car?

3. Do you have a driver's license?

4. Do you have a job?

5. If you have a job, does it suit your education or skill level?

6. If you have a doctor's, dentist's, or other

$\begin{array}{ll}\text { Yes__ } & \text { No } \\ \text { Yes__ No } & \text { No } \\ \text { Yes___ N } & \text { No } \\ \text { Yes__ }\end{array}$
professional degree, have you been licensed to practice your vocation in the United States?

7. Have you had ESL training?

Yes__ No

8. If you had ESL training, how long was it? Less than 1 year 1-2 years more than 2 years

9. Do you have American friends?

10. Do you have a bank account?

11. Do you have health insurance?

12. Do you have auto insurance?

13. Do you have access to medical services?

14. Have you applied to be a permanent resident?

15. Are you willing to change your name to make it more Americanized?

B.

1. Do you live with your family?

2. Do you actively practice your religion?

3. Do you plan to return home someday?

4. Are you working actively to return home?

5. Have you had job training?

6. If you had job training, how long was it? Less than 1 year 1-2 years more than 2 years

7. Do you participate in cultural activities?

8. Are you able to participate in recreational

\begin{tabular}{|c|c|}
\hline Yes & No \\
\hline Yes & No \\
\hline Yes & No \\
\hline Yes & No \\
\hline Yes & No \\
\hline Yes & No \\
\hline & \\
\hline
\end{tabular}

activities such as movies, nightclubs, theater, etc.? Yes

Yes_ No No

Yes_ No

Yes_ No

Yes No

Yes No

Yes No

III. Please share your comments regarding the following. Mark $X$ next to those items that are true for you. Please answer as many as possible.

A. What are your feelings about being on publis assistance?

I accept being on public assistance (welfare)

I enjoy being on welfare

I don't like being on welfare

I appreciate being on welfare

I am not on welfare now and don't intend to be on welfare in the future

$\begin{array}{ll}\text { Yes___ No } & \text { No } \\ \text { Yes___ No } & \\ \text { Yes___ No__ } & \\ \text { Yes__ No }\end{array}$

B. How much has racial discrimination affected your resettling in America? Almost always sometimes never

C. How much pressure have you come up against in taking a job? Almost none little some much very much 
D. Do you know where to go for the following problems?

Medical and health problems

Race discrimination problems

Marriage problems

Welfare problems

Employment problems

Political problems

School problems

$\begin{array}{ll}\text { Yes } & \text { No } \\ \text { Yes } & \text { No } \\ \text { Yes } & \text { No } \\ \text { Yes } & \text { No } \\ \text { Yes } & \text { No } \\ \text { Yes_ } & \text { No } \\ \text { Yes } & \text { No }\end{array}$

E. What are the best things you have experienced with social service agencies (churches, welfare service, cultural center, etc.)?

The workers understand my problems and needs and help me.

The workers treat me with respect.

I don't have to wait too long for services.

They helped to find me a place to live, and

I'm happy with it.

They helped me to find a job, and I'm happy

with it.

They helped me with other things.

Yes

Yes

Yes

No

Please list

Yes No No

- No

Yes

Yes No No

F. What are the problems you have encountered with social service agencies? Language or communication problems

Cultural differences and misunderstandings Other problems

$\begin{array}{ll}\text { Yes } & \text { No } \\ \text { Yes } & \text { No } \\ \text { Yes } & \text { No }\end{array}$

Please list

G. How much success do you feel you have attained in your new life at this point?

Very much some little very little 
Chứg tôi thuộc trửong Dại.Học Portland State dang tố chửc một cuộc nghiên-

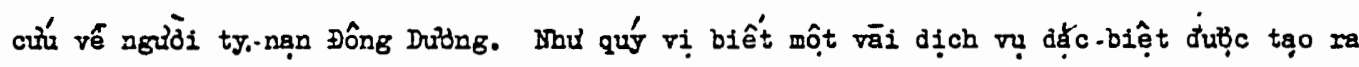

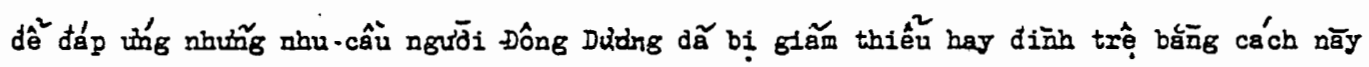

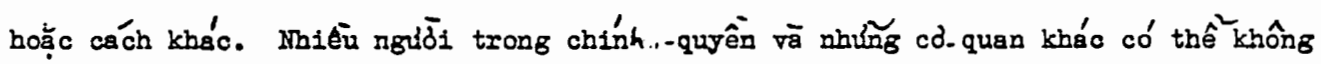

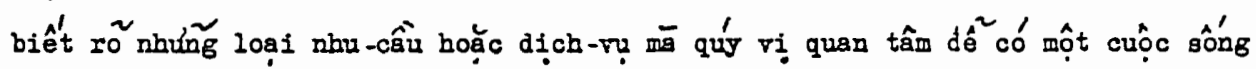

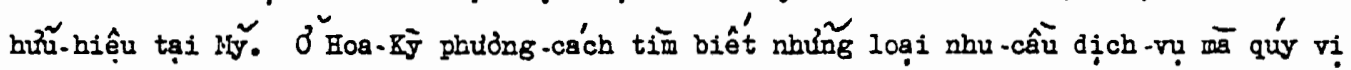

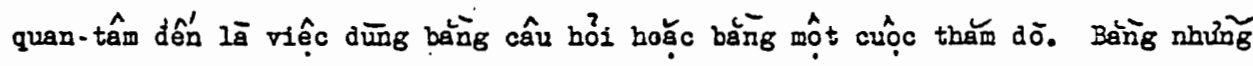

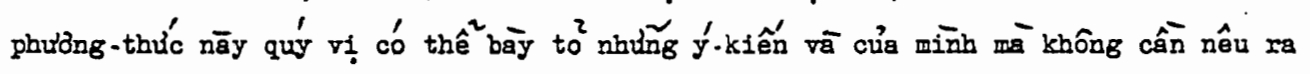

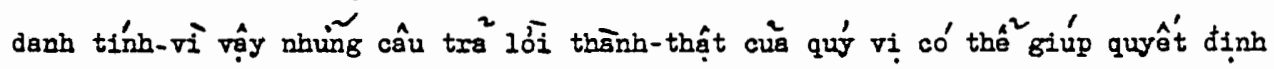

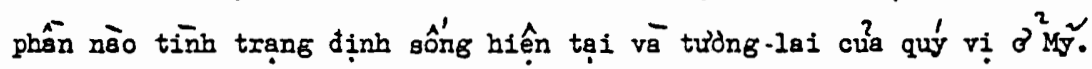

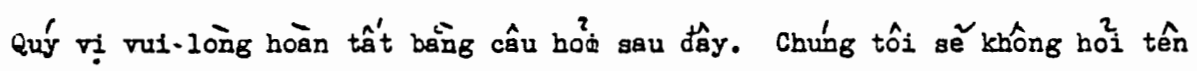

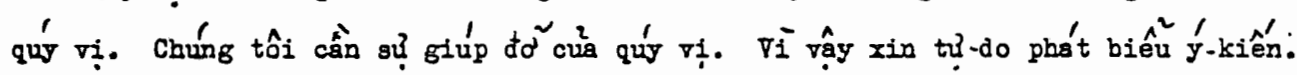

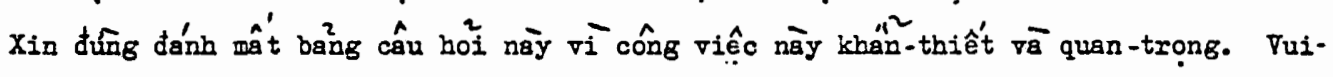

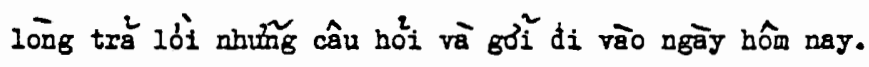

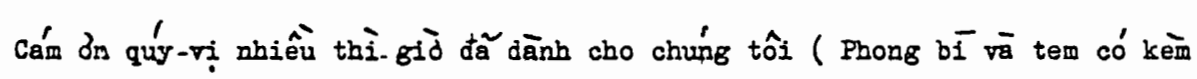
san dễ tiện riệc gỡ đên chúng tôi.) 


\section{TINB TRANG BAN THÂN}

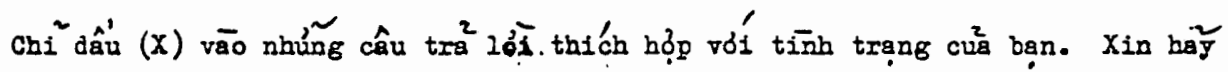

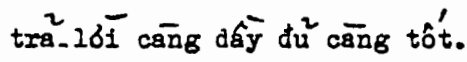

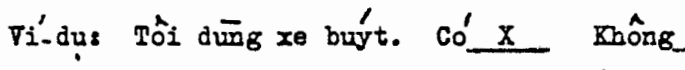

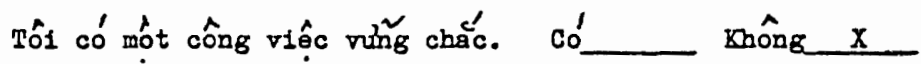

1. Quốc-tịch cua ban? Viêtnam Cam Bồt 150

2. Năm sinh? 19__. Nghếnghiệp (lức cōn $\partial^{2}$ Việtngm)

3. Tiñh trạg gia $d \hat{n} h$ ? $\boxplus \widehat{c} c$ thân có gia -dînh $L_{j}-d i$ Liv-than Gó bus

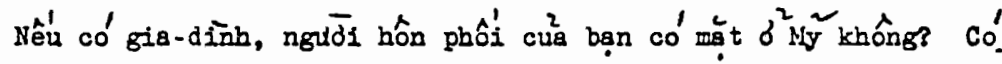
Không

4. Bạn thrộc vế phái nào? Nam $\mathrm{Nu}^{2}$

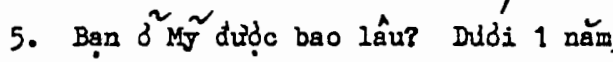
Tữ 1 dến 2 năm Tữ 3 đến 4 nถัm

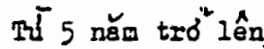

6. Bạn co' nói dược tiêng Anh không? Rất giớ Ká thông t tbạo Một chút i't Không nói dubọc

7. Ban có thế dọc Anb.ngữ không? Rất $\operatorname{gl}^{2} 0^{2}$ Khá Một ít Shông đọc được

8. Tón-gía cusa ban? Công-giáo Tôn gíá Krá́c Không tôn-gíó Phật-gíoo Tin-18inh

II. TINE TRANG SINE SÓNG HIÂM TAI

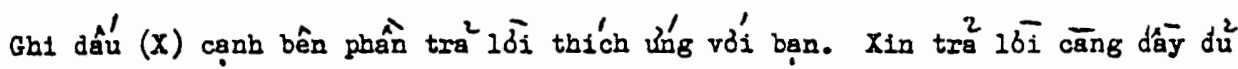

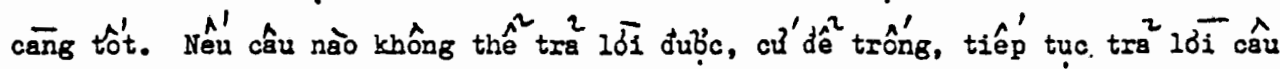
hơi ké tiêp.

A.

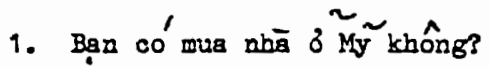

2. Bạ có xe hớ1 knông?

3. Bạ có bang lái xe không?

\begin{tabular}{|c|c|}
\hline $\mathrm{Co}^{\prime}$ & Khong \\
\hline Có & Không \\
\hline có_ & Khong \\
\hline
\end{tabular}


4. Bạn có việc läm kbông? Có Không

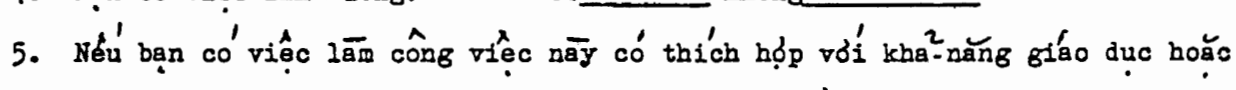
triñh dô chuseñ môn không. có Khong

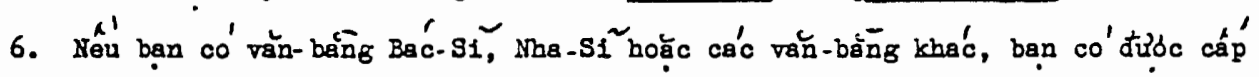
giấl hänh nghè tại H̃ không? có Thong

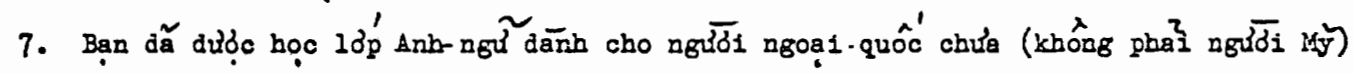
tó Chula

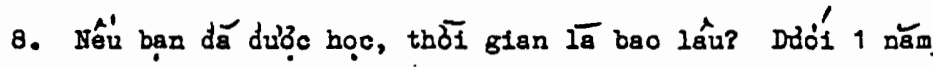
Tữ một dến 2 năm Trên 2 năm

9. Bạ co' những người ban M̛̃ không?

10. Bạn col tridong mục $\sigma^{2}$ nhä băng không?

11. Bạn có bao.hieem suć-khóe không?

12. Bạn co'bao hiêm re-bơi khóng?

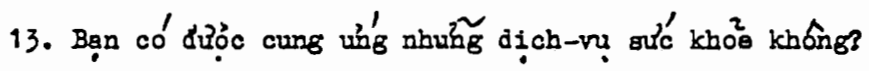

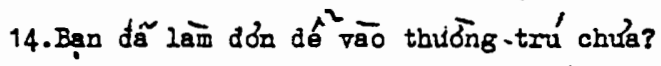
Chông có__L Không

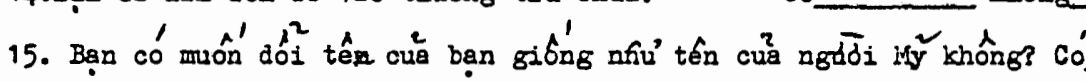
Khồng

B.

1. Bạn có sông với gia-diñ̂́ khóng?

Co Khong.

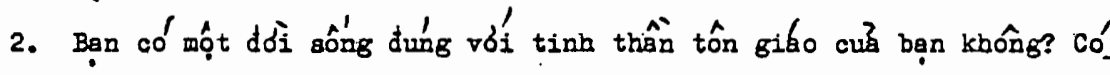
Không

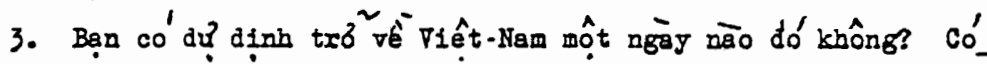
Không

4. Bạn có dược huẤn. lựẹn về ngtề-nghiêp không? có Khône

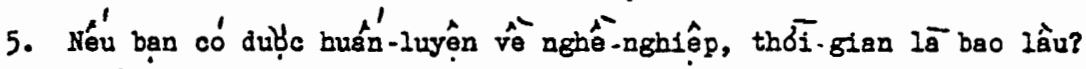
Drú̃í 1 năm Tर्थ 1 dên 2 nâm Hón 2 năm

6. Bạn co' thàm dự vaō những hật đợ̂ng vằn-hó không? Có Khống

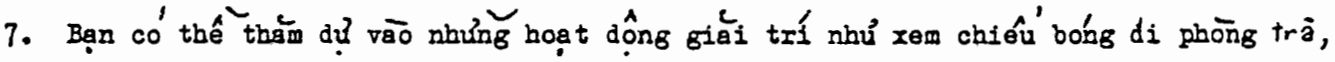
rạp hát?

$$
\text { Co }
$$
Bhong 
4.

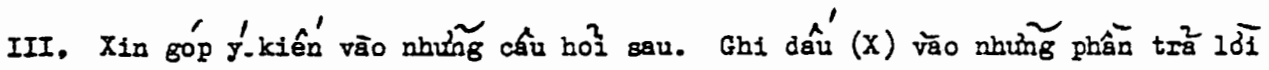

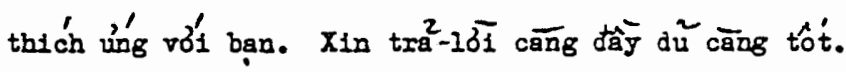

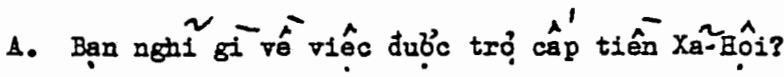

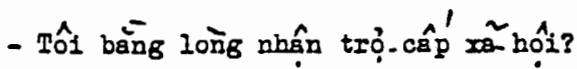

- Tố thích lañ tró. cấ $x \mathbf{a}^{2}-\mathrm{họi}$ ?

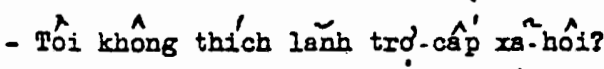

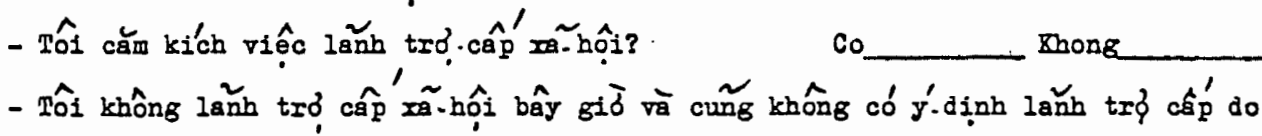

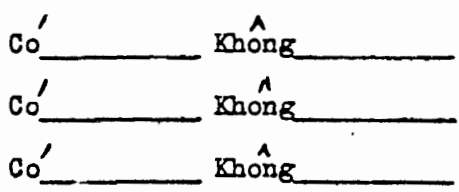
trong trỏng-lai? Có

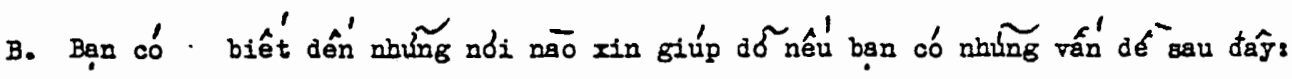

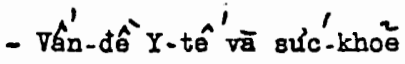

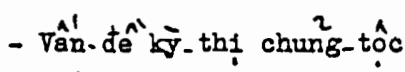

- Vấ - dé hôn nhâd

Biết

Biêt Khống

- Vân-dế trợ cấp zâ. bội

Biêt thông

- Vấ-dề tion viẹc là

- Vân-dè chián-tr!

- Vấn-dề giáa dục trud̄̄ng học

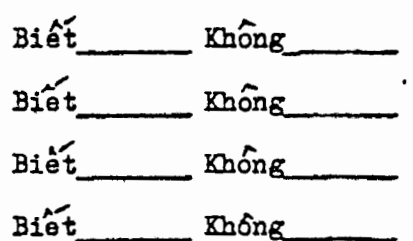

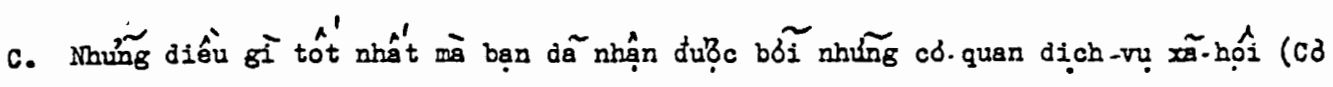

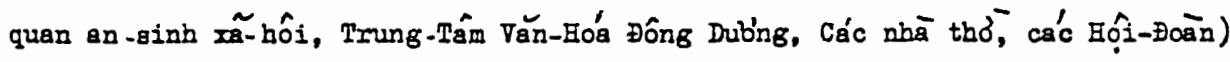

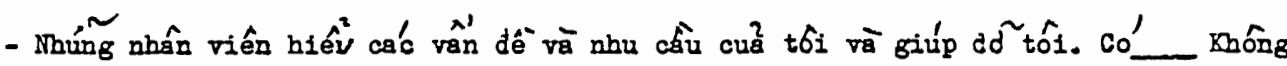

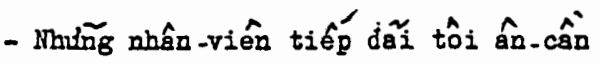
có Không

- Tồi không phài chõ đọi lâu khi xin giúp đठ̃

Co Bhong

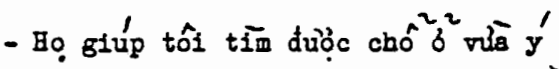
Co Khone

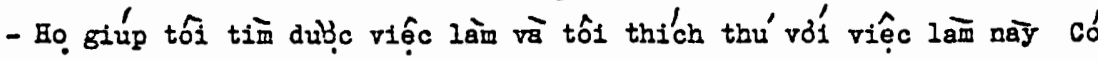
Bhong

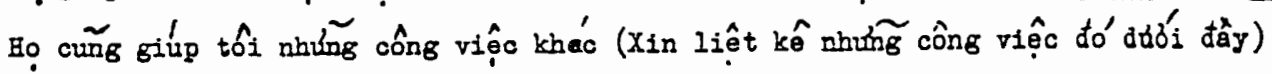




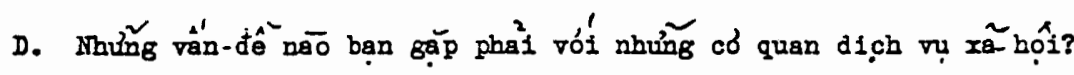

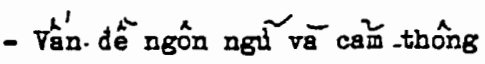

- Hiếu lâm vì ngôn ngữ khác biệt

có

Những vân đễ khác (xin Iiệt kê)

Có Cón Không

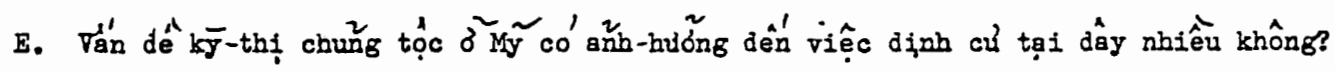
Luón Iuôn \#危 nhù luôn luồn Thinh thoang Khôngbso gió

F. Có boo nhiêu khó-kbăn bạn găp phài khi nhận một công việc? Hầu nhul không Ít Một vài Nhiéu Rśt nhiêu

G. Ban có thành cōng trong cuộc sóng mói vào giai dọan nèy không? thât nhiêù Nhién Môt $\overline{\nabla a i}$ It Rết ít 
CAMBODIAN MAJOR SURVEY

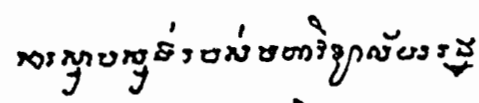

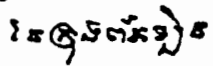

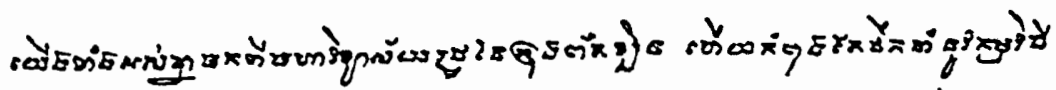

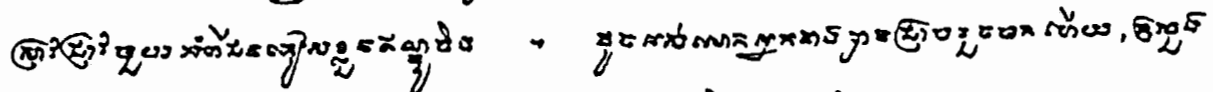

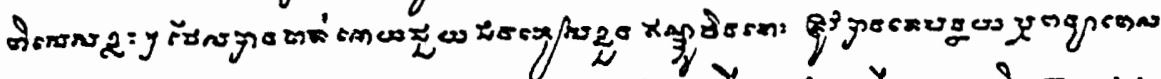

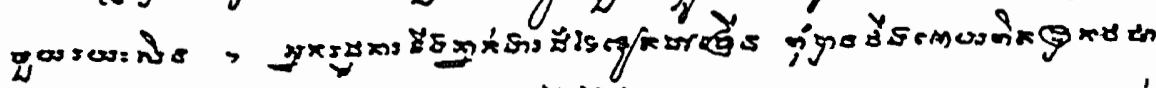

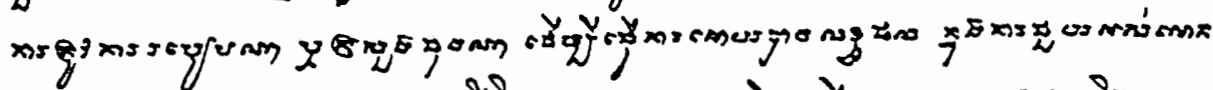

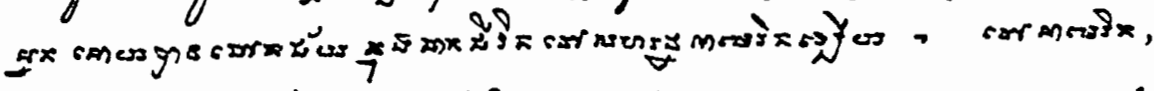

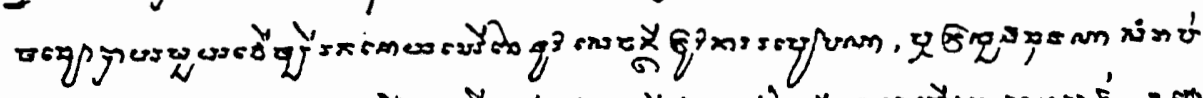

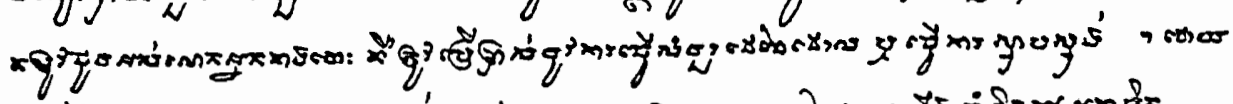

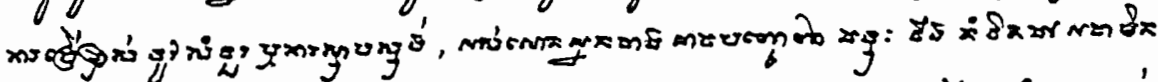

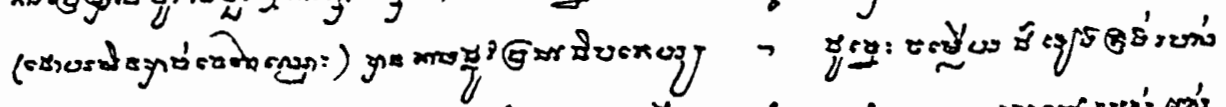

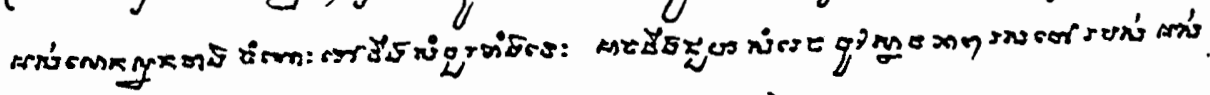

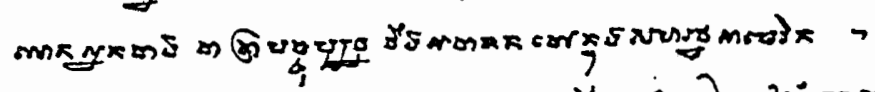

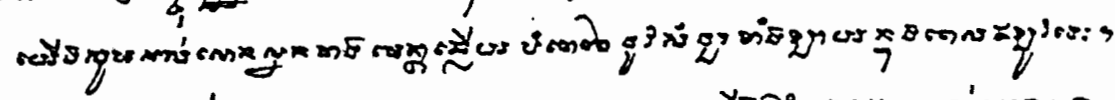
raxtspions 주 cos

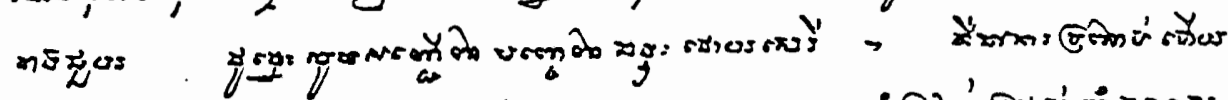

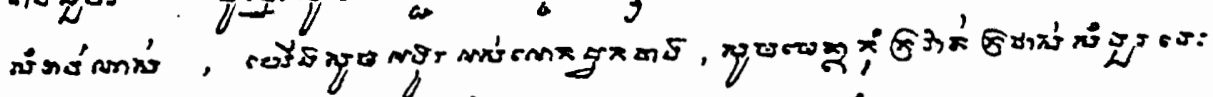

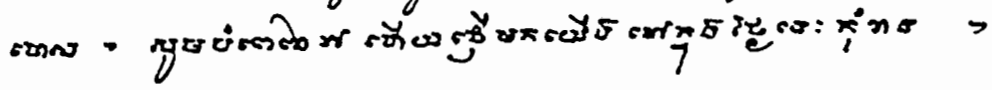

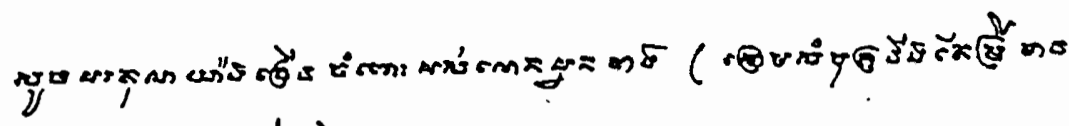

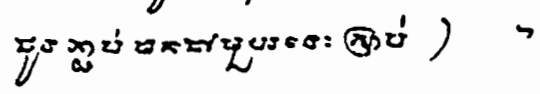


I nikgergatye

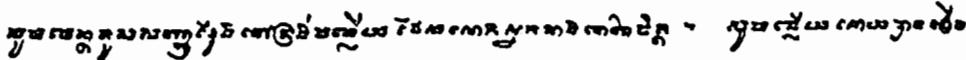

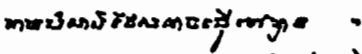

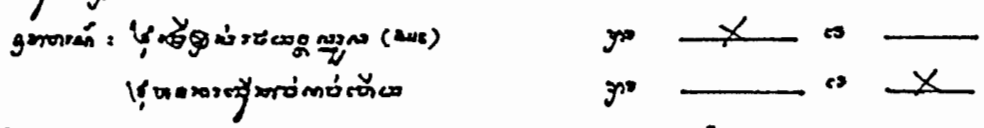

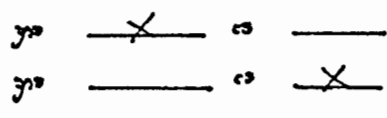

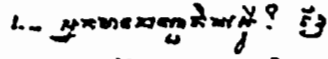

eqpares

$m$

2.- grextrumgen? of

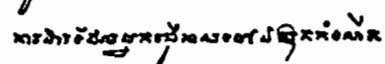

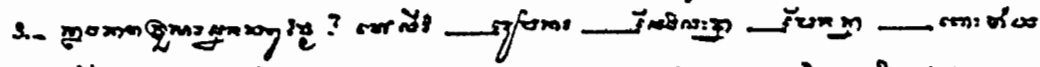

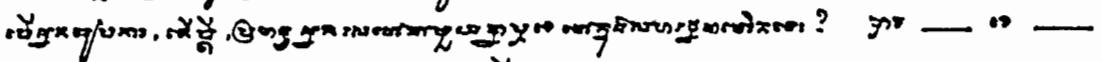

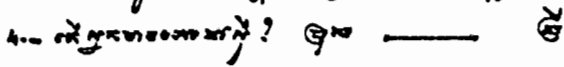

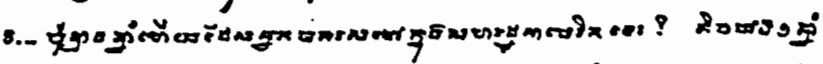
$9 \cos ^{2} \sin ^{\circ}$

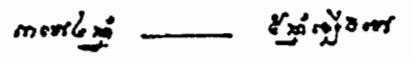

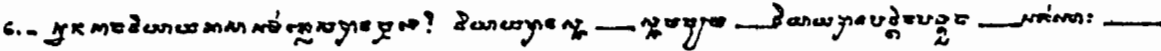

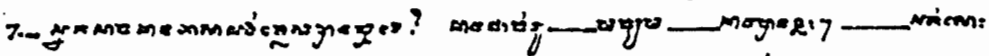

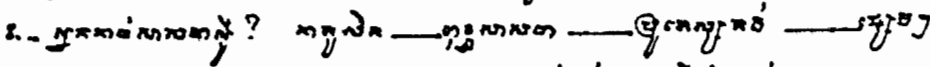

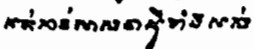

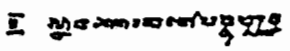

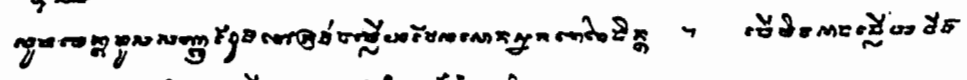

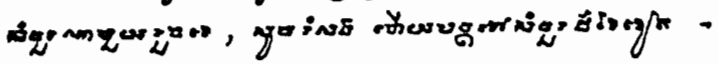

A. -

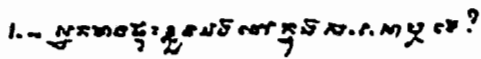

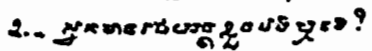

gis -

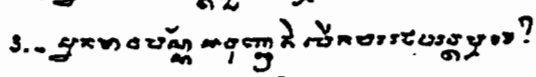

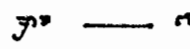

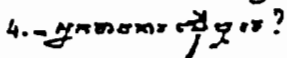

2ur

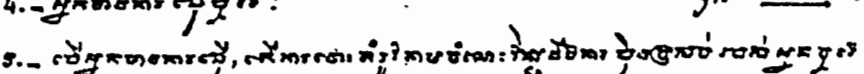

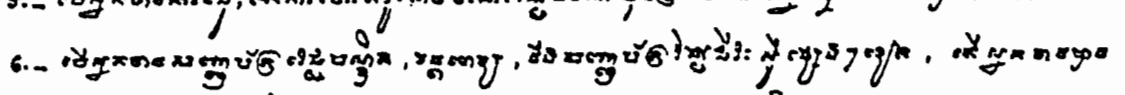

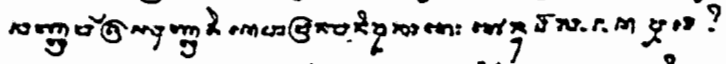

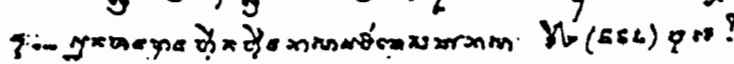

ᄁno $\rightarrow$

so os 


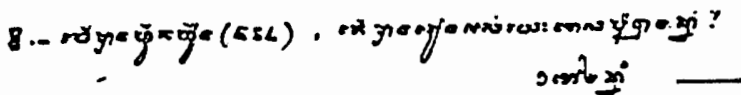
xexes Dxi -

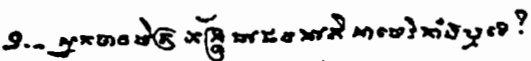

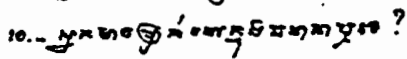

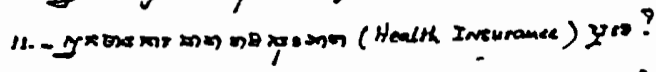

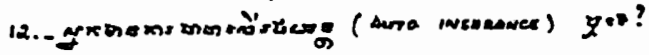
-ैै

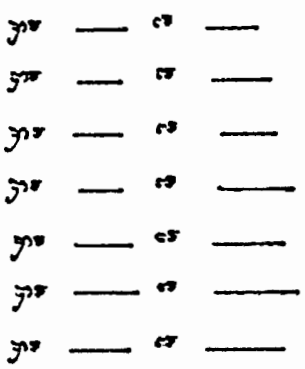

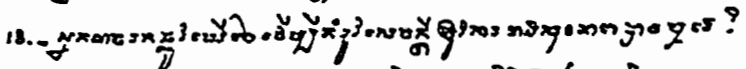

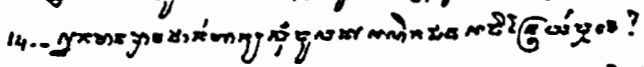

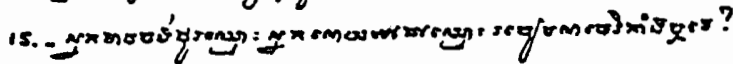
B.

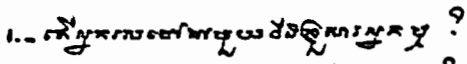

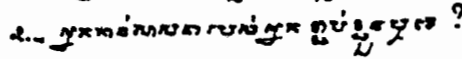

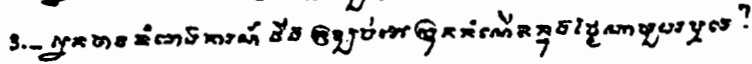
4.- भूत

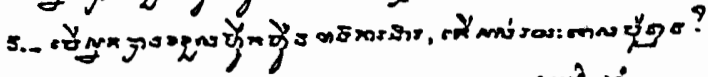

$$
2 \cos 0 \text { 20 }
$$

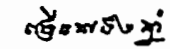

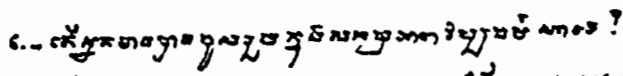

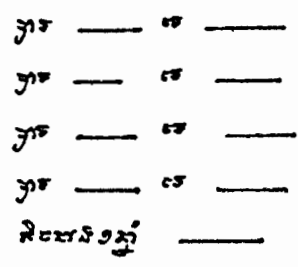

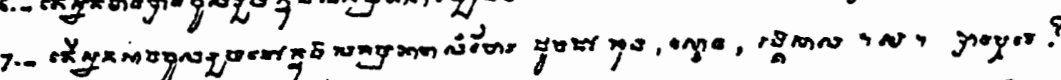

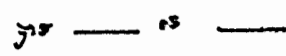

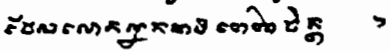

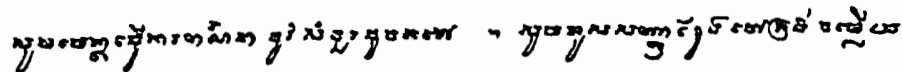

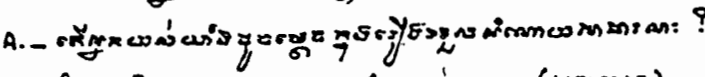

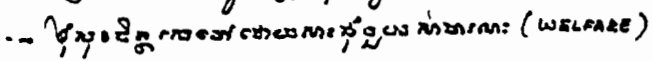

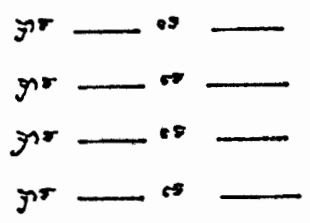

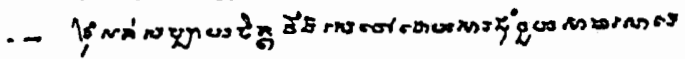

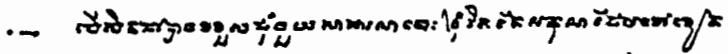

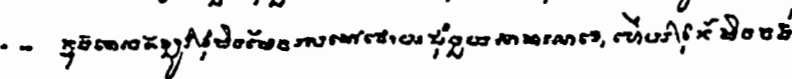
groxgerses: 


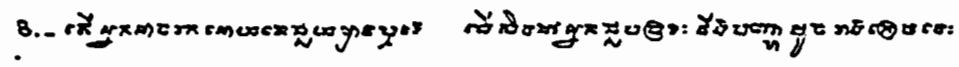

$$
\text { i- vorgas }
$$

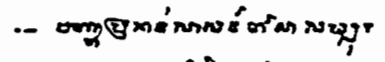

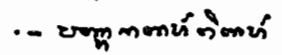

- - Dom

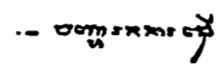

- oom oranger

- ormrenmege

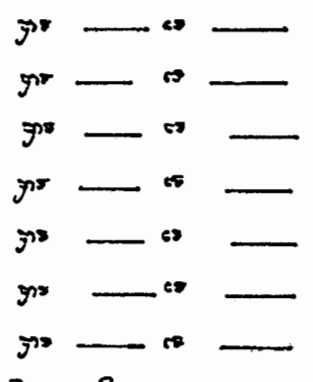

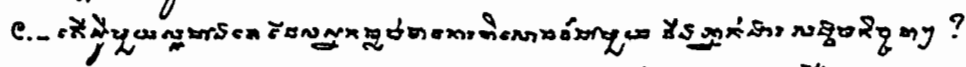

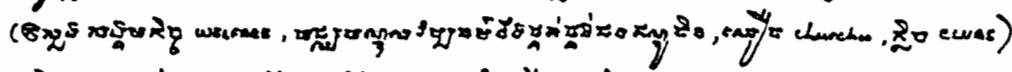

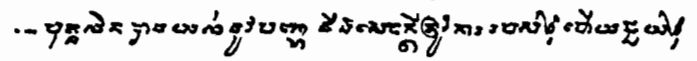

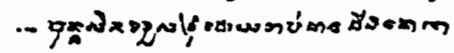

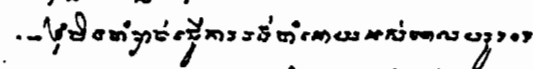

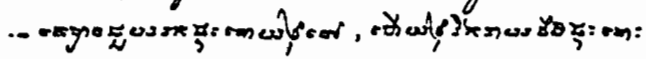

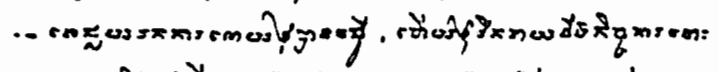

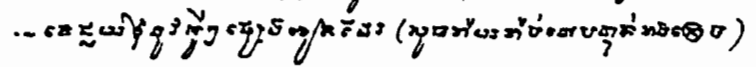

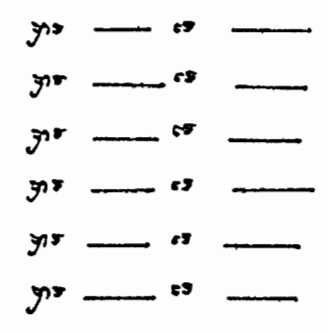

$$
\text { - - - - - - - - - - - }
$$

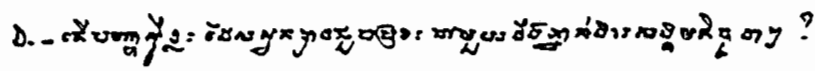

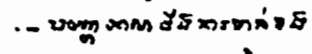

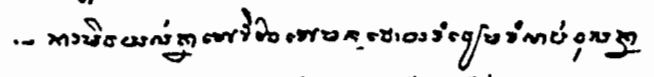

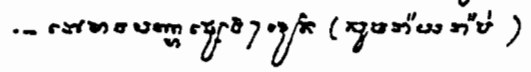

3

jo

ser

$2 \pi$

$$
-\longrightarrow-----
$$

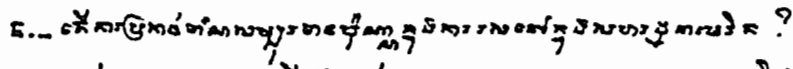

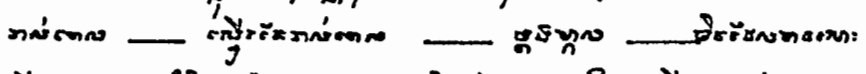

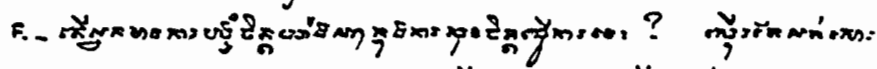

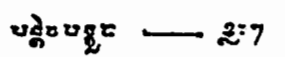
\&ैa ชैa and

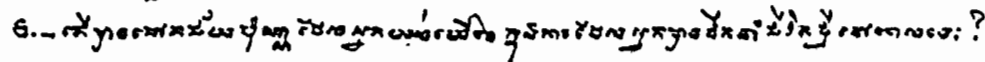
-

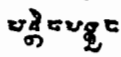
Recenounts 


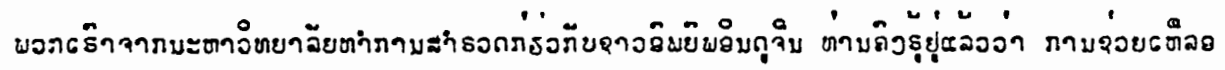

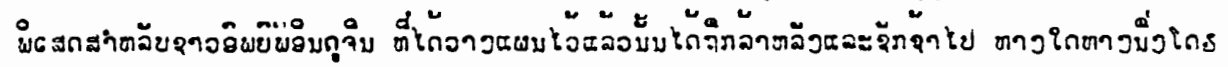

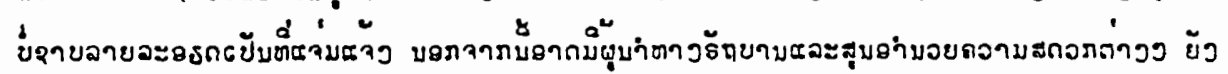

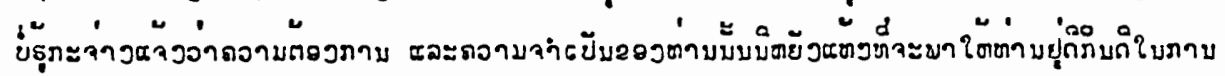

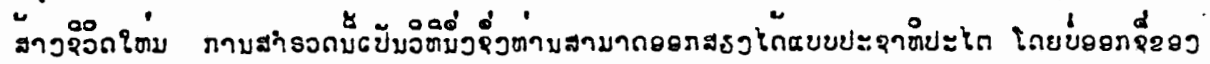

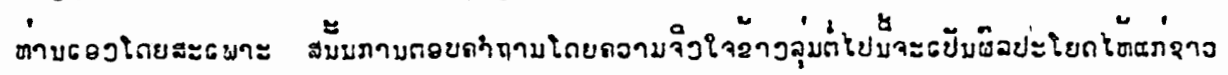

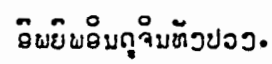

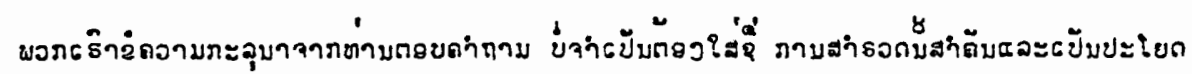

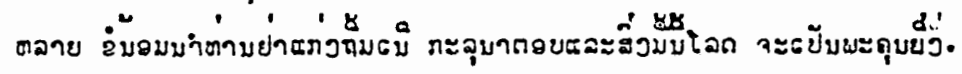

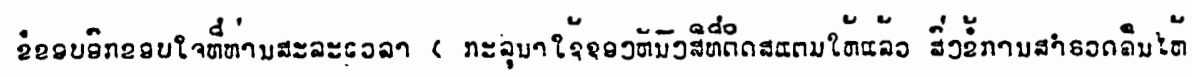

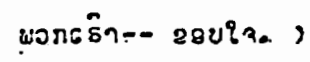

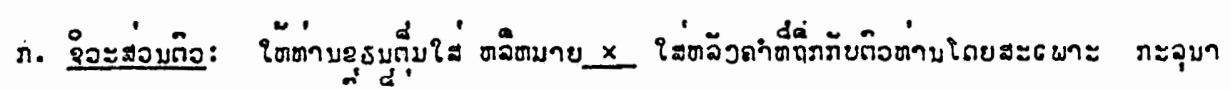

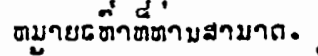

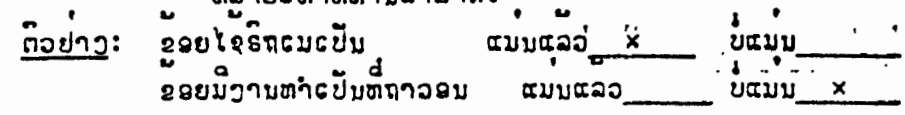

๑. ถ่ามลัมฉาลใล? จธกมาม__.

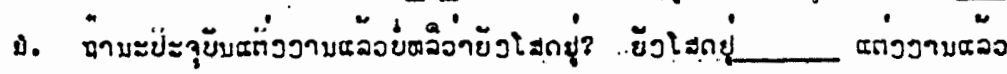

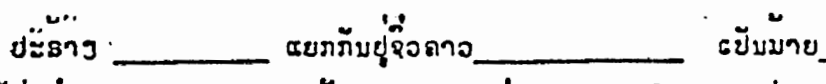

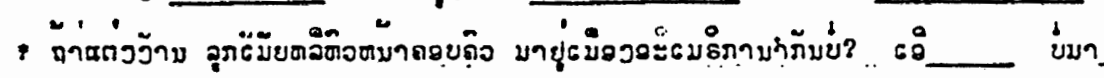

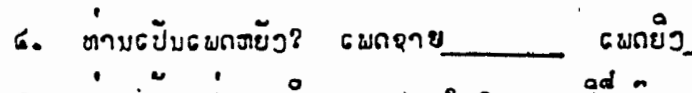

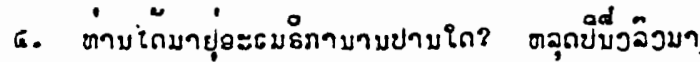

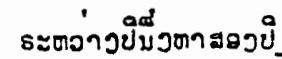

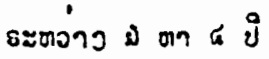

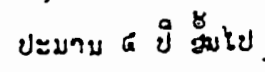

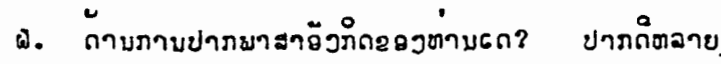
หร้ธลักบข้อย

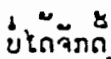

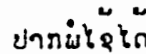




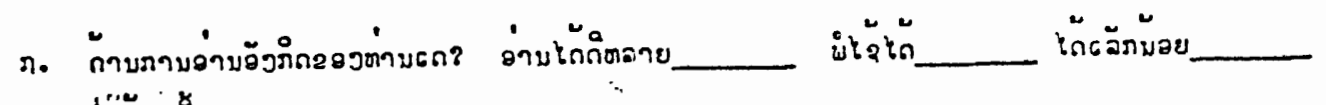

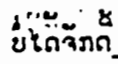

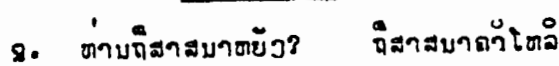

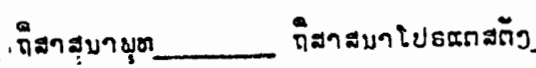
ทิสารมาอ็่ม ยม่สาสบบา

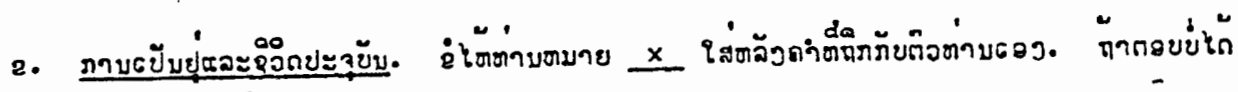

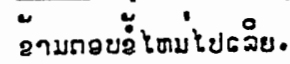
ก. . .

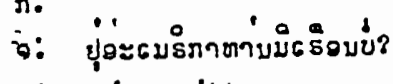
6. หามปริธยูป
ง. กา่บมิใขรับธี่ยใ?

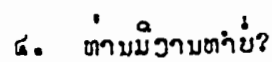

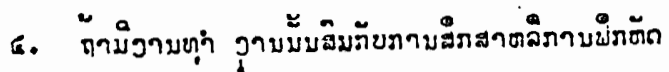 วามะ รวทามย?

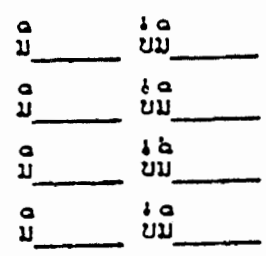

$$
6 \varepsilon_{1}, \text { ลี }
$$

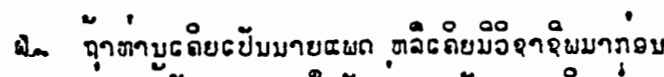

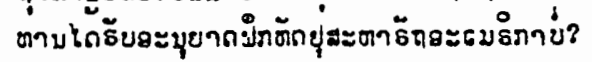

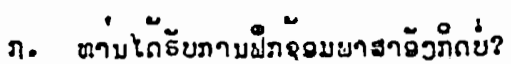

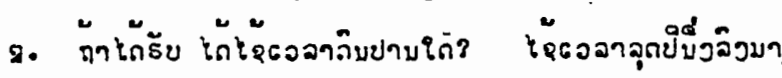

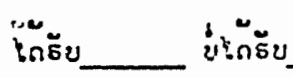

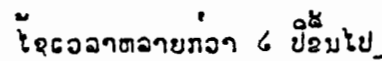

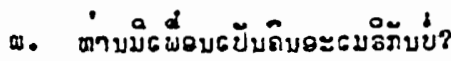

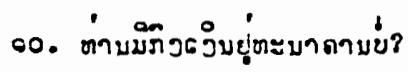

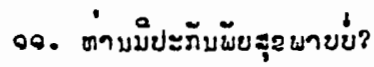

จ6. กาบมี่ะกับผัยธิธย์?

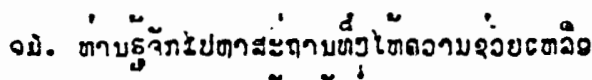
ตาวกาบถจาบธจับธขับย์?

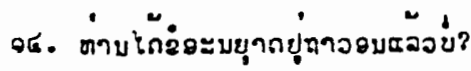

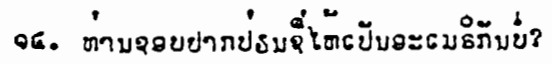
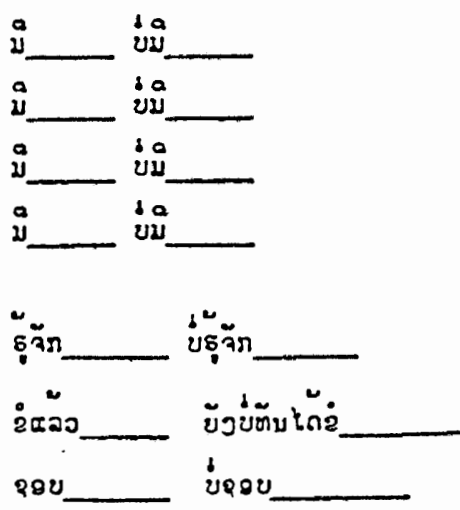
2.

2.

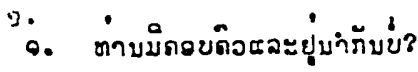

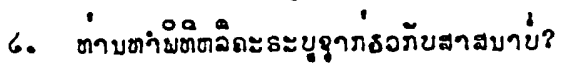

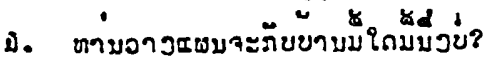

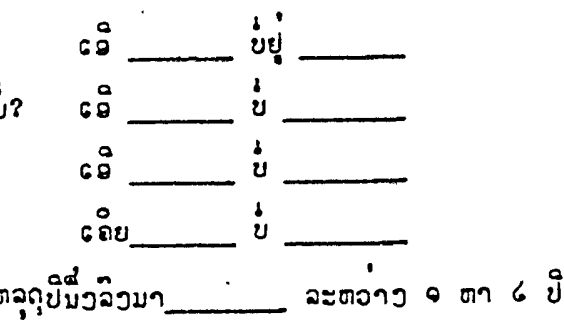

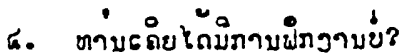

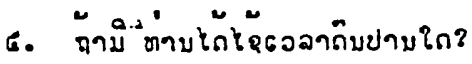
คุปูขอลวมา ละต่วง 0 ตา 6 ป

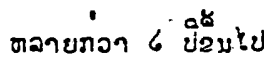

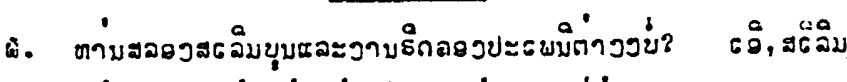

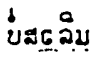

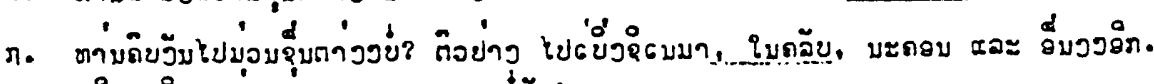
6ว, 6 ถัยไปม่วขยุ่ บมักไป

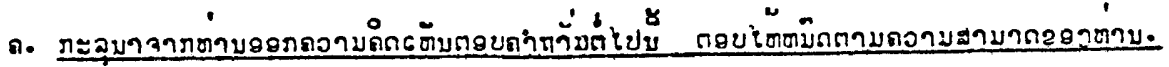

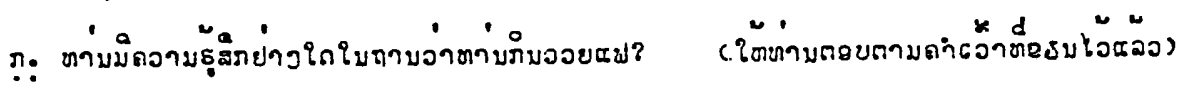

- 2รยยะมธัขกำวอยณป

ริข ขธ้น

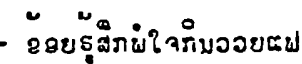

- 20

- 2อยบบักรัมววยธป

००० adve. ยว่อวย

\section{i?}

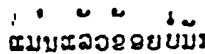
ช⿺辶? ชับก ขอบล์ ยมกิ

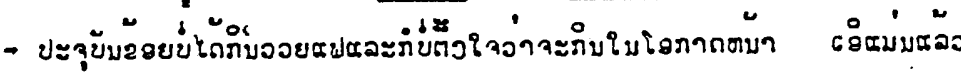
บับมัม

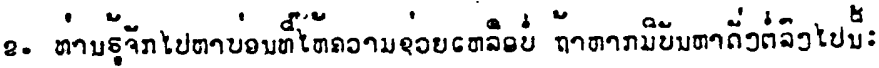

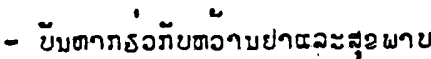

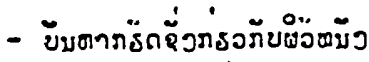

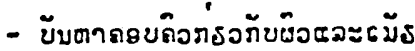

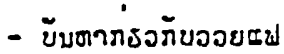

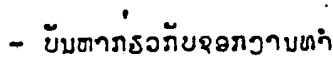

- บับชาก่รอรับงามธมีรง

- บัมตากรงกับโรวรรม

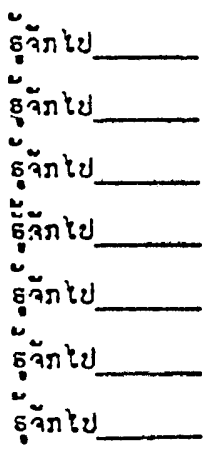

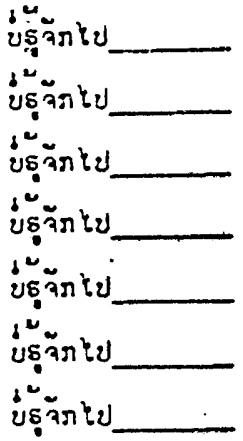


๔.

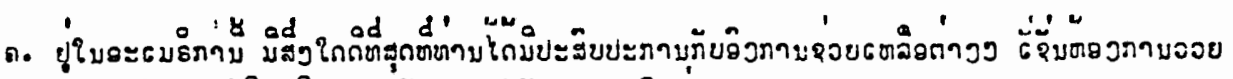

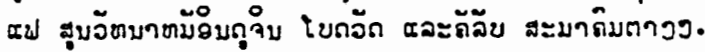

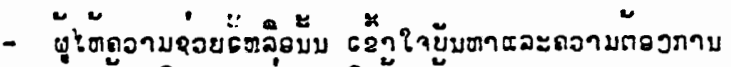

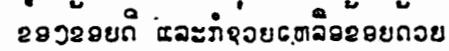

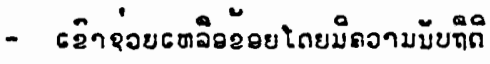

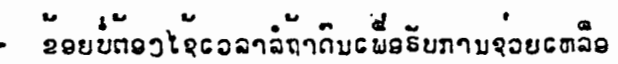

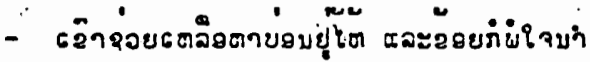

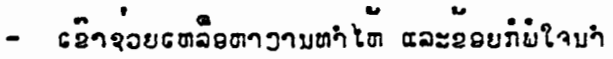

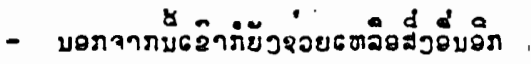

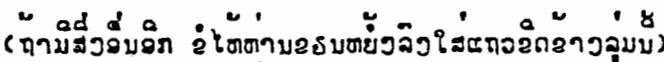

\begin{tabular}{|c|c|}
\hline ๘มบับัว & ชேม \\
\hline ๓บบบั & यับ \\
\hline 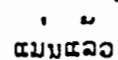 & ขับข \\
\hline ธ่มั & บณบข \\
\hline 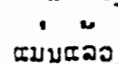 & uேxu \\
\hline 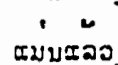 & ขฮมม \\
\hline
\end{tabular}

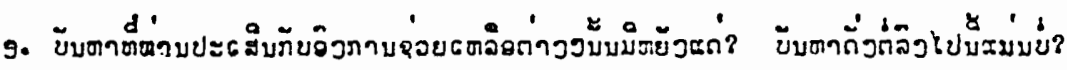

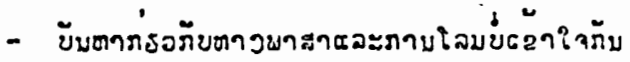

ณมบณวว ยัม่บ

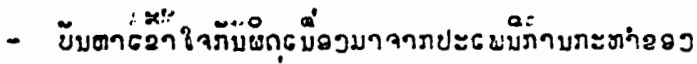

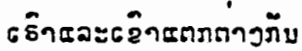

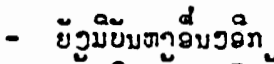
(ู)

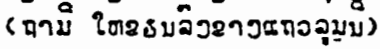

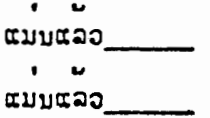

ยับบบ บับขบ

่ำำ่อั

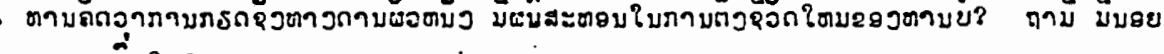
ตลายเที่าใด?

มี่ย่์ อับ

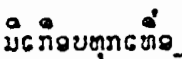

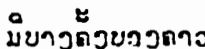

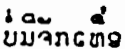

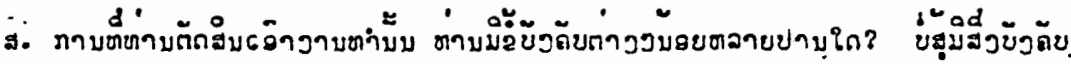

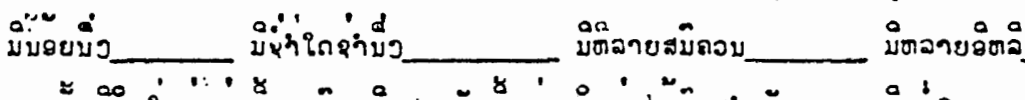

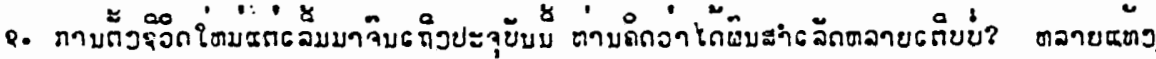
ตวายรีมถวาบ จำใดห่าบับ หักบอยกรอ

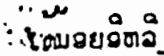


APPENDIX B

MAJOR PHASE TABULATED DATA 
TABLE XII

DISTRIBUTION OF SUCCESSFUL AND UNSUCCESSFUL REFUGEES WHO DO OR DO NOT OWN A HOME

Response

$$
\begin{array}{cccccc}
\text { Viet } & \multicolumn{2}{c}{\text { Successful }} & & \multicolumn{3}{c}{\text { Unsuccessful }} \\
\cline { 5 - 6 } N=28 & \frac{\text { Cam }}{N=5} & \frac{\text { Lao }}{N=10} & \frac{\text { Viet }}{N=23} & \frac{\text { Cam }}{N=5} & \frac{L a o}{N=7} \\
10(35.7 \%) & 1(20 \%) & 2(20 \%) & - & - & 1(14.2 \%) \\
18(64.2) & 4(80) & 8(80) & 22(95.6 \%) & 5(100 \%) 6(85.7) \\
- & - & - & 1(4.3) & - & -
\end{array}
$$

Yes

No

No response

\section{TABLE XIII}

DISTRIBUTION OF SUCCESSFUL AND UNSUCCESSFUL REFUGEES WHO DO OR DO NOT LIVE WITH THEIR FAMILIES

\begin{tabular}{|c|c|c|c|c|c|}
\hline \multicolumn{3}{|c|}{ Successful } & \multicolumn{3}{|c|}{ Unsuccessful } \\
\hline Vie & Cam & Lao & Viet & Cam & Lao \\
\hline $\mathrm{N}=28$ & $N=5$ & $\mathrm{~N}=10$ & $\mathrm{~N}=23$ & $\overline{\mathrm{N}=5}$ & $\overline{N=7}$ \\
\hline $21(75 \%$ & $4(80 \%)$ & $8(80 \%)$ & $11(47.8 \%)$ & $2(40 \%)$ & $7(100 \%)$ \\
\hline$(25$ & - & $2(20)$ & $12(52.2)$ & $1(20)$ & - \\
\hline - & $1(20)$ & - & - & $2(40)$ & - \\
\hline
\end{tabular}

Response

Yes
No
No response

Yes

No

No response

\section{$\underline{\text { Response }}$}

\section{TABLE XIV}

DISTRIBUTION OF SUCCESSFUL AND UNSUCCESSFUL WHO DO OR DO NOT OWN A CAR

$$
\frac{\text { Viet }}{N=28} \frac{\frac{\text { Successful }}{N=5}}{\frac{\text { Cam }}{N=10}} \quad \frac{\text { Viet }}{N=23} \frac{\text { Unsuccessful }}{\frac{\text { Cam }}{N=5}} \frac{\text { Lao }}{N=7}
$$$$
27(96.4 \%) \quad 5(100 \%) \quad 7(70 \%) \quad 11(47.8 \%) 2(40 \%) \quad 5(71.4 \%)
$$$$
1(3.5) \quad-\quad 3(30) \quad 12(52.1) \quad 3(60) \quad 2(28.5)
$$ 
TABLE XV

DISTRIBUTION OF SUCCESSFUL AND UNSUCCESSFUL REFUGEES WHO DO OR DO NOT HAVE A DRIVER'S LICENSE

Response

Yes

No

No response

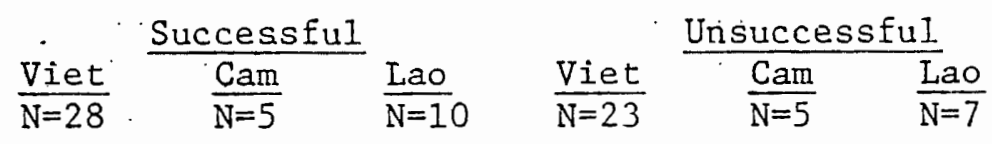

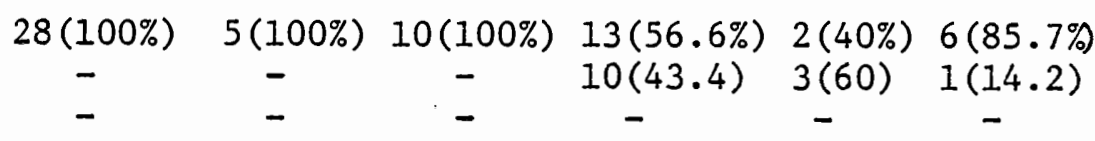

TABLE XVI

DISTRIBUTION OF SUCCESSFUL AND UNSUCCESSFUL REFUGEES

WHO DO OR DO NOT HAVE A JOB

Response

SuccessfuI

Unsuccessful

$\frac{V i e t}{N=28} \quad \frac{\text { Cam }}{N=5} \quad \frac{\text { Lao }}{N=10} \quad \frac{\text { Viet }}{N=23} \quad \frac{\text { Cam }}{N=5} \quad \frac{\text { Lao }}{N=7}$

Yes

No

$\begin{array}{llllll}24(85.6 \%) & 3(60 \%) & 8(80 \%) & 11(47.8 \%) & 1(20 \%) & 5(71.4 \%)\end{array}$

No response

$3(10.7)$

$1(3.5)$

$2(40) \quad 2(20) \quad 11(47.8) \quad 4(80) \quad 2(28.5)$

\section{TABLE XVII}

DISTRIBUTION OF SUCCESSFUL AND UNSUCCESSFUL REFUGEES WHO DO OR DO NOT HAVE A JOB SUITING THEIR EDUCATION AND SKILLS

$\underline{\text { Response }}$

Yes
No
No response
Súcessful

$$
\frac{\text { Viet }}{\mathrm{N}=28} \quad \frac{\mathrm{Cam}}{\mathrm{N}=5} \quad \frac{\mathrm{LaO}}{\mathrm{N}=10}
$$

$9(32.1 \%) \quad 1(20 \%) \quad 6(60 \%)$

$15(53.5) \quad 3(60)$

$4(14.2) \quad 1(20)$
$4(40)$

$13(56.6 \%) \quad 1(20 \%)$

$1(4.3)$

$9(39.1)$
Unsuccessful

$$
\frac{V i e t}{N=23} \quad \frac{\text { Cam }}{N=5} \quad \frac{L a o}{N=7}
$$

$$
\begin{array}{ll}
3(60) & 4(57.1 \% \\
1(20) & 3(42.8)
\end{array}
$$


DISTRIBUTION OF SUCCESSFUL AND UNSUCCESSFUL REFUGEES WHO DO OR DO NOT HAVE RECERTIFIED DEGREES

$\underline{\text { Response }}$

$$
\frac{\text { Viet }}{N=28} \quad \frac{\text { Successful }}{\frac{\text { Cam }}{N=5}} \quad \frac{\text { Lao }}{N=10} \quad \frac{\text { Viet }}{N=23} \quad \frac{\text { Unsuccessful }}{N=5} \quad \frac{\text { Lao }}{N=7}
$$

$\begin{array}{llllllc}\text { Yes } & 5(17.8 \%) & 2(40 \%) & 3(30 \%) & 4(17.3 \%) & 3(60 \%) & - \\ \text { No } & 10(35.7) & 1(20) & 6(60) & 6(26 .) & - & 7(100 \%) \\ \text { No response } & 13(46.4) & 2(40) & 1(10) & 13(56.5) & 2(40) & -\end{array}$

TABLE XIX

DISTRIBUTION OF SUCCESSFUL AND UNSUCCESSFUL REFUGEES

WHO HAVE OR HAVE NOT HAD JOB TRAINING

Response

$$
\begin{aligned}
& \frac{\text { Viet }}{\mathrm{N}=28} \quad \frac{\text { Successful }}{\mathrm{N}=5} \quad \frac{\text { Lao }}{\mathrm{N}=10} \quad \frac{\text { Viet }}{\mathrm{N}=23} \quad \frac{\text { Unsuccessful }}{\frac{\text { Cam }}{\mathrm{N}=5}} \quad \frac{\text { Lao }}{\mathrm{N}=7} \\
& \begin{array}{lllllll}
\text { Yes } & 12(42.9 \%) & 2(40 \%) & 5(50 \%) & 16(69.6 \%) & - & 2(28.6 \%) \\
\text { No } & 13(46.4) & 2(40) & 4(40) & 6(26.1) & 1(20 \%) & 5(71.4) \\
\text { No response } & 3(10.7) & 1(20) & 1(10) & 1(4.3) & 4(80) & -
\end{array}
\end{aligned}
$$

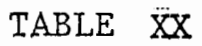

DISTRIBUTION OF SUCCESSFUL AND UNSUCCESSFUL REFUGEES

WHO HAVE OR HAVE NOT HAD ESL TRAINING

Response

$$
\frac{\text { Viet }}{\mathrm{N}=28} \quad \frac{\text { Successful }}{\frac{\text { Cam }}{\mathrm{N}=5}} \quad \frac{\text { Lao }}{\mathrm{N}=10} \quad \frac{\text { Viet }}{\mathrm{N}=23} \frac{\text { Unsuccessful }}{\frac{\text { Cam }}{\mathrm{N}=5}} \frac{\text { Lao }}{\mathrm{N}=7}
$$

Yes

$16(57.1 \%) \quad 3(60 \%) \quad 9(90 \%) \quad 12(52.1 \%) \quad 4(80 \%) \cdot 4(57.1 \%$

No

$9 .(32.1)$

$9(39.1)$

1(20)

$3(42.8)$

No response

$3(10.7)$

$2(8.6)$ 
TABLE XXI

DISTRIBUTION OF SUCCESSFUL AND UNSUCCESSFUL REFUGEES WHO DO OR DO NOT HAVE AMERICAN FRIENDS

Response

$$
\begin{aligned}
& \frac{\text { Viet }}{\mathrm{N}=28} \cdot \frac{\text { Successful }}{\mathrm{N}=5} \frac{\mathrm{LaO}}{\mathrm{N}=10} \quad \frac{\text { Viet }}{\mathrm{N}=23} \frac{\text { Unsuccessful }}{\mathrm{N}=5} \frac{\text { LaO }}{\mathrm{N}=7} \\
& 26(92.8 \%) \quad 4(80 \%) \quad 9(90 \%) \quad 6(26 \%) \quad 1(20 \%), 2(28.5 \%)
\end{aligned}
$$

Yes

No

No response

$\begin{array}{llllll}2(7.2) & 1(20) & 1(10) & 16(69.5) & 2(40) & 5(71.4)\end{array}$

TABLE XXII

DISTRIBUTION OF SUCCESSFUL AND UNSUCCESSFUL REFUGEES WHO DO OR DO NOT PRACTICE THEIR RELIGION

Response

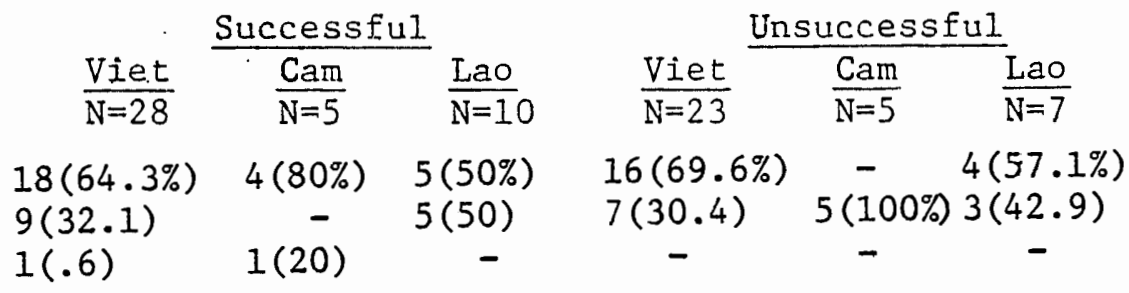

Yes

No

No response

TABLE XXIII

DISTRIBUTION OF SUCCESSFUL AND UNSUCCESSFUL REFUGEES WHO DO OR DO NOT PARTICIPATE IN CULTURAL ACTIVITIES

Response

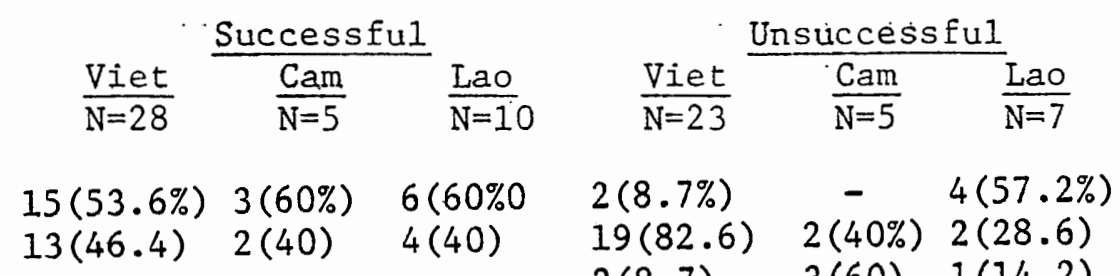

Yes

No

No response

- $2(8.7) \quad 3(60) \quad 1(14.2)$


DISTRIBUTION OF SUCCESSFUL AND UNSUCCESSFUL REFUGEES WHO DO OR DO NOT HAVE BANK ACCOUNTS

Response

Yes

No

No response

$$
\begin{aligned}
& \frac{\text { Viet }}{\mathrm{N}=28} \quad \frac{\text { Successfu1 }}{\frac{\text { Cam }}{\mathrm{N}=5}} \quad \frac{\text { Lao }}{\mathrm{N}=10} \quad \frac{\text { Viet }}{\mathrm{N}=23} \quad \frac{\text { Unisuccessful }}{\mathrm{N}=5} \quad \frac{\mathrm{CaO}}{\mathrm{N}=7} \\
& 24(85.7 \%) 2(40 \%) \quad 8(80 \%) \quad 10(43.4 \%)-2(28.5 \%) \\
& \begin{array}{llllll}
4(14.2) & 3(60) & 2(20) & 12(52.1) & 3(60 \%) & 5(71.4)
\end{array} \\
& \text { - - } \quad-1(4.3) \quad 2(40)
\end{aligned}
$$

TABLE XXV

DISTRIBUTION OF SUCCESSFUL AND UNSUCCESSFUL REFUGEES

WHO DO OR DO NOT HAVE HEALTH INSURANCE

Response

\begin{tabular}{lcccccc} 
& \multicolumn{3}{l}{ Successful } & & \multicolumn{3}{l}{ Unsuccessfu1 } \\
$\frac{\text { Viet }}{\mathrm{N}=28}$ & $\frac{\text { Cam }}{\mathrm{N}=5}$ & $\frac{\text { Lao }}{\mathrm{N}=10}$ & $\frac{\text { Viet }}{\mathrm{N}=23}$ & $\frac{\text { Cam }}{\mathrm{N}=5}$ & $\frac{\text { Lao }}{\mathrm{N}=7}$ \\
$22(78.5 \%)$ & $4(80 \%)$ & $8(80 \%)$ & $5(21.7 \%)$ & $1(20)$ & - \\
$5(17.8)$ & $1(20)$ & $2(20)$ & $19(82.6)$ & $3(60)$ & $7(100 \%)$ \\
$1(3.5)$ & - & - & - & $1(20)$ & -
\end{tabular}

TABLE XXVI

DISTRIBUTION OF SUCCESSFUL AND UNSUCCESSFUL REFUGEES WHO DO OR DO NOT HAVE AUTO INSURANCE

Response

$$
\frac{\text { Viet }}{N=28} \frac{\frac{\text { Successful }}{\mathrm{N}=5}}{\frac{\text { Lam }}{\mathrm{N}=10}} \quad \frac{\text { Viet }}{\mathrm{N}=23} \frac{\frac{\text { Unsuccessfu1 }}{\mathrm{N}=5}}{\frac{\text { Cam }}{\mathrm{N}=7}}
$$

$\begin{array}{llcclll}\text { Yes } & 23(82.1 \%) & 5(100 \%) & 10(100 \%) & 10(43.4 \%) & 1(20 \%) & 5(71.4 \%) \\ \text { No } & 4(14.2) & - & - & 11(47.8) & 3(60) & 2(28.5) \\ \text { No response } & 1(3.5) & - & - & 2(8.6) & 2(20) & -\end{array}$


DISTRIBUTION OF SUCCESSFUL AND UNSUCCESSFUL REFUGEES WHO DO OR DO NOT HAVE ACCESS TO MEDICAL SERVICES

Response

$$
\begin{aligned}
& \frac{\text { Viet }}{\mathrm{N}=28} \quad \frac{\text { Successful }}{\mathrm{N}=5} \quad \frac{\text { Lao }}{\mathrm{N}=10} \quad \frac{\text { Viet }}{\mathrm{N}=23} \quad \frac{\text { Unsuccessful }}{\mathrm{N}=5} \quad \frac{\text { Lao }}{\mathrm{N}=7}
\end{aligned}
$$

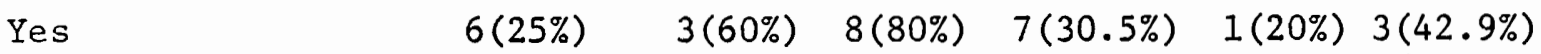

$$
\begin{aligned}
& \begin{array}{lllllll}
\text { No response } & 4(10.7) & - & - & 5(21.7) & 2(40)
\end{array}
\end{aligned}
$$$$
\begin{array}{lllllll}
\text { No } & 18(64.3) & 2(40) & 2(20) & 11(47.8) & 2(40) & 4(57.1)
\end{array}
$$

\section{TABLE XXVIII}

DISTRIBUTION OF SUCCESSFUL AND UNSUCCESSFUL REFUGEES WHO DO OR DO NOT PARTICIPATE IN RECREATION ACTIVITIES

Response

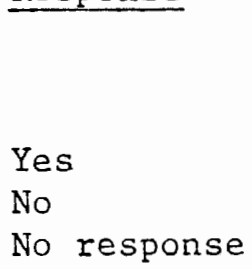

$$
\frac{\text { Vie.t }}{\mathrm{N}=28} \stackrel{\frac{\text { Successful }}{\mathrm{Cam}}}{\frac{\mathrm{LaO}}{\mathrm{N}=5}}
$$

$\begin{array}{lll}16(57.1 \%) & - & 6(60 \%) \\ 8(32.2) & 4(80 \%) & 4(40) \\ 4(10.7) & 1(20) & -\end{array}$

\section{TABLE $\quad \mathrm{XXIX}$}

DISTRIBUTION OF SUCCESSFUL AND UNSUCCESSFUL REFUGEES WHO HAVE OR HAVE NOT APPLIED FOR PERMANENT RESIDENCY

Response

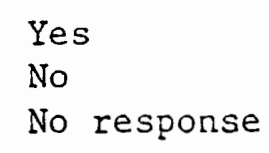

$$
\frac{\text { Viet }}{\mathrm{N}=28} \frac{\frac{\text { Successful }}{\mathrm{N}=5}}{\frac{\mathrm{Cam}}{\mathrm{N}=10}} \quad \frac{\text { Viet }}{\mathrm{N}=23} \quad \frac{\text { Unsuccessful }}{\frac{\text { Cam }}{\mathrm{N}=5}} \quad \frac{\mathrm{LaO}}{\mathrm{N}=7}
$$$$
\begin{array}{lccccc}
16(57.1 \%) & 2(40 \%) & 3(30 \%) & 7(30.4 \%) & - & 1(14.2 \%) \\
8(32.2) & 3(60) & 7(70) & 16(47.8) & 2(40 \%) & 6(85.8 \%) \\
4(10.7) & - & - & 4(17.4) & 3(60) & -
\end{array}
$$ 
TABLE XXX

DISTRIBUTION OF SUCCESSFUL AND UNSUCCESSFUL REFUGEES

WHO ARE OR ARE NOT WILLING TO AMERICANIZE THEIR NAMES

Response

Successful

Unsuccessful

$$
\frac{\text { Viet }}{N=28} \quad \frac{\text { Cam }}{N=5} \quad \frac{\text { Lao }}{N=10} \quad \frac{\text { Viet }}{N=23} \quad \frac{\text { Cam }}{N=5} \quad \frac{\text { Lao }}{N=7}
$$

$\begin{array}{lllllll}\text { Yes } & 6(25 \%) & 2(40 \%) & 6(60 \%) & 3(10.7 \%) & - & 3(42.9 \%) \\ \text { No } & 20(66.8) & 3(60) & 4(40) & 18(80.6) & 2(40 \%) & 3(42.9) \\ \text { No response } & 2(8.2) & - & - & 2(8.7) & 3(60) & 1(14.2)\end{array}$

The following tables represent the tabulated data from the "Attitudes and Perceptions" section of the major phase survey. 
TABLE XXXI

DISTRIBUTION OF SUCCESSFUL AND UNSUCCESSFUL REFUGEES WHO DO OR DO NOT KNOW WHERE TO GO FOR MEDICAL/HEALTH PROBLEMS

Response

$$
\frac{\text { Viet }}{\mathrm{N}=28} \cdot \frac{\text { Successful }}{\mathrm{N}=5} \quad \frac{\mathrm{CaO}}{\mathrm{N}=10} \quad \frac{\text { Viet }}{\mathrm{N}=23} \quad \frac{\text { Unisuccessful }}{\mathrm{N}=5} \frac{\mathrm{LaO}}{\mathrm{N}=7}
$$

$\begin{array}{llllllc}\text { Yes. } & 20(71 \%) & 4(80 \%) & 7(70 \%) & 6(26 \%) & 2(40 \%) & 3(43 \%) \\ \text { No } & 7(25) & - & 3(30) & 16(70) & 2(40) & 4(57) \\ \text { No response } & 1(4) & 1(20) & - & 1(4) & 1(20) & -\end{array}$

TABLE XXXII

DISTRIBUTION OF SUCCESSFUL AND UNSUCCESSFUL REFUGEES WHO DO OR DO NOT KNOW WHERE TO GO FOR RACE DISCRIMINATION PROBLEMS

Response

$$
\frac{\text { Viet }}{\mathrm{N}=28} \frac{\frac{\text { Successfu1 }}{\mathrm{N}=5}}{\frac{\text { Cam }}{\mathrm{N}=10}} \quad \frac{\text { Viet }}{\mathrm{N}=23} \quad \frac{\text { Unsuccessful }}{\mathrm{N}=5} \quad \frac{\mathrm{LaO}}{\mathrm{N}=7}
$$

$\begin{array}{lcccccc}\text { Yes } & 7(25 \%) & 2(40 \%) & 3(30 \%) & 3(13 \%) & - & 1(14 \%) \\ \text { No } & 21(75) & 3(60) & 7(70) & 3(13) & 3(60 \%) & 6(86) \\ \text { No response } & - & - & - & 17(74) & 2(40) & -\end{array}$

\section{TABLE XXXIII}

DISTRIBUTION OF SUCESSFUL AND UNSUCCESSFUL REFUGEES WHO DO OR DO NOT KNON WHERE TO GO FOR MARRIAGE PROBLEMS

Response

$$
\frac{\text { Viet }}{N=28} \cdot \frac{\text { Successful }}{\frac{\text { Cam }}{N=5}} \frac{\text { Lao }}{N=10}
$$

$$
\frac{\text { Viet }}{N=23} \frac{\text { Unsuccessful }}{\frac{\text { Cam }}{N=5} \quad \frac{L a O}{N=7}}
$$

Yes

No

No response
$6(21 \%)$ $21(75 \%)$ $1(4)$
$4(17 \%) \quad 2(40 \%) \quad 3(43 \%)$ $13(75 \%) \quad 1(20 \%) \quad 4(57 \%)$ $6(26) \quad 2(40)$ 
DISTRIBUTION OF SUCCESSFUL AND UNSUCCESSFUL REFUGEES WHO DO OR DO NOT KNOW WHERE TO GO FOR WELFARE PROBLEMS

$\underline{\text { Response }}$

$$
\begin{aligned}
& \frac{\text { Viet }}{\mathrm{N}=28} \frac{\text { Successful }}{\frac{\text { Cam }}{\mathrm{N}=5}} \quad \frac{\text { Lao }}{\mathrm{N}=10} \quad \frac{\text { Viet }}{\mathrm{N}=23} \quad \frac{\text { Unsuccessful }}{\mathrm{N}=5} \quad \frac{\text { Lao }}{\mathrm{N}=7} \\
& \begin{array}{lcccccc}
\text { Yes } & 24(86 \%) & 5(100 \%) & 8(80 \%) & 9(39 \%) & 2(40 \%) & 5(71 \%) \\
\text { No } & 4(14) & - & 2(20) & 11(48) & 2(40) & 2(29) \\
\text { No response } & - & - & - & 3(13) & 1(20) & -
\end{array}
\end{aligned}
$$

\section{TABLE XXXV}

DISTRIBUTION OF SUCCESSFUL AND UNSUCCESSFUL REFUGEES WHO DO OR DO NOT KNOW WHERE TO GO FOR EMPLOYMENT PROBLEMS

Response

$$
\frac{\text { Viet }}{\mathrm{N}=28} \frac{\frac{\text { Successful }}{\mathrm{N}=5}}{\frac{\mathrm{Cam}}{\mathrm{N}=10}} \quad \frac{\text { Viet }}{\mathrm{N}=23} \frac{\frac{\text { Unsuccessful }}{\mathrm{N}=5}}{\mathrm{LaO}}
$$

$\begin{array}{lcclllc}\text { Yes } & 27(96 \%) & 3(60 \%) & 6(60 \%) & 11(48 \%) & 1(20 \%) & 2(29 \%) \\ \text { No } & 1(4) & 2(40) & 4(40) & 10(43) & 2(40) & 5(71) \\ \text { No response } & - & - & - & 2(9) & 2(40) & -\end{array}$

\section{TABLE $\quad X X X V I$}

DISTRIBUTION OF SUCCESSFUL AND UNSUCCESSFUL REFUGEES

WHO DO OR DO NOT KNOW WHERE TO GO FOR

POLITICAL PROBLEMS

Response

Yes

\begin{tabular}{|c|c|c|c|c|c|}
\hline \multicolumn{3}{|c|}{ Successful } & \multicolumn{3}{|c|}{ Unsuccessful } \\
\hline$\frac{V \text { iet }}{N=28}$ & $\frac{\mathrm{Cam}}{\mathrm{N}=5}$ & $\frac{\text { Lao }}{N=10}$ & $\frac{\text { Viet }}{\mathrm{N}=23}$ & $\frac{C a m}{N=5}$ & $\frac{L a O}{N=7}$ \\
\hline & & & & - & \\
\hline & (ou & & & $3(6$ & \\
\hline & - & - & $2(9)$ & $2(40)$ & \\
\hline
\end{tabular}

No.

No response 
TABLE XXXVII

DISTRIBUTION OF SUCCESSFUL AND UNSUCCESSFUL REFUGEES

WHO DO OR DO NOT KNOW WHERE TO GO FOR SCHOOL PROBLEMS

Response

$\begin{array}{lcccccc}\text { Yes } & 18(64 \%) & 4(80 \%) & 7(70 \%) & 8(35 \%) & 2(40 \%) & 3(43 \%) \\ \text { No } & 10(36) & - & 3(30) & 12(52) & 1(20) & 4(57) \\ \text { No response } & - & 1(20) & - & 3(13) & 2(40) & -\end{array}$

TABLE XXXVIII

DISTRIBUTION OF SUCCESSFUL AND UNSUCCESSFUL REFUGEES WHO FEEL SOCIAL SERVICE WORKERS UNDERSTAND THEIR PROBLEMS AND HELP THEM

Response

\begin{tabular}{|c|c|c|c|c|c|}
\hline \multicolumn{3}{|c|}{ Successful } & \multicolumn{3}{|c|}{ Unsuccessful } \\
\hline$\frac{\text { Viet }}{\mathrm{N}=28}$ & $\frac{\mathrm{Cam}}{\mathrm{N}=5}$ & $\frac{\mathrm{LaO}}{\mathrm{N}=10}$ & $\frac{\text { Viet }}{\mathrm{N}=23}$ & $\frac{\mathrm{Cam}}{\mathrm{N}=5}$ & $\frac{\mathrm{LaO}}{\mathrm{N}=7}$ \\
\hline . & $2(40 \%)$ & $4(40 \%)$ & $1(4$ & $2(40 \%)$ & $5(71 \%)$ \\
\hline $3(20)$ & $1(20)$ & $3(30)$ & $16(20)$ & $2(40)$ & - \\
\hline $4(14)$ & $2(40)$ & $3(30)$ & $6(26)$ & $1(20)$ & $2(29)$ \\
\hline
\end{tabular}

TABLE XXXIX

DISTRIBUTION OF SUCCESSFUL AND UNSUCCESSFUL REFUGEES

WHO FEEL SOCIAL SERVICE WORKERS

TREAT THEM RESPECTFULLY

Response

$$
\frac{\text { Viet }}{\mathrm{N}=28} \frac{\frac{\text { Successful }}{\mathrm{N}=5}}{\frac{\mathrm{Cam}}{\mathrm{N}=10}} \frac{\text { Viet }}{\mathrm{N}=23} \frac{\text { Unsuccessful }}{\frac{\text { Cam }}{\mathrm{N}=5}} \quad \frac{\mathrm{LaO}}{\mathrm{N}=7}
$$

Yes

No

No response $\begin{array}{llllll}16(57 \%) & 1(20 \%) & 6(60 \%) & 9(39 \%) & 2(40 \%) & 5(71 \%)\end{array}$

$\begin{array}{llllll}4(14) & 1(20) & 3(30) & 10(43) & 1(20) & -\end{array}$

$\begin{array}{lllll}8(29) & 3(60) & 1(10) & 4(18) & 2(40)\end{array}$ 
TABLE XL

DISTRIBUTION OF SUCCESSFUL AND UNSUCCESSFUL REFUGEES WHO FEEL THEY DON'T HAVE TO WAIT TOO LONG FOR SERVICES

\begin{tabular}{|c|c|c|c|c|c|c|}
\hline \multirow[t]{2}{*}{ Response } & \multicolumn{3}{|c|}{ Successful } & \multicolumn{3}{|c|}{ Unsuccessful } \\
\hline & $\frac{\text { Viet }}{\mathrm{N}=28}$ & $\frac{\text { Cam }}{\mathrm{N}=5}$ & $\frac{\text { Lao }}{\mathrm{N}=10}$ & $\frac{\text { Viet }}{\mathrm{N}=23}$ & $\frac{\mathrm{Cam}}{\mathrm{N}=5}$ & $\frac{\mathrm{Lao}}{\mathrm{N}=7}$ \\
\hline Yes & $12(43 \%)$ & - & $5(50 \%)$ & $6(26 \%)$ & $2(40 \%)$ & $4(57 \%)$ \\
\hline No & $7(25)$ & $1(20 \%)$ & $5(50)$ & $8(35)$ & $1(20)$ & $2(29)$ \\
\hline No response & $9(32)$ & $4(80)$ & - & $9(39)$ & $2(40)$ & $1(14)$ \\
\hline
\end{tabular}

TABLE XLI

DISTRIBUTION OF SUCCESSFUL AND UNSUCCESSFUL REFUGEES WHO HAVE FOUND PLACES TO LIVE VIA SOCIAI SERVICE AGENCIES

Response

$$
\frac{\text { Viet }}{\mathrm{N}=28} \frac{\frac{\text { Successfu1 }}{\mathrm{N}=5}}{\frac{\text { Cam }}{\mathrm{N}=10}} \quad \frac{\text { Viet }}{\mathrm{N}=23} \frac{\text { Unsuccessfu1 }}{\frac{\text { Cam }}{\mathrm{N}=5}} \frac{\text { Lao }}{\mathrm{N}=7}
$$

$\begin{array}{lllllll}\text { Yes } & 6(21 \%) & 1(20 \%) & 6(60 \%) & 7(30 \%) & 1(20 \%) & 5(71 \%) \\ \text { No } & 16(57) & 1(20) & 3(30) & 9(40) & 2(40) & 1(14) \\ \text { No response } & 6(21) & 3(60) & 1(10) & 7(30) & 2(40) & 1(14)\end{array}$

\section{TABLE XIII}

DISTRIBUTION OF SUCCESSFUL AND UNSUCCESSFUL REFUGEES WHO HAVE FOUND JOBS VIA SOCIAL SERVICE AGENCIES

\begin{tabular}{|c|c|c|c|c|c|c|}
\hline \multirow{2}{*}{ Response } & \multicolumn{3}{|c|}{ Successful } & \multicolumn{3}{|c|}{ Unsuccessfu1 } \\
\hline & $\frac{\text { Viet }}{\mathrm{N}=28}$ & $\frac{\mathrm{Cam}}{\mathrm{N}=5}$ & $\frac{\mathrm{LaO}}{\mathrm{N}=10}$ & $\frac{\text { Viet }}{\mathrm{N}=23}$ & $\frac{\mathrm{Cam}}{\mathrm{N}=5}$ & $\frac{\mathrm{LaO}}{\mathrm{N}=7}$ \\
\hline es & $15(54 \%)$ & $I(20 \%)$ & $2(20 \%)$ & - & $2(40 \%)$ & $6(86 \%)$ \\
\hline & $5(17)$ & $1(20)$ & $6(60)$ & $12(52 \%)$ & $I(20)$ & $1(14)$ \\
\hline No response & $8(29)$ & $3(60)$ & $2(20)$ & $11(48)$ & $2(40)$ & - \\
\hline
\end{tabular}




\section{TABLE XIIII}

DISTRIBUTION OF SUCCESSFUL AND UNSUCCESSFUL REFUGEES WHO HAVE OR HAVE NOT ENCOUNTERED LANGUAGE AND COMMUNICATION PROBLEMS WITH SOCIAL AGENCIES

$\underline{\text { Response }}$

$\begin{array}{llllllc}\text { Yes } & 12(43 \%) & 1(20 \%) & 6(60 \% 0 & 12(52 \%) & 3(60 \%) & 5(71 \%) \\ \text { No } & 11(39) & 3(60) & 3(30) & 6(26) & 1(20) & 2(29) \\ \text { No response } & 5(18) & 1(20) & 1(10) & 5(22) & 1(20) & -\end{array}$

\section{TABLE XIIV}

DISTRIBUTION OF SUCCESSFUL AND UNSUCCESSFUL REFUGEES WHO HAVE ENCOUNTERED CULTURAL MISUNDERSTANDINGS

\section{WITH SOCIAL SERVICE AGENCIES}

Response

$$
\frac{\text { Viet }}{N=28} \frac{\frac{\text { Successful }}{N=5}}{\frac{\text { Cam }}{N=10}} \quad \frac{\text { Viet }}{N=23} \quad \frac{\text { Unsuccessful }}{N=5} \quad \frac{\text { Lam }}{N=7}
$$

Yes

No

No response

$\begin{array}{llllll}10(36 \%) & 1(20 \%) & 6(60 \%) & 11(48 \%) & 4(80 \%) & 5(71 \%) \\ 9(32) & 2(40) & 3(30) & 5(22) & - & 1(14) \\ 9(32) & 2(40) & 1(10) & 8(35) & 1(20) & 1(14)\end{array}$

\section{TABLE XLV}

DISTRIBUTION OF SUCCESSFUL AND UNSUCCESSFUL REFUGEES WHO HAVE ENCOUNTERED OTHER PROBLEMS WITH SOCIAL SERVICE AGENCIES

Response

$$
\frac{\text { Viet }}{N=28} \frac{\text { Successfu1 }}{\frac{\text { Cam }}{N=5}} \quad \frac{\text { Lao }}{N=10} \quad \frac{\text { Viet }}{N=23} \quad \frac{\text { Unsuccessfu1 }}{\frac{\text { Cam }}{N=5}} \frac{\text { Lao }}{N=7}
$$

Yes

No

$2(7 \%)$

$4(14)$

No response
$1(10 \%) \quad-\quad 2(40 \%) \quad 3(43 \%)$

$\begin{array}{lllll}1(20) & 3(30) & 7(30 \%) & 1(20) & 3(43)\end{array}$

$\begin{array}{lllll}4(80) & 6(60) & 16(70) & 2(40) & 1(14)\end{array}$ 
TABLE XIVI

DISTRIBUTION OF SUCCESSFUL AND UNSUCCESSFUL REFUGEES

WHO FEEL RACIAL DISCRIMINATION HAS

AFFECTED THEIR RESETTLEMENT

Response

$\frac{\text { Viet }}{\mathrm{N}=28} \frac{\text { Successful }}{\frac{\text { Cam }}{N=5}} \quad \frac{\text { Lao }}{\mathrm{N}=10}$

$\frac{\text { Unsuccessful }}{\mathrm{N}=23} \quad \frac{\mathrm{Cam}}{\mathrm{N}=5} \quad \frac{\mathrm{LaO}}{\mathrm{N}=7}$

$\begin{array}{lllllll}\text { Always affected } & 10(36 \%) & - & 3(30 \%) & 3(13 \%) & - & 1(14 \%) \\ \text { Almost always affected } & 1(4) & - & 3(30) & 5(22) & - & 1(14) \\ \text { Sometimes affected } & 16(57) & 3(60 \%) & 3(30) & 11(48) & 4(80 \%) & 2(29) \\ \text { Never affected } & 1(4) & - & - & - & - & 2(29) \\ \text { No response } & - & 2(40) & 1(10) & 4(18) & 1(20) & 1(14)\end{array}$

TABLE XIVII

DISTRIBUTION OF SUCCESSFUL AND UNSUCCESSFUL REFUGEES WHO FEEL THEY HAVE COME UP AGAINST PRESSURE IN TAKING A JOB

Response

$\frac{\text { Viet }}{\mathrm{N}=28} \frac{\frac{\text { Successful }}{\mathrm{N}=5}}{\frac{\mathrm{Cam}}{\mathrm{N}=10}} \quad \frac{\text { Uiet }}{\mathrm{N}=23} \quad \frac{\text { Cam }}{\mathrm{N}=5} \quad \frac{\mathrm{LaO}}{\mathrm{N}=7}$

$\begin{array}{lllllll}\text { Almost no pressure } & 2(7 \%) & 2(40 \%) & - & 2(9 \%) & - & 1(14 \%) \\ \text { Little pressure } & 2(7) & - & 3(30) & 5(22) & 1(20) & 1(14) \\ \text { Some pressure } & 16(57) & 1(20) & 3(30) & 7(30) & - & - \\ \text { Much pressure } & 6(21) & 1(20) & 4(40) & 7(30) & 2(40) & 1(14) \\ \text { Very much pressure } & - & - & - & - & 1(20) & 4(57) \\ \text { No response } & 2(7) & 1(20) & - & 2(9) & 1(20) & -\end{array}$

TABLE XIVIII

DISTRIBUTION OF SUCCESSFUL AND UNSUCCESSFUL REFUGEES

WHO FEEL THEY HAVE ATTAINED SUCCESS IN THEIR NEW LIFE

Response

$\frac{\text { Viet }}{N=28} \quad \frac{\text { Successful }}{N=5}, \frac{\text { Lao }}{N=10} \quad \frac{\text { Viet }}{N=23} \quad \frac{\text { Cam }}{N=5} \quad \frac{\text { Lao }}{N=7}$

$\begin{array}{llllllc}\text { Very much success } & 6(21 \%) & 1(20 \%) & 1(10 \%) & 1(4 \%) & - & - \\ \text { Much success } & 1(4) & 2(40) & 1(10) & 2(8) & - & - \\ \text { Some success } & 12(42) & 1(20) & 4(40) & 5(22) & 3(60 \%) & 1(14 \%) \\ \text { Littel success } & 5(18) & - & 3(30) & 5(22) & 2(40) & 1(14) \\ \text { Very little success } & 3(11) & - & - & 5(22) & - & 5(71) \\ \text { No response } & 1(4) & 1(20) & 1(10) & 5(22) & - & -\end{array}$

